Portland State University

PDXScholar

4-30-2004

\title{
The Wilderness Problem: A Narrative of Contested Landscapes in San Juan County, Utah
}

David Banis

Portland State University

Follow this and additional works at: https://pdxscholar.library.pdx.edu/open_access_etds

Part of the Geography Commons Let us know how access to this document benefits you.

\section{Recommended Citation}

Banis, David, "The Wilderness Problem: A Narrative of Contested Landscapes in San Juan County, Utah" (2004). Dissertations and Theses. Paper 1972.

https://doi.org/10.15760/etd.1971

This Thesis is brought to you for free and open access. It has been accepted for inclusion in Dissertations and Theses by an authorized administrator of PDXScholar. Please contact us if we can make this document more accessible: pdxscholar@pdx.edu. 


\section{THESIS APPROVAL}

The abstract and thesis of David Banis for the Master of Sctence in Geography were presented April 30, 2004 and accepted by the thesis committee and the department.

COMMITTEE APPROVALS:

Barbara Brower, Chair

Joff Poracsky

Martha Works

Connie Ozawa

Representative of the Office of Graduate Studies

DEPARTMENT APPROVAL:

Martha Works, Acting Chair

Department of Geography 


\begin{abstract}
An abstract of the thesis of David Banis for the Master of Science in Geography presented April 30, 2004.
\end{abstract}

Title: The Wildernęss Problem: A Narrative of Contested Landscapes in San Juan County, Utah

Wilderness preservation has been at the center of debates about public land policy for almost half a century, and nowhere has the controversy been more intractable than in Utah. Despite its vast expanses of unsettled and undeveloped red rock desert, managed primarily by the Bureau of Land Management (BLM), Utah has less designated wilderness than in any other state in the West. In this study, I focus on San Juan County in southeast Utah to study the conflict over the designation of wilderness. The controversy pits local residents and state politicians against state and national environmental groups, with the BLM shifting positions in between.

I analyze and interpret the wilderness debate from three different perspectives. The first explores the history of the Utah wilderness debate from the first BLM wilderness inventory in the 1970 's through its re-inventory in the 1990 's. I examine the influence of national, regional, and local forces such as institutional change within the BLM, in-fighting among Utah-based environmental interest groups, and the sagebrush rebellion and county supremacy movements. The second perspective incorporates the spatial analytical techniques of geographical information systems to provide a relativelv obiective view of landscape characteristics used to define 
wilderness. I interpret the landscape as a continuum of varying degrees of wildness, a product of inherent naturalness and the influences of human impacts. Lastly, I examine the personal views of the meaning of wilderness through the words of actual participants in the debate. In an analysis of the statements of both county residents as well as the Southern Utah Wilderness Alliance, I explore the mental images and ideas that influence the ways in which people value and understand the desert environment. 


\section{TABLE OF CONTENTS}

LIST OF TABLES

LIST OF FIGURES

ACRONYMS

INTRODUCTION

ENCHANTED WILDERNESS

The BLM Lands of Utah

The Southeast Corner

Wilderness Study Areas and Re-inventory Study Units

The Desert

CUSTOM AND CULTURE

Frontier Legacy, Western Paradox

Latter-Day Saints.

On the Outskirts of Mormon Country .

CONSERVATION

Acts of National Contrition

The Idea of Wilderness.

Wilderness in the Wilderness Act.

THE BLM WILDERNESS INVENTORIES: A HISTORY

The "Bureau of Livestock and Mining" Looks for Wilderness.

Backlash: Sagebrush Rebellion and the Birth of Uncompromising Advocacy .... 
TABLE OF CONTENTS (CONTINUED)

PAGE

The Election of a Republican Congress: A Door Opens .......... 83

The Greening of the BLM. . . . . . . . . $8 \ldots \ldots \ldots \ldots \ldots$

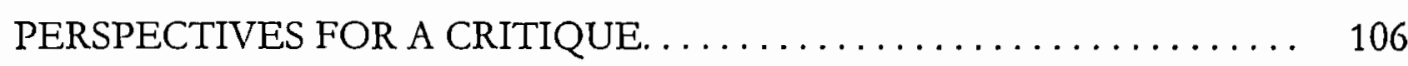

The View from a Distance. . . . . . . . 106

The View from Somewhere. . . . . . . . . . . . 123

THE WILDERNESS PROBLEM: WHOSE CANYONLANDS? . . . . . . . 143

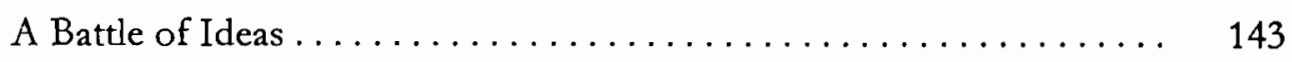

Rethinking the Approach ................... 148

The Next Sagebrush Rebellion. . . . . . . . . . . . . . . 151

New Concepts for Public Lands. . . . . . . . . . . . . . . 153

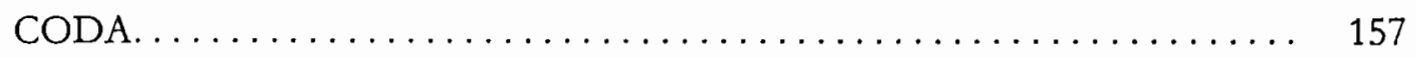

ENDNOTES. .............................. 162

REFERENCES. . . . . . . . . . . . . . . . . . . . . . 164

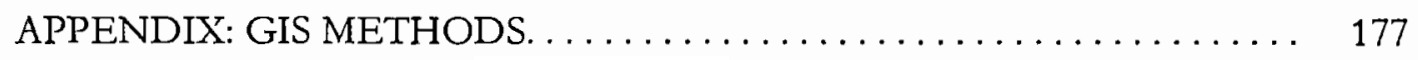




\section{LIST OF TABLES}

TABLE

PAGE

I Wilderness Areas by Land Management Agency ......... 52

II Wilderness Study Areas in San Juan County:

Characteristics .................... 78

III Wilderness Study Areas in San Juan County:

Potential Multiple Uses ................... 79

IV Re-inventory Study Units in San Juan County:

BLM Findings . . . . . . . . . . . . . . 100

V Re-inventory Study Units in San Juan County:

Characteristics ...................... 101

VI BLM Wilderness Statistics ..................... 105

VII Arguments against Wilderness Designation from the San

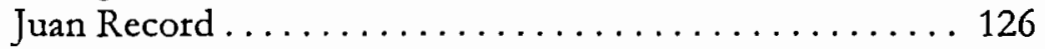




\section{[OF FIGURES}

1. Federal Lands in the Western United States ............. 3

2. Wilderness Areas in the Western United States ........... 4

3. The Colorado Plateau $\ldots \ldots \ldots \ldots \ldots \ldots \ldots \ldots \ldots \ldots .10$

4. BLM Lands under Study for Wilderness Designation in Utah . . . 12

5. San Juan County, Utah................... 14

6. Wilderness Study Areas and Re-inventory Study Units in San Juan County $\ldots \ldots \ldots \ldots \ldots \ldots \ldots \ldots \ldots \ldots \ldots \ldots \ldots \ldots \ldots$

7. Wilderness Designated by Year $\ldots \ldots \ldots \ldots \ldots \ldots \ldots \ldots \ldots$

8. Utah Wilderness Proposals: $1985 \ldots \ldots \ldots \ldots \ldots \ldots \ldots \ldots$

9. San Juan County Wilderness Proposals: $1985 \ldots \ldots \ldots \ldots \ldots .71$

10. Utah Wilderness Proposals: $1990 \ldots \ldots \ldots \ldots \ldots \ldots \ldots \ldots$

11. San Juan County Wilderness Proposals: $1990 \ldots \ldots \ldots$. . . . . 82

12. Utah Wilderness Proposals: $1995 \ldots \ldots \ldots \ldots \ldots \ldots \ldots \ldots . \ldots 7$

13. San Juan County Wilderness Proposals: $1995 \ldots \ldots \ldots \ldots \ldots$

14. Utah Wilderness Proposals: $2000 \ldots \ldots \ldots \ldots \ldots \ldots \ldots$

15. San Juan County Wilderness Proposals: $2000 \ldots \ldots \ldots \ldots \ldots$

16. Landscape Measures: Wilderness Characteristics .......... 111

17. Wilderness Characteristics for San Juan County .......... 112

18. Landscape Measures: Multiple Use Properties . . . . . . . . . 115

19. Wildness Continuum for San Juan County ........... 116 


\section{LIST OF FIGURES (CONTINUED)}

$\begin{array}{lll}\text { FIGURE PAGE } & \text { PAR }\end{array}$

20. Wildness Continuum and Wilderness Proposals for

San Juan County .................. 118

21. Distribution of Inventory Units in the Wildness Continuum .. 119 
ACRONYMS

ACEC ......... Area of Critical Environmental Concern

BLM . . . . . . . Bureau of Land Management

DEIS ......... Draft Environmental Impact Statement

DEM ........ Digital Elevation Model

DOI ......... Department of the Interior

EIS . . . . . . . . Environmental Impact Statement

EPA ......... Environmental Protection Agency

FLPMA ........ Federal Land Policy Management Act

GIS ......... Geographic Information Systems

IBLA ......... Interior Land Appeals Board

LULC ......... Land Use/Land Cover

NCA ........ National Conservation Area

NEPA ........ National Environmental Policy Act

NPCA ........ National Parks Conservation Association

OHV ........ Off-Highway Vehicle

RSU . . . . . . . Re-inventory Study Unit

SULU ......... Southeast Utah Land Users

SUWA ........ Southern Utah Wilderness Alliance

UAGRC ........ Utah Automated Geographic Reference Center

UPLMUC ........ Utah Public Lands Multiple Use Coalition 


\section{ACRONYMS (CONTINUED)}

USGS .......... United States Geological Survey

UWA ......... Utah Wilderness Alliance

UWC ........ Utah Wilderness Coalition

WSA ......... Wilderness Study Area 


\section{INTRODUCTION}

The Colorado Plateau in Southern Utah is an extraordinary place, a semi-arid land of steep-walled red rock canyons, sagebrush mesas, and pinyon and juniper woodlands. With its architecture of arches, domes, spires, alcoves, towers, bridges, and monuments, the work of erosion is evident everywhere. Some of these geological wonders are protected in famous national parks such as Arches, Zion, and Bryce Canyon. But these protected areas are just islands in a sea of mostly undeveloped federal land managed for multiple use by the Bureau of Land Management (BLM). Increased demands on the use of public lands have made these former "lands that no one wanted" of interest to many.

Extraordinary as well is the conflict over this landscape, one that has come to epitomize the intractable environmental controversy. The debate focuses not only on which if any public lands have wilderness characteristics, but just as importantly on whether those lands should be officially designated as wilderness, with land use severely restricted. Wilderness issues have been at the center of debates about public land policy for more than half a century, but BLM lands were not even under consideration as wilderness until 1976. The Federal Land Policy and Management Act of 1976 (FLPMA) mandated that the BLM evaluate whether the lands it managed had the potential for wilderness designation. Ever since the initial inventory results for Utah were made public in 1979 , controversy has raged over which lands were included and excluded. The debate became national with appeals, hearings, and legislative 
proposals long before the BLM even made its limited recommendation for wilderness designation in 1991. In an attempt to resolve the issue, Secretary of the Interior Bruce Babbitt in 1996 ordered the BLM to conduct a second wilderness review of certain public lands in Utah. In Babbitt's words "an important reason for this stalemate is that the various interests involved are so far apart on the threshold, fundamental issue of how much BLM land has wilderness characteristics in the state" (quoted in BLM 1999, vii). When this te-inventory was completed in 1999 , much land with wilderness character was found where it did not exist twenty years earlier.

Yet 28 years after the passage of FLPMA, nothing has really changed in Utah. Sixty-four percent of the state is federal land, the third highest percentage of the eleven western states with substantial federal land holdings (Figure 1). Of these states, Utah holds the distinction of having the least land designated as wilderness (Figure 2). None of this wilderness is on BLM lands, which comprise almost two thirds of the state's federal lands. For this reason, as well as for the uniqueness of its desert landscapes, Utah holds a prominent place in the wilderness debate.

To understand the Utah conflict over wilderness, one must consider how separate threads of history, public policy, and cultural and environmental values are interwoven. In its study of place and space, geography is uniquely capable of tying these threads together to illustrate patterns. Here, the theoretical framework developed by Robert Sack (1997) serves as a guide. For Sack, the study of place is primaty, because place serves as a nexus where the three basic forces that influence us overlap: nature, social relations, and ideas or meaning. The study of place allows one to see the 
Figure 1. Federal Lands in the Western United States

Forest Service

Fish and Wildlife Service

National Park Service

Burcau of Land Management

Bureau of Indian Affairs

Other
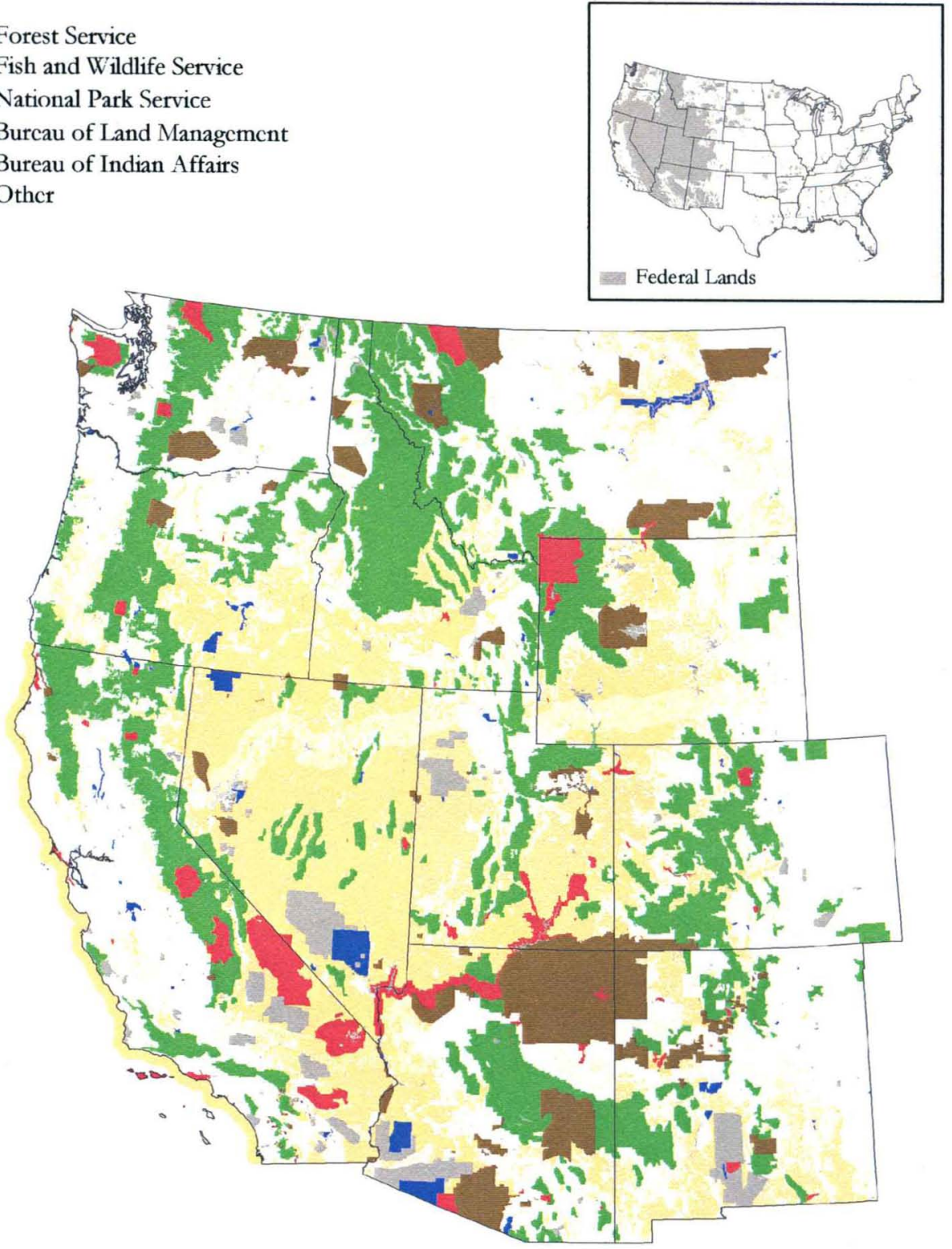
Figure 2. Wilderness Areas in the Western United States

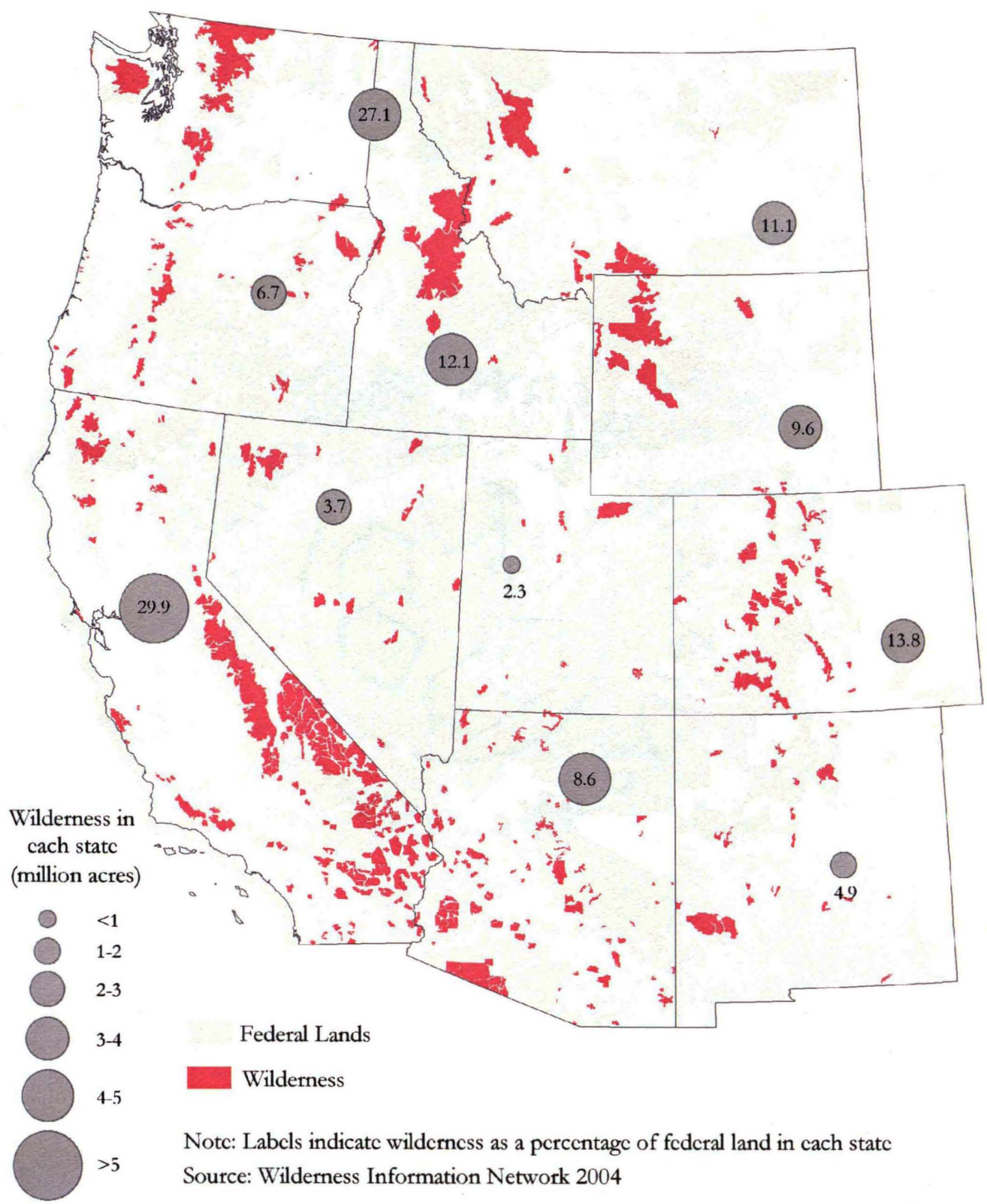


effects of all three forces separately as well as their interaction. Just as importandy, place also exerts a force of its own that in tum affects social action, natural phenomena, and meanings. It almost goes without saying that natural phenomena at play are determined for the most part by place, in this case a high elevation desert landscape, not forests or mountains. But place also affects which social forces are most relevant, for instance whether economic or social use of wilderness shapes the laws and governmental management decisions governing land use. Place also invokes a range of ideas and meanings that may be particular to canyonlands of southern Utah, or the West in general, or even to the right use of the natural world.

Place can also be viewed from different perspectives. These vary from the theoretically impartial view, a view from nowhere, to a perspective anchored in place, a view from somewhere (Nagel 1986). A complete understartding of place incorporates both subjective and objective reality, the personal and the impersonal, values and facts. J. Nicholas Entrikin (1991) argues that place cannot be adequately understood by only the decentered objective view, where place becomes just a location or a set of general relationships, or by the centered subjective view, where place has a stticdy personal meaning. Place should be viewed from some point in between.

Studies that are removed from place often focus on one of these three forces at the expense of the others. Rudzitis (1996) assesses wilderness management policy in the American West in light of demographic and economic changes. Two recent books analyze the wilderness debate in Utah as a set of political, economic, and social forces acting at the scale of the entire state (Goodman and McCool 1999), or as a history of 
advocacy and resistance (Watkins 2000). This study is more in line with work such as that of Thomas and Geraldine Vale (1989) in Western Images, Western Landscapes, which explores the ways that mental images influence people's interaction with the environment, and how the physical environment itself influences or modifies those mental images. The subjective and objective interact to create a total view of the landscape; societal values and ideology and images are manifested in the landscape, and at the same time, the natural systems limit the possibilities available. In a related fashion, Wyckoff and Hansen (1991) use the case study of one valley in Montana to illustrate how local and national forces, instead of meanings and ideas, have interacted with and influenced the environment over time.

San Juan County, located in the southeast corner of the state, will serve as a case study to describe and analyze this conflict over wilderness in Utah. San Juan County lies at the geographic center of the Colorado Plateau, and is home to its share of the potential wilderness in Utah. Here, ranching and mining have been the traditional uses of public lands, and the local government actively resists wilderness designation. The Southern Utah Wilderness Alliance, Utah's largest environmental group, monitors their actions from one of its two field offices outside of Salt Lake City. The Utah BLM has made this southeast corner of the state a test case for its new regional approach to analysis of the wilderness re-inventory findings. Although no single region incorporates all the various elements of the statewide wilderness debate, San Juan County makes a fine microcosm. 
My study starts in 1976 with the passage of FLPMA and culminates with the Utah BLM wilderness re-inventory, but its roots lie in the events and ideas of the past, and also in the nature of the land itself. For that reason, I construct a substantial background that provides context for more recent events. In the first section I introduce the place, San Juan County, and describe the potential wilderness lands that are at the center of the debate. This section concludes with a discussion of the changing perceptions of the desert and its aesthetic appreciation. Short histories of the two distinct cultures involved in the debate follow. I introduce a short history of San Juan County with a discussion of the meaning of western "custom and culture" and the influence of Mormonism on Utah and the surrounding region. Although they are only one part of the county's history, the focus here is on the Mormon settlers, those who are the main advocates against wilderness designation. The second history is of the advocacy within the conservation movement for the creation of wilderness, culminating with the passage of the Wilderness Act. Integral to this story is how perceptions of meanings associated with wilderness have changed over time, and the subsequent section explores this very slippery concept. A discussion of the varied relationships of humans to nature provides the broadest context for this study.

After establishing this background, I analyze and interpret the wilderness debate in San Juan County from three different perspectives. The first is an historical narrative of the Utah wilderness debate from the first BLM inventory in the 1970's through the re-inventory in the 1990's. In this narrative, I explore the influence of national, regional, and local forces such as institutional change within the BLM, in- 
fighting among Utah-based environmental interest groups, and the sagebrush rebellion and county supremacy movements. The second perspective incorporates the spatial analytical techniques of geographical information systems (GIS) to provide a relatively objective view of landscape characteristics used to define wilderness. I interpret the landscape as a continuum or surface of varying degrees of wildness, a product of inherent naturalness and the influences of human impacts. Lastly, I examine the personal views of the meaning of wilderness through the words of actual participants in the debate. Here, in an analysis of the statements of both county residents as well as the Southern Utah Wilderness Alliance, I explore the mental images and ideas that influence the ways in which people value and understand the desert environment.

My goal in this study is to build layers of place. These layers emerge out of views of place from different perspectives, and from changes through time. They represent multiple meanings, values, and interpretations. Each layer of place can be studied separately, or overlayed and analyzed with others to explore the interaction of the forces of nature, social relations, and meaning. What local people say about wilderness, what arguments environmentalists use to support wilderness, and how the BLM analyzes potential wilderness can be compared with the nature of the land itself. This type of interpretation can identify often hidden patterns with explanatory power particular to this region and to the wildemess issue. 


\section{ENCHANTED WILDERNESS}

"... the Colorado Plateau as a unit ... as an integral whole . . . as a distinct physiographic province... has not been recognized by more than a handful of visionary people as a world resource, a unique wilderness of true enchantment ... how many have been aware that the Colorado Plateau is the largest wild or near-wild province still remaining in the 48 contiguous states ..." (Roylance 1971)

The Colorado Plateau is a high elevation landscape of canyons, mesas, and escarpments. It is bounded by the Rocky Mountains to the north and east and the Basin and Range Province to the west and south (Figure 3). The Colorado River and its tributaries drain ninety percent of the land encompassed by the plateau, and cut labyrinths of canyons into the thick sedimentary strata. The Colorado Plateau is characterized by its remarkable erosional landforms, monoclinal structures, and mountains formed by igneous laccoliths. This unique and fragile desert land is home to much biodiversity captured in isolated niches created by an ever-changing landscape.

Centered in this Colorado Plateau province, southern Utah was the last area of the contiguous United States to be explored and mapped, and these lands remain one of the most isolated and least populated places of the country. Five national parks, an equal number of national monuments, and the enormous national recreation area at Lake Powell protect some of its geological wonders for tourists, but the majority of this vast land remains unvisited. As stunning and awe-inspiring as the landscape may be, it is difficult to approach in many ways. Even the Mormons, who saw the 
Figure 3. The Colorado Plateau

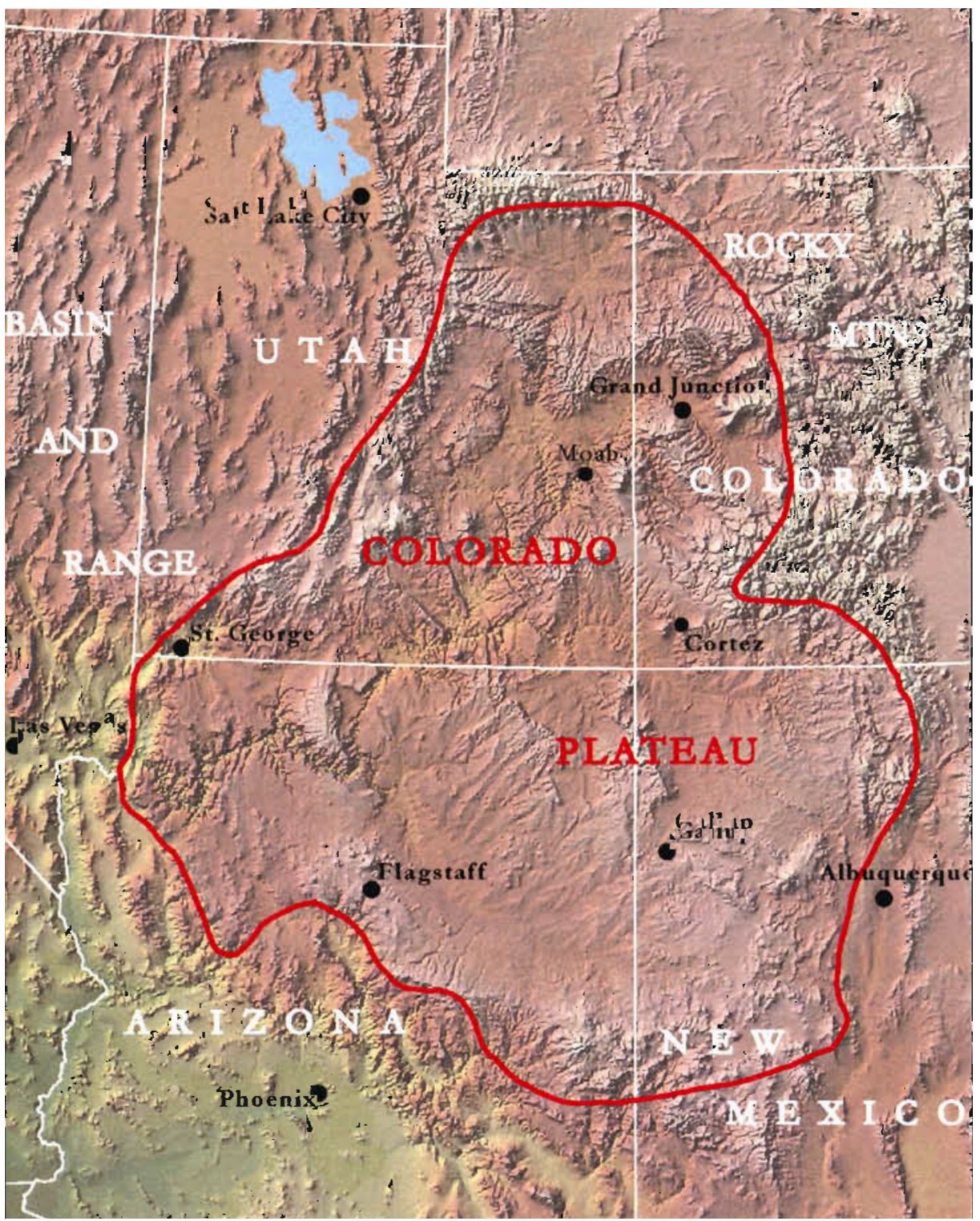


promised land in the desolate landscape of the Great Basin, viewed the lands of the Colorado Plateau as inhospitable territory. These incomparable lands, would-be wilderness, bear little resemblance to the mountain lands and forests that comprise most wilderness areas in the United States.

\section{$\underline{\text { The BLM Lands of Utah }}$}

The large majority of the BLM lands in Utah under consideration for wilderness designation are on the Colorado Plateau. Figure 4 displays their extent, stretching southwest from the Uinta Mountains on the Wyoming/Utah border to the Arizona border. Potential wilderness is found in the areas surrounding Zion and Bryce Canyon National Parks in the southwest, and in much of Escalante-Grand Staircase National Monument in the south central part of the state. The Henry Mountains and the canyons of the Dirty Devil River west of Glen Canyon National Recreation Area form another region of would-be wilderness. The San Rafael Swell in the east central part of the state contains potential wilderness lands closest to the Salt Lake City's urban areas. Portions of the San Rafael Swell have been proposed both as a national park and national monument in the past. In the northeast, the Book Cliffs and Desolation Canyon of the Green River, as well as lands surrounding Dinosaur National Monument, are also under consideration as wilderness. The remaining BLM lands considered for wilderness designation are found in the western desert in the Basin and Range province. 
Figure 4. BLM Lands Under Study for Wilderness Designation in Utah

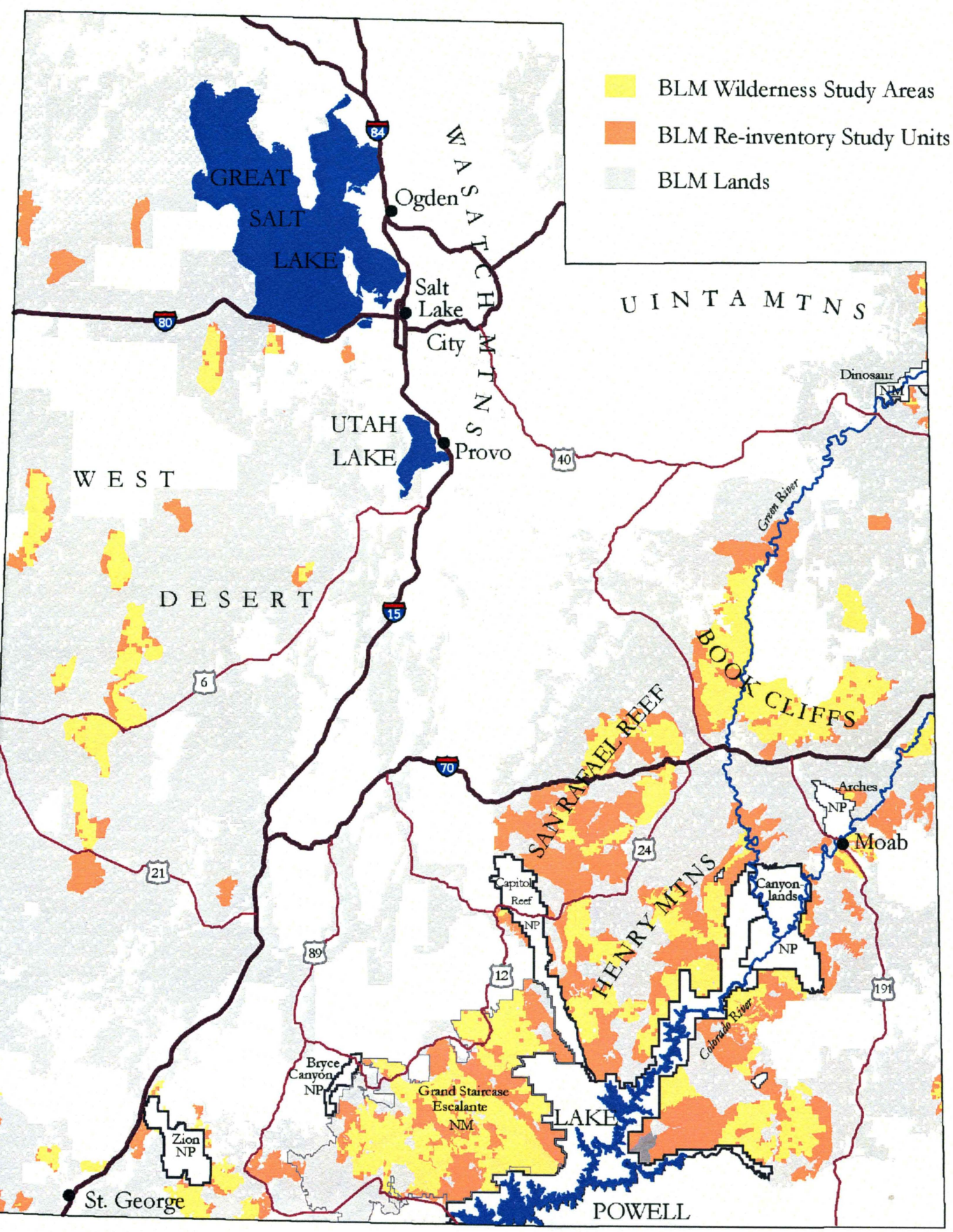


The geographic center of the Colorado Plateau is in the southeast comer of Utah, situated east of the Colorado River. This is where one finds San Juan County figure 5). Federal lands comprise 87 percent of the county, and 42 percent of those Lands are administered by the BLM. National Forests are located in the LaSal Mountains in the northeast, and the Abajo Mountains in the center of the county. The Ute Indian Reservation and the northern section of the Navajo Indian Reservation make up the county's southern quarter. Canyonlands National Park lies in the Northwest corner of the county, and similar canyon country extends beyond the park to the south and west on predominantly BLM-administered land. The area surrounding the reservoir of Lake Powell that fills Glen Canyon is managed by the National Park Service as a national recreation area.

Towns are strung out along Utah State Highway 191, the path of least resistance through this landscape. This eastern part of the county is subject to the most significant human impacts. The Great Sage Plain, mostly private land and the agricultural heart of the area, stretches east into Colorado. To the north of this plain is the still-active mining district of Lisbon Valley, and to the south the expansive Blanding Basin. The BLM land here is dissected by canyons, but less dramatically so than in the western part of the county. The Blanding Basin is home to Hovenweep National Monument and the largest oil field in Utah.

Lands under consideration for wilderness designation in the southeast corner of the state extend into Grand County to the north. These include the canyons to the 
Figure 5. San Juan County, Utah

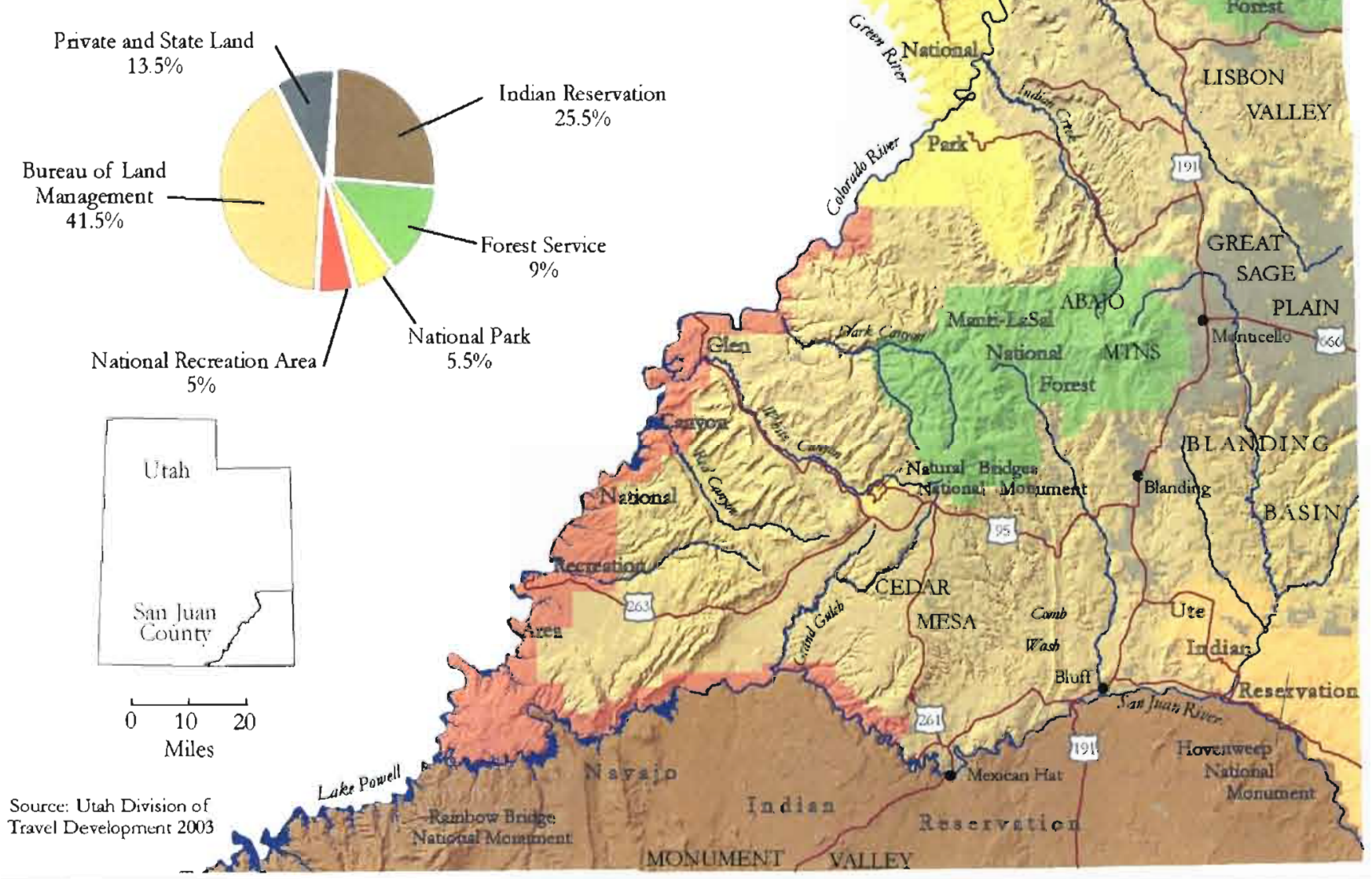


south and east of Arches National Park and the Behind the Rocks region between Moab and Canyonlands National Park.

\section{Wilderness Study Areas and Re-inventory Study Units}

Although no BLM lands are yet designated as wilderness in San Juan County, there are twelve wilderness study areas (WSAs) created after the original inventory, and twenty re-inventory study units (RSUs) for potential designation. (1) These BLM lands with would-be wilderness can be divided into five regions, as illustrated in Figure 6, and are described below.

Canyonlands. In the north along the Colorado and Green Rivers is the basin containing Canyonlands National Park, abutted by public lands to the east and south. The National Park Service has proposed expanding the size of Canyonlands to more than twice its current size, following physiographic boundaries instead of section lines. This expansion would incorporate BLM lands under consideration for wilderness designation, in addition to parts of Glen Canyon National Recreation Area. Action has yet to be taken by Congress on the proposal (NCPA 2004).

The Canyonlands basin contains three WSAs and four RSUs. Indian Creek is a small WSA contiguous with and east of the park. This stretch of Indian Creek is its lower reach after passing through quite heavily-used Lockhart Basin, which provides the only avenue of access to the Needles district of the park. The WSA is mostly slickrock except for riparian corridors in the many side canyons, and the surrounding 


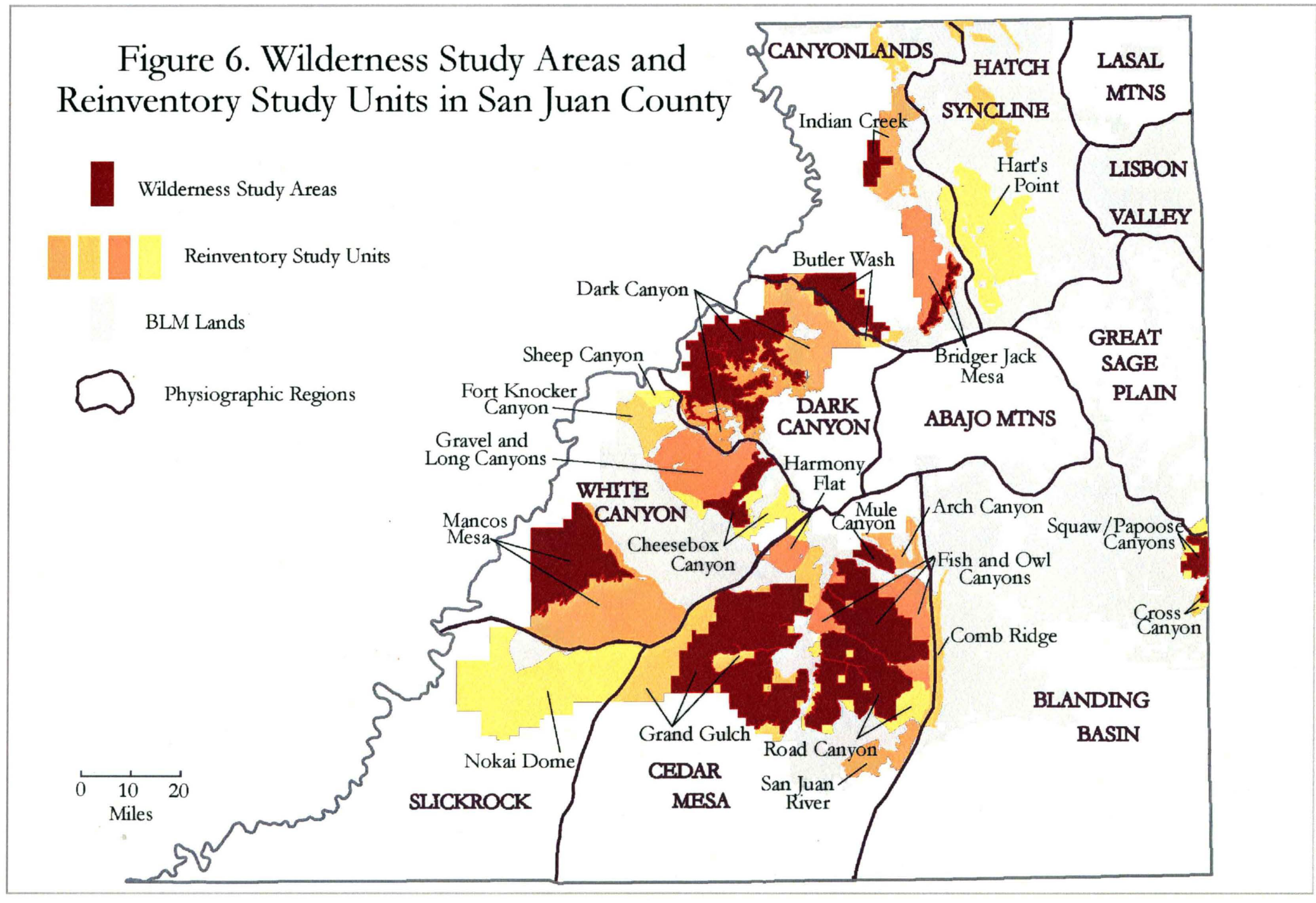


RSU lands are extensive desert shrub flatlands. Bridger Jack Mesa WSA, also located east of the park, is a prominent landmark noticeable on the approach to the Needles District. Approximately ten miles long and a mile wide, Bridger Jack Mesa is virtually inaccessible, and contains relict plant communities that have never been grazed. Similar mesas separate adjacent Lavender and Davis Canyons in an associated RSU. Farther east, the mesa of Hart's Point forms the southeastern edge of the Canyonlands basin along upper Indian Creek. Along with the associated canyon of Hart's Draw, Hart's Point forms an extensive RSU without an associated WSA. The last of the Canyonlands WSAs, Butler Wash is contiguous with the park and located to its south. Along with Salt Creek to its east, Butler Wash drains the southern highlands of the park basin. The colorful sandstone pinnacles and knobs of the WSA are similar to those of the Needles District of the park. The surrounding RSU is dominated by sagebrush parks that mark the start of the Dark Canyon region to the south.

The public lands east of Canyonlands National Park epitomize the multipleuse philosophy. A paved road winds past most of these potential wilderness areas, and a large cattle ranch, now managed by the Nature Conservancy, lies just outside the park boundary. Lockhart Basin is a popular off-highway vehicle (OHV) area and recently of interest for oil and gas development. Uranium mining scars are common, and Lavender Canyon was once the proposed home of a nuclear waste depository.

San Juan County contains sections of WSAs that are predominantly in neighboring Grand County, such as Behind the Rocks near Moab, and these areas are excluded from my study. Also excluded are the re-inventory lands in Hatch Wash 
which, although completely contained within San Juan County, are administered along with geographically similar surrounding areas by the BLM Moab field office.

Dark Canyon. Extensive plateaus cut by canyons as much as two thousand feet deep characterize the Dark Canyon region. Mesatop fingers explore viewpoints into seven different canyon systems including noteworthy Fable Valley. These canyons, which are south of Canyonlands National Park, drain to the west into Cataract Canyon of the Colorado River, in Glen Canyon National Recreation Area. The heavily wooded slopes of the upper teaches of Dark Canyon, responsible for its name, lie across the arbitrary boundary of the Manti-LaSal National Forest. These lands comprise the Dark-Canyon/Woodenshoe Wilderness, the only land so designated in the southeastern corner of Utah. The existing WSA boundary follows the canyon edges, convoluted in appearance on a map but very straightforward to see. Vegetation varies from Douglas fir and ponderosa pine at the upper elevations, to riparian zones in the canyon bottoms where one of the few perennial streams in the region runs through Dark Canyon.

The re-inventory lands under consideration here are expansive sagebrush plateaus with names like Beef Basin and Wild Cow Point. Not surprisingly, in these areas the boundaries are drawn around the impacts of cattle ranching. Even in one of the most isolated places in the lower 48 states, more than fifty miles of dirt road from the nearest highway, one finds corrals, watering ponds, and chainings in various states of recovery. (2) Comments in the trail register for Fable Valley mention cowpies as often as scenic wonders. Older human impacts are found in Ruin Park near Butler 
Wash in the form of scattered Anasazi towers and other structures usually found protected in national monuments.

White Canyon and Mancos Mesa. South of Dark Canyon, to the north and west of Natural Bridges National Monument, is a broad benchland encircled by high mesas and incised by a number of small almost inaccessible slot canyons. Each of these canyons empties into White Canyon, and contributes to its intermittent flow from the Abajo Mountains to one-time Glen Canyon in the west. Cheesebox Canyon, named for a small but prominent butte, is the only WSA in this area. The landscape is a mix of thick pinyon and juniper woodlands with sparse desert shrubland dominated by blackbrush and sagebrush. The upper reaches of the WSA provide habitat for threatened desert bighorn sheep. Extensive surrounding areas in the White River drainage are RSUs similar in character. To the northwest of Cheesebox WSA are Gravel and Long Canyons, Fort Knocker Canyon, and Sheep Canyon. To the southeast and contiguous with Natural Bridges National Monument is Cheesebox RSU.

Uranium mining impacts are apparent on the sides of mesas throughout the area. Mesatops above Cheesebox Canyon are crisscrossed with roads to old and potential mines, chainings, and other landscape modifications. State Highway 95 follows White Canyon and carries many vacationers to Hite Marina at Lake Powell, but few stop on the way. The White Canyon region is little visited except by canyoneering enthusiasts, but portions of the Gravel and Long Canyon unit have recently been targeted for development as an OHV route. 
South of White Canyon is the one-time uranium mining district of the Red Canyon Plateau, now targeted for OHV use. Farther south, across Red Canyon and its highly eroded badlands, is Mancos Mesa, an enormous, rugged, and almost inaccessible area dissected by several large canyon systems. The Mancos Mesa WSA boundary runs down the middle of Moqui canyon, but the mesa itself, forming an associated RSU, continues south to State Highway 263 leading to Lake Powell. Mancos Mesa slopes down to the west, and the landscape is similar to White Canyon's, with plant life mostly desert shrubs, primarily blackbrush. The only scars on this landscape are the remnants of roads built to explore for uranium, and they remain visible from miles away, as does the unnatural-looking blue of Lake Powell.

Grand Gulch. Although the number of visitors is small, Grand Gulch and neighboring Fish, Owl, Mule, and Road Canyons are the most visited BLM lands in the county. The reasons are twofold. The Anasazi imprint on this landscape is everywhere. The cliff dwellings and rock art galleries found in the alcoves of almost every canyon make this area an outdoor museum. One cannot walk a hundred feet without encountering artifacts in the sand. Even without the cultural legacy, this landscape is extraordinarily scenic. Steep-walled canyons as much as six hundred feet deep, with pinnacles, arches, and other erosional landforms, wind for miles before opening to broad valleys. Lush riparian areas of cottonwoods and willows line the canyon bottoms. These canyons cut into the tableland of pinyon and juniper that is Cedar Mesa. which extends thirtv miles south from the Abajo Mountains. Cedar Mesa 
ends in cliffs above the San Juan River and the Valley of the Gods, an area of unique geological formations akin to the more famous Monument Valley just to the south.

A paved road splits the mesa into east and west sections. The road separates Grand Gulch WSA and its associated side canyons, which empty directly into the San Juan River, from the WSAs of Fish and Owl Canyon and Road Canyon, which empty into Comb Wash to the east. Associated RSUs for these three WSAs are numerous small parcels of mesatop above the canyons. Separated from the rest of Cedar Mesa by Utah State Highway 95 and bordering the Manti-LaSal National Forest, Mule Canyon is a small WSA with characteristics similar to the others in the Grand Gulch area. Now restricted to the mesatops, cattle have grazed these canyons for decades, and extensive impacts can be found, especially from old chainings. The proximity of Cedar Mesa to the Navajo and Ute Reservations make it a popular spot for Native American woodcutting for both ceremonial and heating purposes.

Other lands in the vicinity of Grand Gulch and Cedar Mesa, but not associated with a WSA, have been designated as RSUs. Harmony Flat is a small section of Cedar Mesa south of Natural Bridges National Monument, surrounded by paved roads on all sides. To the northeast of Mule Canyon lies spectaculat and continually controversial Arch Canyon. This broad canyon extends north into Manti-LaSal National Forest and was once recommended as a national monument. It is easily accessible by jeep or foot from Comb Wash to the east. Across broad Comb Wash lies the long narrow anticline of Comb Ridge, a peculiarly-shaped potential wilderness area. South of Cedar Mesa along the San Juan River is an area of highly eroded landforms with spectacular views 
of the river and Monument Valley beyond. Lastly, the sparsely-vegetated expanse of Nokai Dome extends west from Grand Gulch, and is bounded to the north by Mancos Mesa, and to the south and west by Glen Canyon National Recreation Area. The historic Mormon Hole-in-the-Rock trail traverses this terrain.

\section{Canyons of the Ancients. Squaw and Papoose Canyon and Cross Canyon} WSAs and surrounding RSUs lie in eastern San Juan County; these areas form small extensions of larger units in Colorado now part of Canyons of the Ancients National Monument. These are not the spectacular redrock canyons of the western part of the county, but a more gentle and open landscape. The pinyon and juniper woodlands and talus slopes with rock outcroppings of the upper canyon reaches give way to broad shallow canyons almost devoid of vegetation beyond the unit boundaries. They are ecological oases within a sea of private property and development. The surrounding grid of section roads finally breaks its pattern only when confronted with the canyon edges. Bean fields and oil pumps can be seen from these canyon rims. Bulldozed piles of dried wood, the tell-tale signs of old chainings, are found on most of the surrounding mesatops. The open canyon bottoms contain dense tangles of the invasive tamarisk, heavily grazed grasses and brush, as well as a few cottonwoods. Proximity to both Hovenweep and Canyon of the Ancients National Monuments suggests that numerous archeological sites could be located in these canyons, but they remain unexplored and little used except for cattle grazing and oil and gas exploration. Although this stretch of the Colorado Plateau in San Juan County encompasses a diverse landscape, it is the canyonlands that give it its unique character. 
Whether they are the more well known and recognizable lands of the national park, or the virtually unknown public domain managed by the BLM, these unpopulated lands capture the imagination.

\section{The Desert}

Simply noting the physical characteristics and human uses of the lands in San Juan County does not fully describe them. What has been thought and written about this desert landscape is an integral part of its depiction. Personal encounters with, and subjective interpretations of, the desert provide a more nuanced sense of this place. These texts invariably convey complex perceptions filled with contradictions and enigmas. As Joseph Krutch $(1952,240)$ said about the canyonlands, "Here the earth defies man to live upon it, and for the most part he has not challenged the defiance." The result is a complex love/hate relationship with these desert lands that informs opinions about preservation and right use of the land.

Patricia Nelson Limerick (1985) writes that attitudes of Americans towards desert lands have undergone tremendous change since the first accounts written by white settlers more than 150 years ago. The powerful reality of the desert has been associated with mythic and symbolic meanings. The desert as first encountered was a barrier to human travels and a very real threat to physical survival: the wilderness of the Bible. Limerick argues that once precious metals were discovered and irrigation works developed, that empty arid wasteland began to transform itself into a land of opportunity and economic exploitation. Only after the desert was tamed could it be 
appreciated aesthetically as a natural landscape that was pure, real, and uncontaminated, an antidote to American society.

Limerick posits that desert landscapes continue to be seen through this range of meanings in varying and overlapping degrees. She notes, however, that unlike the forested environments of the eastern part of the country, or the grasslands of the Midwest, the desert resists this last phase of aesthetic appreciation of nature. Its inhospitable nature towards human life, most obviously its lack of water, makes complete human mastery over the environment a mirage. And the reclamation projects necessary for efficient use of this water fundamentally change the appearance of the desert. A manmade landscape of lakes and farms and towns stands in stark contrast to the natural land. The tension between civilization and the desert informs its aesthetic appreciation.

The verbal images of those who love the natural environment of the desert provide insight into the depth and breadth of this aesthetic appreciation. Art history professor John Van Dyke is widely considered to be the first to praise desert aesthetics (Wild 1999). In his book The Desert, published in 1901, he described the desert much like a painting, in terms of color, light, and form. Van Dyke also responded to economic boosters of his era, saying "The deserts should never be reclaimed. They are the breathing-spaces of the west and should be preserved forever" (59). Two years later, Mary Austin's The Land of Little Rain described many of the desert lands Van Dyke lauded. She characterized the desert as a land with "little in it to love; yet a land that once visited must be come back to inevitably. If it were not so there would be 
little told of it" (5). In the 1930's, Everett Ruess became well known for disappearing without a trace into the Utah canyon country at age 20 . Before he vanished, Ruess wrote many letters describing the wonder and beauty of the canyonlands. The passionate and rapturous descriptions seem at first simply the product of youth, but they still strike a chord with visitors to this land (Rusho 1983).

Joseph Wood Krutch and Edward Abbey were two writers who popularized the desert as a place of austere and wild beauty (Wild 1999). For Krutch, recognizing the beauty of the desert reveals both a sense of a union with the whole of nature and a moral order. There are human virtues associated with desert, such as freedom and struggle and endurance, which are of a similarly austere nature. Although Krutch wrote glowingly of the delicate balance of life in the Sonoran Desert, he visited the Utah canyon country and was taken aback by this much wilder land.

"Wherever the earth is clothed with vegetation not too sparse to modify its essential outlines, it makes man feel to some extent at home because things which, like him, change and grow and die have asserted their importance. But wherever, as in this region of wind-eroded stone, living things are no longer common enough or conspicuous enough to seem more trivial than accidents, he feels something like terror. Despite the stunted junipers and harsh little shrubs upon which cattle can support themselves if they have space enough over which to wander, this is a country where the inanimate dominates and in which not only man but the very plants themselves seem intruders. $(1952,251)$

According to Graber (1976) Abbey approaches the desert in the tradition of the Romantic sublime, and he is one of the first to see that quality in a place other than the mountains. Although Abbey said it was impossible to get the desert into a book, this did not keep him from tying. Desert Solitaire (1968), a distillation of his time spent as a ranger in what was then Arches National Monument, remains the 
preeminent celebration of the Utah canyonlands wilderness. Abbey's desert is a

landscape that is stripped of human meaning,

"The desert lies there like the bare skeleton of Being, spare, sparse, austere, utterly worthless, inviting not love but contemplation. In its simplicity and order it suggests the classical, except the desert is a realm beyond the human ... The desert waits, untouched even by the human mind." (272)

This desert wilderness is sacred space, "the Wholly Other from man, and it is to be valued for that reason" (Graber 1976,11). Wilderness offers the opportunity for transcendence of the self and the ordinary world. To do so, one must recognize the vastness and power of nature and man's resulting insignificance, and in so doing one attains a sense of unity with this natural world.

Terry Tempest Williams echoes this idea in recent writings about the Utah wilderness. "If the desert is holy, it is because it is a forgotten place that allows us to remember the sacred. Perhaps that is why every pilgrimage to the desert is a pilgrimage to the self. There is no place to hide and so we are found" $(2001,77)$. Many contemporary writers such as Williams, Gary Paul Nabham, and Barry Lopez have turned their appreciation for the beauty of the desert into an advocacy for wilderness. For Ward Roylance, the lands of southern Utah have worth "... not as a golden opportunity for indiscriminate industrial exploitation and expanding urbanization ... but as a precious wilderness, valuable to the world for its peace and loneliness as well as its minerals, for its inspiring beauty and strange enchantment as well as its boundless opportunities for physical recreation ..." (1971)

A recent European visitor to the American desert finds a different set of deeper meanings there. Jean Baudrillard (1985) sees the desert as the perfect 
expression and critique of American (non)culture. He sees in the desert the ideas culture has imposed on it through films, artwork, and photographs such as nothingness, waste, and inhumanity. Of Monument Valley, Baudrillard says,

"The very idea of the millions and hundreds of millions of years that were needed peacefully to ravage the surface of the earth here is a perverse one, since it brings with it an awareness of signs originating, long before man appeared, in a sort of pact of wear and erosion struck between the elements. Among this gigantic heap of signs purely geological in essence - man will have had no significance ... It is perhaps these reliefs, because they are no longer natural, which give the best idea of what a culture is. Monument Valley: blocks of language suddenly rising high, then subjected to pitiless erosion, ancient sedimentations that owe their depth to wear ... and that are today destined to become, like all that is cultivated - like all culture - natural parks." (3)

Preserved nature becomes a simulation of itself, and a symbol of cultural dominance of nature.

Human standards of beauty stem from an objectification of the natural world and a reification of abstract ideas of the picturesque, the sublime, and the beautiful. Neil Evernden (1981) contends that since it is difficult to objectify vast landscapes such as deserts, they become less beautiful. These landscapes need to be manipulated to be made picturesque. Images must be composed for a sense of profundity and drama leading one to think that the desert is actually composed of such images. (3) When one becomes accustomed to the simulacra, the reality of the landscape can often be disappointing (Lawrence 2001). To Peter Reyner Banham (1982), Englishborn and best known as an architectural critic, the desert also is not picturesque or sublime in any historical sense, and does not equate to traditional standards of beauty such as a European pastoral landscape. People are more likely to see the desert 
through the filter of film, especially classic westerns, and Monument Valley is the canonical image of the American Desert. Popular photographic representations of the desert are also of a similat composition, with the endless sagebrush plain extending towards distant mountains or striking geological formations. But to Banham himself, the desert is essentially disembodied and unfocussed light and color. He synthesizes the ideas expressed by desert lovers from Van Dyke to Abbey when he questions whether to call the desert beautiful or mystical is to attempt to "...categorize, and thus tame, responses that were not tame, and far outside the categories of common physical experience... beyond our reasonable expectations of how the world should appear?" (225).

As Limerick has noted, the desert retains a number of meanings beyond that of a beautiful place that is the antithesis of civilization. For many Americans, different mental images, perspectives, and myths other than aesthetic appreciation would define the arid lands west of the $100^{\text {th }}$ meridian. 


\section{CUSTOM AND CULTURE}

\section{Frontier Legacy, Western Paradox}

Frederick Jackson Turner postulated in 1893 that "the existence of an area of free land, its continuous recession, and the advance of American settlement westward explain American development" (quoted in Smith 1950, 250). This hypothesis has defined the idea of the frontier as a process, not a place, a "meeting of savagery and civilization." For Turner, the frontier ends when there are no vast tracts of land left for settlement. Henry Nash Smith (1950) describes this idea of a democratic American society born out of the wilderness as a mythic rebirth and regeneration, where a utopian agrarian society is formed. A symbolic fertile garden is created: a place of fruitful labor and growth with the frontier farmer as its centerpiece. But the Turnerian process also holds that civilization develops through a series of progressively higher social stages. Turner's frontier farmer is but a primitive stage in the process of growth towards a higher civilization.

If this contradiction were not difficult enough, settlement of the so-called

frontier ran headlong into the geography of the arid region west of the $100^{\text {th }}$ meridian. John'Wesley Powell, in his Report on the Lands of the Arid Region of the United States in 1878 , was the first to suggest that there were limits to settlement (Stegner 1954). The ideas about the frontier farmer and the fertile garden, and associated laws of public land disposition, would need revision to account for the geography of the West. Since 
the Turner frontier hypothesis took water for granted, the arid West was effectively ignored in this historical process. Turner announced that the frontier had closed by 1890, just when much of the West was starting to be settled (Limerick 1987).

Recently, "new western historians" put forth a wholesale revision of the frontier settlement story (Limerick 1987; Worster 1992a, b). The reality of the settlement of the West is fat removed from the myth; it can be seen as a ruthless conquest of native peoples and of nature itself under the guise of economic progress. Federal land policy, at least until the 1890's, assumed the land was to be appropriated and put to beneficial, meaning economic, use. For many who write about this western experience (DeVoto 1955; Stegner 1991; Worster 1993a), it is a time when unrealistic expectation, carelessness, and greed dominated. Limerick writes that "Western history may well be the most dramatic and sustained case of high expectations and naivete meeting a frustrating and intractable reality" $(1987,29)$. Transient natural resource extraction, not settlement and farming, became the new way of life in this arid land, and the boom-and-bust economy was dependent on the vast public lands. $A$ chief victim in this process has been the land itself, particularly in the fragile arid environment. Graf (1990) characterizes this phase of western history as a series of rebellions over usufruct rights, first for water, then forest resources, and finally grazing privileges. Each follows the same pattern of explosive development followed by testrictive regulation, and then rebellion against an ever-growing federal management role. The land use practices and laws that developed in this era, what Charles Wilkinson (1992) has termed the "Lords of Yesterday", temain in place today. 
The old frontier settlement myths did not just go away; they have been adapted to this new environment of mountains and desert. The result is what Donald Worster has called the western paradox (1992c). The West was the last frontier, a place of freedom, where an individual could live as part of nature, free of the expectations and responsibilities of society. The wide-open landscape of the West may have even encouraged these thoughts. But at the same time, the West was a land of economic opportunity, of societal progtess and growth. What was different about the West, as Worster notes, is that the technological changes of the $19^{\text {th }}$ century were necessary to tame and exploit its harsh environment. The foremost expression of this new technology was the monumental reclamation projects of the first half of the twentieth century. These projects extended the possibility of settlement far beyond what John Wesley Powell could have imagined. Worster argues that reliance on technology also led, by necessity, to both federal bureaucratic control and concentration of power in the hands of industrial elites. The reality of the power and influence of industrial society and the federal government in the West is not easily reconciled with a belief in the freedom and unique character of the frontier American.

Richard White (1991) acknowledges that the mythic West and the historic West are not necessarily distinct and separate entities. Each influences the other. The mythic West is a shifting construct, sometimes located in a place and sometimes in the mind, one that embraces the construction of myths and associated values such as individualism and success (DeLyser 1999). Thomas and Geraldine Vale (1989) suggest that some common, and often contradictory, landscape meanings in the West reflect a 
thinking that has changed little since the $19^{\text {th }}$ century. The West is still the frontier of freedom and a past way of life, a land of opportunity, a pastoral middle landscape of small towns within the larger fabric of wild nature. But the West is also an arid and empty desert wasteland, a land of resources to be plundered, and a place for economic growth and societal progression.

Utah is as much a part of the historic and mythic West as any other western state. However, the Mormons have added their own unique twist to the story.

\section{Latter-Day Saints}

The Mormons have been perceived as a distinctive culture within American society ever since the Church of Jesus Christ of Latter-Day Saints was started in the 1820 's. However, it was their settlement of Utah, beginning in 1847 , that created an entire cultural region. Donald Meinig's seminal study (1964) defined this Mormon culture region using the ideas of a core, domain, and sphere of influence. These gradations in the content and situation of the culture were based not only on where one finds Mormons in the religious majority, but also on the context of these locations and the processes that created them. The core is found along the Wasatch Front, and the Salt Lake City metropolis clearly remains the historical, cultural, and economic center of the region. The majority of region's population that is not Mormon, socalled Gentiles, have also always lived in this core.

The domain as defined by Meinig is the most thoroughly Mormon area and covers most of the remainder of Utah, extending north into eastern Idaho and west 
into southern Nevada. Much of the scholarship on the Mormon culture region describes this area's exceptionalism within the American landscape (Francaviglia 1978; Kay 1995; Norton 1998). These studies focus on village settlement patterns in agricultural valleys and how these landscapes resulted from a religious group identity and social control. Richard Jackson (1981) notes how the percentage of population living in this rural domain has steadily decreased over the last one hundred years, after it became clear that these arid rural lands can only sustain a limited number of people.

The Mormon sphere of influence encompasses areas with isolated Mormon settlements, and it extends into Western Idaho and Eastern Oregon as well as into eastern Arizona and western New Mexico. This boundary between domain and sphere of influence is continually changing. Meinig specifically mentions southeast Utah as an area that straddles this boundary because of considerable outside influence from mining activity. Explosive tourism growth and growing Native-American activism are other more recent forces that have pushed against this boundary.

If there is a distinctive Mormon culture region, one might expect to find a uniquely Mormon view of the environment and the best use of the land. John Wright (1993) explores this topic in a comparison of Utah with neighboring Colorado. He directly attributes Utah's opposition to conservation to the Mormon belief system. According to Brigham Young, Mormons are to prepare for Jesus' return by establishing a society, Zion, which under church guidance would create an Edenic garden through "pragmatic mastery of the forces of nature" (quoted in Flores 2001, 128). Physical improvement of the land is associated with spiritual improvement of 
humans, and this relationship leads to the idea of limitless economic growth that continues to guide Utah today.

How Mormon views of the environment vary from those of other Christians is not clear. The Christian belief system in general has often been criticized as the root of western attitudes towards the environment. Much is made of the lines from Genesis I: 27-28 to "be fruitful and multiply, replenish the earth and subdue it." The religion establishes a profound divide between humans and nature that results in an arrogance and hostility towards the natural world (White 1967; Turner 1983). Other scholars have argued that Christian thought has many diverse interpretations of nature and cannot be distilled to a simple anti-environmental stance (Doughty 1981; Worster 1993a; Callicott 1998). Contrary to conventional interpretations (Nash 1982), both Callicott (1991b) and Worster (1993b) have argued that the wilderness preservation idea itself has a Protestant, and specifically Puritan, heritage. A preoccupation with man's fall from grace leads to the belief that the unnatural, unholy works of civilization have fouled the perfect beauty of God's creation manifest in the pristine wilderness. Many of the early defenders of wild places, from Thoreau to Muir, emerged from this background.

Jeanne Kay and Craig Brown (1985) and Dan Flores (2001) note that although Mormons worked under a religious mandate to "improve" the wilderness, there is ample evidence that they had a frontier conservation ethic within their agrarian ideal. Land ownership was divine and humans were simply stewards who were not to waste resources. This environmental ethic is also attributed to the Mormon belief in the 
creation of Zion in Utah, and to a much greater inclination to stay put than the average get-rich-quick westerner. In their early years of settlement in Utah, Mormons lived largely outside the spirit of capitalism that dominated most of the country. Kay and Brown recognize that the mere existence of a conservation ethic and knowledge of limited resources does not preclude harmful land-use practices. This proved to be especially true in an arid land where the Mormons had little notion of its carrying capacity. Flores also notes that this stewardship was one of indirect ethics, where right use is simply an attempt to please God, and no rights are afforded to nature.

The end result was that this conservation ethic had little lasting impact on the landscape. The coming of the railroad to Utah in 1869 brought Gentiles to compete for resources, and Brigham Young, the greatest proponent of this conservation ethic, died in 1877. Soon Mormon views towards the environment Americanized. (4)

\section{On the Outskirts of Mormon Country}

"We have watched the pioneers of San Juan batter down the barriers of the wilderness, making a breach so wide that people have come from far and near to enjoy the opening." (Albert Lyman 1917, quoted in McPherson 1995, 3)

In a history commissioned as part of Utah's statehood centennial commemoration, Robert McPherson (1995) describes the three events that became the best known symbols of San Juan County's heritage: The Hole-in-the-Rock expedition of the first Mormon settlers, the stories of the early cattle industry and the lawless frontier West, and the last Ute Indian uprising, termed the Posey War of 1923. These stories are important for understanding what it means to be from this area, 
what has been called the "San Juan mystique" (170). As McPherson notes, such an assessment has privileged the era of white settlement at the expense of the Native Americans who make up the majority of the county population. Some have even said that the old battles with the Utes and Navajos continue to this day in different guises (Wilkinson 1999). However, it is this minority of the county population that actively advocates against wilderness designation, and it is their story that dominates this short history of the county.

Before the Mormons. The wilderness that greeted the Mormon pioneers was not always empty. To this day, the remnants of the culture of the enigmatic Anasazi, the first residents of San Juan County, remain one of the dominant characteristics of the landscape. Archaeologists identify three distinct culture groups for the Anasazi: Archaic, Basketmaker, and Pueblo. The Basketmaker people were the first to build permanent settlements, generally pithouses, starting around $1000 \mathrm{BC}$. However, it is the Pueblo culture, which began in $750 \mathrm{AD}$, that is the most visible. Cliff dwellings and towers were built during the Pueblo III period from AD 1150-1300. There are no examples of later Pueblo culture in the area, since a mass migration to the Rio Grande region of what is now New Mexico occurred in the $14^{\text {th }}$ century. Many reasons have been postulated for this abandonment of the Canyonlands and the areas around Mesa Verde, including overuse of natural resources, climate change, and warfare. Richard Weatherill, one of the brothers who "discovered" Chaco Canyon and Mesa Verde, was the first white man to explore the Grand Gulch area in 1893. Archaeological work in the area has been steady ever since, as the county contains an estimated 100,000 
archaeological sites. Most are still undocumented, and 90 percent of the known sites have been disturbed (McPherson 1995).

Utes and Paiutes arrived from the Great Basin about the time period the Anasazi departed. The limited archaeological record of the new arrivals leaves no clue as to whether these groups had any contact. Navajos arrived from the north in about the same time period. The earliest known structure attributed to them is from 1620 , coinciding with the earliest Spanish documentation of the region. The first Europeans known to have visited the region were Spanish soldiers engaging in sporadic combat with the Navajo and Ute (McPherson 1995).

For early European visitors, San Juan County was not a destination so much as a stopping point on the way to somewhere else. Two priests, Francisco Atanasio Dominguez and Francisco Silvestre Escalante, crossed the northwest corner of the county in 1775 in search of passage from Santa Fe to California, now known as the Spanish Trail. Captain John Macomb of the Army Corps of Engineers came next while mapping the Spanish Trail in 1859. After crossing the Great Sage Plain, which he described as "exceedingly monotonous," Macomb was overwhelmed by the Canyonlands area and become the first to write of its beauty.

"These castellated buttes are from one thousand to fifteen hundred feet in height and no language is adequate to convey a just idea of the strange and impressive scenery formed by their grand and varied outlines. Toward the west the view reached some thirty miles ... while in the intervening space the surface was diversified by columns, spires, castles, and battlemented towers of colossal but beautiful proportions, closely resembling elaborate structures of art, but in effect far surpassing the most imposing monuments of human skill ... Their appearance is so strange and beautiful as to call out exclamations of delight from all our party." (quoted in McPherson 1995, 88) 
After Macomb, John Wesley Powell's Colorado River expedition floated through in 1869 and Ferdinand Hayden conducted surveys in the area in 1875 and 1876.

The Pioneers. More than thirty years after the Mormons first settled in Utah, the southeast remained essentially terra incognita. The earliest Mormon settlement in the region in 1855 , at what is now Moab, lasted only four months. Jackson (1981) recounts how most Mormons viewed the southern landscape as harsh and undesitable compared with the valleys they originally settled along the Wasatch front. However, the Mormon Church fashioned the story of how the Mormons could make the desert bloom into a myth independent of the actual nature of the land. In 1878, the church directed Mormons living in southwest Utah to settle the southeast, with the goals of expanding Mormon control, improving Indian relations, and reining in white outlaws.

An exploratory party traveled through Northern Arizona to San Juan County in 1879 and returned on the Spanish Trail. Two families stayed at Montezuma Creek just north of the San Juan River. In November of that same year, 230 people set out from Escalante on a more direct route across southern Utah, on what is now known as the Hole-in-the-Rock expedition. Winter snows had already blocked their retreat when they came to the formidable obstacle of Glen Canyon. The party built a road through a break in the cliffs and down 1200 feet into the canyon during the winter of 1879/1880. They eventually arrived at Montezuma Creek in April of 1880, and founded the first permanent white settlement in what is now San Juan County (Powell 1983). 
This harsh land proved much more difficult to inhabit than other parts of southern Utah. The traditional Mormon settlement, centered on irrigated agriculture, proved unsuccessful as floods regularly wreaked havoc. As a consequence, the Mormon settlers eventually turned first to cattle ranching and then to dry farming of wheat and beans on the Great Sagebrush Plain, and settlements moved away from the San Juan River. The towns of Monticello and Blanding, founded at the foot of the Abajo Mountains in 1888 and 1905 respectively, relied on runoff from mountain rainfall as source of water (McPherson 1995).

Large cattle companies, such as New Mexico Cattle and Land Company and the Pittsburgh Cattle Company, had already moved into what is now San Juan County during the 1880 's. An estimated 100,000 cattle, and as many sheep, were (over)grazing the county by 1885 , predominantly in the Abajo and LaSal Mountains. Aided by a national downturn in the cattle industry in the late 1880's, the Mormon settlers were eventually able to wrest control of the land from the cattle barons. By 1896 the outside cattle companies were gone, leaving only stories of the Wild West and the beginnings of a ranching tradition unique in Utah. Elsewhere in the state, rangeland was. held by the Mormon Church in support of the community. In San Juan County, tanches became traditional western capitalist enterprises (Peterson 1983).

The first federal controls of grazing were put in place in the area with the creation of the LaSal and Monticello Forest Reserves in 1906 and 1907 respectively. In 1934, at the time of the Taylor Grazing Act, there were 193,000 sheep and 25,000 cattle in the county. Since that time, the number of cattle has held fairly constant, 
while the number of sheep steadily decreased, and they are no longer grazed in the county (Peterson 1983). Although not as important as in other areas of the West, timber was another resource to be found in the forest reserves. The harvest of Douglas fir and ponderosa pine began in the 1910's and peaked in the 1960's (McPherson 1995).

The Resource Extraction Boom. In San Juan County, as elsewhere in the West, the public lands administered by the BLM hid great potential wealth. Uranium was first discovered in exposed outcrops in the Chinle sandstone formation that is found throughout southeast Utah, along with vanadium and copper. The fitst uranium mining boom in the mid 1950's supplied raw material for nuclear weapons programs. After a downturn in the early 1960 s, a second boom supplied commercial nuclear power plants from the late 1960 s and until the 1980's. Cheaper foreign sources of uranium, and concern about nuclear power plant safety, effectively put an end to uranium mining in the county. Most uranium was mined in the Lisbon Valley, around White Canyon, and near Monument Valley. The Happy Jack mine in the White Canyon area remains one of the few still in operation today, and White Mesa Mill near Blanding is the only mill remaining in the country, operating off and on since 1990 (Utah Department of Natural Resources 1992). Copper has also been mined in White Canyon and Lisbon Valley since 1918, but ore deposits were never of a sufficiently high grade to make large operations worthwhile. As with uranium, interest in copper mining still remains high, but the price stays too low (McPherson 1995). 
Oil was first discovered in 1907 near the town of Mexican Hat. However, not until 1956 were commercial quantities of oil and gas found in the Blanding Basin, along the eastern edge of the county near Aneth. This field, together with another discovered in 1960 in Lisbon Valley, continues to be most productive, making San Juan County the largest oil-producing county in Utah. New exploratory methods have recently located oil in several locations near Canyonlands National Park. Coal beds are found throughout southern Utah, but those in San Juan County are thin discontinuous outcrops, and generally of poor quality (Utah Department of Natural Resources 1992). Tourism. The public lands hold a large supply of another resource that can be exploited or appreciated, and that is their scenic wonders. Three small national monuments are in San Juan County: Natural Bridges, designated in 1908 and expanded in 1961; Rainbow Bridge, designated in 1910; and the Anasazi ruins of Hovenweep, designated in 1923. State Parks created between 1959 and 1962 include often-photographed Deadhorse Point on the Colorado River, the geological classroom of the Goosenecks of the San Juan River, and the large petroglyph panel of Newspaper Rock in Indian Creek Canyon. After considerable debate and compromise about its size, and whether or not to retain its predominantly wilderness character, Congress created Canyonlands National Park in 1964. County commissioners supported the park in general but would later complain about the lack of development of tourist infrastructure. Nonetheless, visitation increased from 26,300 in 1968 to 434,800 in 1993 (McPherson 1995). 
By far the biggest tourist attraction on the entire Colorado Plateau is Glen Canyon National Recreation Area. In existence since the completion of Glen Canyon Dam on the Colorado River in 1963, it consists of lands surrounding the 185 -mile long Lake Powell reservoir in four Utah counties and Arizona state. There are five marinas on Lake Powell, two in San Juan County, and a high of 3.6 million tourist visitors in 1993 (McPherson 1995).

Less visited but familiar from countless movie westerns and television commercials is Monument Valley. Located mostly in neighboring Arizona, these reservation lands became a Navajo Tribal Park in 1960. Least visited of all is the canyon country of the BLM lands. In 1972, Grand Gulch and Dark Canyon were designated as primitive areas and restricted to nonmotorized recreation. These are the only areas in the county where the BLM monitors visitation. A high of 12,000 visitors was tallied in 1993 at the Kane Gulch Ranger Station near Grand Gulch, although the BLM estimates that the actual number is double (personal communication with BLM personnel 2002).

San Juan County Today. Based on census data from the year 2000 (US Census Bureau 2004), San Juan County is the 13th most populous of 29 counties in Utah, with 14,413 residents. It is the largest county in land area at 7,933 square miles, making it one of the five least densely populated counties at 1.8 persons per square mile. The workforce numbers 4,985 and the unemployment rate is $15 \%$, but an astoundingly high $31.4 \%$ are below poverty level, predominantly on the Navajo and Ute reservations. Only $7.3 \%$ of jobs are in traditional resource extraction industries such as 
agriculture, mining, and forestry. Federal or local government supply $34.1 \%$ of the jobs, and $72.4 \%$ of the entire workforce is employed as an office worker, a professional, or a service industry employee.

Travel-related services employment is estimated to be around $20 \%$. In contrast, neighboring Grand County with its well-known mountain biking capital, Moab, employs $45 \%$ of its workforce in tourism. Although once dependent on uranium mining, Grand County has successfully shifted from a resource extraction economy to become a gateway community for tourism, recreation, and retirees (Utah Division of Travel Development 2003).

Undoubtedly, Anglo-American settlement of the region is dominated by descendents of Mormon pioneers. However, as noted earlier, San Juan County lies on the perimeter of the Mormon cultural region. This physical and cultural isolation has allowed outside influences to play an important role in the region, from cattlemen in the late 1800 's, to miners in the 1950 's and 1960 's, to the tourists in the 1990 's. The Navajo and Ute reservations comprise a quarter of the county land and Native Americans are more than half of the population, making their interests and concerns integral to those of the county as a whole. Proposals to split the county between reservation and nonreservation land have so far been unsuccessful (San Juan Record 1996). Neighboring Colorado remains outside the Mormon sphere of influence. Its seemingly arbitrary straight-line border is a former reservation boundary, and the meeting place of western-moving settlement in Colorado with eastern expansion in Utah. 
Frederick Jackson Turner defined the frontier in 1893 as areas with less than two persons per square mile. Employing this definition, Frank Popper found that there are still 144 frontier counties in 15 Western and Midwestern states based on 1980 census figures (Starrs 1998). In the year 2000, this number stands at 149 frontier counties, constituting 25 percent of the land in the United States. The increasing urbanization of the West masks the fact that much of its land area remains sparsely populated, a so-called frontier of mostly public lands. San Juan County is one of those places. In more ways than might be expected, both the real and the mythic frontier live on in San Juan County. As the website for San Juan County Community Development (2003) claims,

"This is the real West; unromanticized and unsanitized; unpolished, not filtered through the expectations of city dwellers. . . we are proud of our western heritage: the hardscrabble tradition of pioneers, depression era wheat farmers, and cattle ranchers. Our heritage is a veil through which we view the twentyfirst century." 


\section{CONSERVATION}

\section{Acts of National Contrition}

"... wilderness areas are components of the American map representing all that is best about a nation that is so incredibly wealthy that it can afford to set them aside; a nation so wise that it can make a divisive but collective decision in favor of preservation." (Graf 1990, xii)

George Perkins Marsh's Man and Nature, published in 1864, described how human actions have modified the natural environment to harmful effect. Marsh warned that the United States was poised to join the long line of civilizations that had caused their own destruction by uncontrolled exploitation of natural resources. By the late $19^{\text {th }}$ century, Marsh seemed a prophet. The era of settlement and unchecked economic expansion had taken its toll on the public lands. Entire forests had been logged out of existence and more were at risk. Cattle and sheep had overgrazed the arid lands of the West in just a few decades. Without dramatic changes in public land policy, destruction of the environment was likely not just to continue but to accelerate (Jackson 1995).

The conservation movement in the United States began with the establishment of national parks to protect scenic natural wonders. In 1872, Yellowstone National Park became the first land to be permanently reserved under federal ownership. However, not until 1891 did large withdrawals of federal land commence with the establishment of the first forest reserves for the purpose of preservation and watershed protection. The 1897 Organic Act, which established the Forest Service 
added a third purpose: timber supply. As practiced by the Forest Service, conservation was for utilitarian purposes, not for preservation of the natural environment (Loomis 1993). Gifford Pinchot, the head of the Forest Service, envisioned that the forest reserves would be managed by professionals for ". . . the greatest good for the greatest number in the long run" (Wilkinson 1992, 128).

This change of purpose of the forest reserves left the national parks as the only federal lands managed exclusively for preservation and protection of the natural environment, not commodity use. The National Park Service (NPS) was established in 1916 with a twofold purpose, "To conserve the scenery and the natural and historic objects and wildlife therein and to provide for the enjoyment of same in such a manner and by such means as will leave them unimpaired for the enjoyment of future generations" (Loomis 1993, 54). Under the guidance of Stephen Mather, its first director, the national park system would concentrate on the enjoyment half of the mission. The new idea of protected wilderness would be different, since it would focus on preserving wild nature unimpaired, rather than on its enjoyment (Nash 1982).

A New Land Use Category. In 1920, the first roadless and undeveloped area was designated on national forest land at Trapper Lake in Colorado, based on the recommendation of the young landscape architect Arthur Carhart, who had surveyed the area for development. However, it was Aldo Leopold who articulated the idea of conserving large areas of national forest land in their natural state as a land use category called wilderness. In 1924, more than 500,000 acres of the Gila National Forest in southwest New Mexico was designated for wilderness protection. In the 
process of developing the wilderness preservation idea, Leopold also began to formulate arguments that ultimately resulted in his land ethic, which continues to influence environmental thinking today. For Leopold, designation of wilderness was "an act of national contrition" (quoted in Nash 1982, 199) and wilderness became the baseline against which the deleterious impacts of humans on other lands.could be measured. Sustainable land use based on the scientific principles of ecology would replace unrestrained growth (Nash 1982).

In the 1930's, Robert Marshall became the preeminent crusader for wilderness conservation. Marshall espoused the beneficial effects of wilderness for the mental health of civilized man, as well as its aesthetic importance. He recognized that wilderness was quickly disappearing under the juggernaut of economic development. He co-founded the Wilderness Society in 1935, with the hope of resisting destruction of the wilderness through an "organization of spirited people who will fight for the freedom of the wilderness" (quoted in Nash, 206). In 1936, Marshall published a map of the largest remaining roadless areas in the country. The largest of these, at 8.9 million acres, was the canyon country of southern Utah (Wheeler 1988a).

Defending the Wildlands of Utah. In the first proposal made for wilderness protection in Utah, Secretary of the Interior Harold Ickes proposed the creation of a 4.4 million-acre national monument in southern Utah in 1936. This would-be national monument stretched from Moab west to the town of Escalante and south to the Arizona state border. At the time, southern Utah was little known and seldom visited. Only the geological wonders of Zion and Bryce Canyon National Parks and Arches 
National Monument, a total of 250,000 acres, were protected. Ickes' proposal was eventually pared down to only 1.5 million acres, but it was never approved because of the vehement opposition from western congressmen and the great western triumvirate of grazing, logging, and mining interests (Watkins 2000).

Publicizing the continued resource abuse of federal lands by this western tric of resource users was to become a powerful recurring theme amongst conservationists, and one of the major arguments for protection of these lands in thi natural state. Bernard DeVoto (1934) described the West as a "plundered province," colony beholden to powerful Eastern economic interests. Its economy relied on exports of raw materials, and the inevitable result would be exhaustion of those very resources. Westerners themselves were complicit in this system of resc exploitation, provided they receive their share (DeVoto 1955). Recent scholarship suggests that DeVoto's idea of the West as a plundered province dominated by resource extraction is still as accurate fifty years later, even if the details have changed. The controlling interests now include western urban centers and even international corporations, but the colonists have remained in control (Robbins 1986). The alternative to this economic system is one that does not liquidate its resources, but conserves them.

The signature environmental conflict that pushed the wilderness preservation argument to the forefront nationally was the proposed Echo Park Dam in Dinosaur National Monument in northern Utah (Harvey 1994). This Bureau of Reclamation project would have flooded the wild and spectacular canyons of both the Green and 
Yampa Rivers for their entire lengths within the national monument. From 1950-1956, a group of noted conservationists, including Howard Zahniser of the Wilderness Society and David Brower of the Sierra Club, as well as writers such as DeVoto and Stegner, fought against the building of the dam. In the end, the dam was not built in Dinosaur National Monument. Ironically, the alternative site chosen for the dam was equally beautiful but little-known Glen Canyon on BLM-administered lands in southeast Utah, now filled by Lake Powell.

Nonetheless, the success of this effort was a galvanizing force for a growing wilderness preservation community and created a common national mission. As Samuel Hays (2000) has suggested, increased income levels and standards of living in the post-World War II era provided the basis for a shift in attitudes towards the environment. This new constituency for wilderness preservation was educated, predominantly from urban areas, and for the most part middle class. Better standards of living meant more leisure time and a desire for the amenities of life, not just its material rewards. The increased mobility provided by the automobile allowed these Americans to take vacations to the national parks and forests, and in the process, they developed a greater appreciation for natural beauty and a desire to protect it.

The Wilderness Act. A logical outgrowth of the success at Dinosaur National Park was the development of legislation that would provide legal endorsement of the wilderness concept. It had become clear that the national park system would not permanently protect latge tracts of lands from development. A stronger law was needed. Many policy changes had been recommended through the 1920's and 1930's 
that called for protecting wilderness against development, but statutory wilderness had never been successfully proposed. From 1957-1964, Congress held nine separate hearings to discuss a proposed wilderness act written by Zahniser and introduced into congress by Senator Hubert Humphrey and Representative John Saylor. Over the course of those years, the legislation was rewritten 66 times. But the volume and passion of the public support for wilderness preservation was high. In what came to be called the Wilderness Letter, Wallace Stegner wrote the famous lines, "something will go out of us as a people if we ever let the remaining wilderness be destroyed ... We need wilderness preserved-as much of it as is still left, and as many kinds- because it was the challenge against which our character as a people was formed. The reminder and the reassurance that it is still there is good for our spiritual health even if we never once in ten years set foot in it. $(1969,146,147)$

Although adamantly opposed by many industrial and development interests, the Wilderness Act finally became law in 1964 . Nine million acres of national forest land in 54 areas and 13 states were designated as wilderness. Although a far cry from initial proposals for more than 60 million acres of wilderness, the Wilderness $A c t$ was a major victory for the conservation movement (Nash 1982).

Today the national wilderness preservation system has grown to a total of 105 million acres in 662 areas and 44 states. Less than five percent is outside the 13 western states, and better than half of the total acreage is in Alaska (Wilderness Information Network 2004). The designation of wilderness areas by year is shown in Figure 7, and a breakdown by federal land management agency is shown in Table I. 
Figure 7. Wilderness Designated by Year

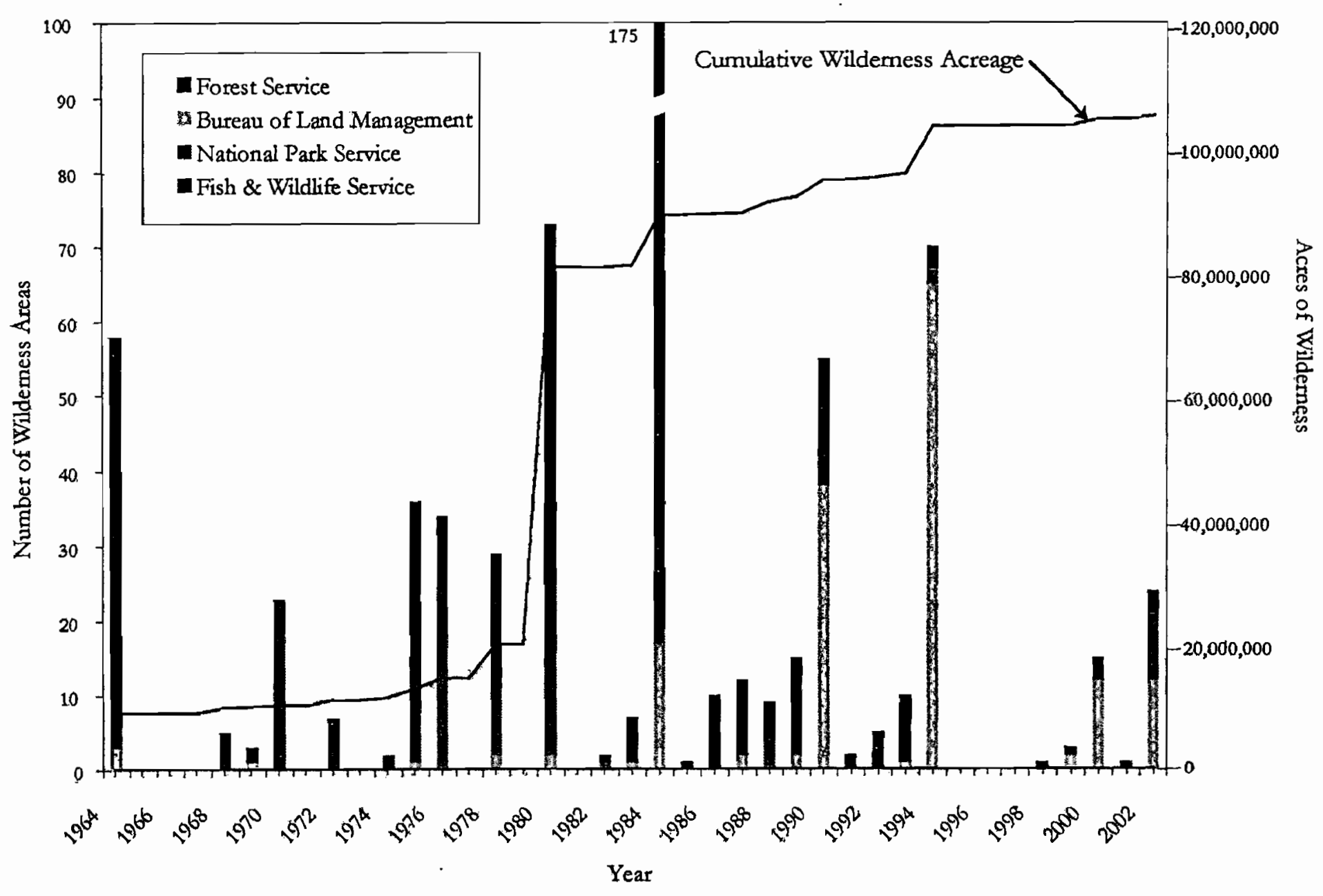


TABLE I. WILDERNESS AREAS BY LAND MANAGEMENT AGENCY

\begin{tabular}{llllll}
\hline & $\begin{array}{l}\text { National } \\
\text { Park } \\
\text { Service }\end{array}$ & $\begin{array}{l}\text { Forest } \\
\text { Service }\end{array}$ & $\begin{array}{l}\text { Fish and } \\
\text { Wildlife } \\
\text { Service }\end{array}$ & $\begin{array}{l}\text { Bureau of } \\
\text { Land } \\
\text { Management }\end{array}$ & Total \\
\hline $\begin{array}{l}\text { Number of Areas- } \\
11 \text { Western States }\end{array}$ & 33 & 346 & 15 & 161 & 446 \\
$\begin{array}{l}\text { Wilderness } \\
\text { (million acres)- }\end{array}$ & 8.7 & 26.1 & 1.5 & 6.5 & 41.3 \\
$\begin{array}{l}\text { 11 Western States } \\
\begin{array}{l}\text { Number of Areas- } \\
\text { Lower 48 States }\end{array}\end{array}$ & 44 & 387 & 50 & 161 & 642 \\
$\begin{array}{l}\text { Wilderness } \\
\text { (million acres)- }\end{array}$ & 10.4 & 29.1 & 2.01 & 6.5 & 48.0 \\
$\begin{array}{l}\text { Lower } 48 \text { States } \\
\text { Number of Areas- } \\
\text { Total }\end{array}$ & 54 & 406 & 71 & 161 & 692 \\
$\begin{array}{l}\text { Wilderness } \\
\text { (million acres)- }\end{array}$ & 43.6 & 34.9 & 20.7 & 6.5 & 105.7 \\
\hline \begin{tabular}{l} 
Total \\
\hline
\end{tabular}
\end{tabular}

Source: Wilderness Information Network (2004). 


\section{The Idea of Wilderness}

"Wilderness, it sometimes seems, is like right action or pornography: we may have difficulty in defining it, but we think we know it when we see it." (Maskit 2002, 265)

The definition of and value associated with wilderness have prompted considerable scholarship and philosophical debate. While these abstract discussions often bear little resemblance to debate about the policy of wilderness designation, they postulate varied relationships of humans to nature, and provide the most broad context for this study. Clarence Glacken (1967) in Traces on the Rhodian Shore explores the western roots of that relationship from the ancient Greeks through the seventeenth century. In his classic work Wilderness and the American Mind, Roderick Nash (1982) moves the story across the Atlantic and picks up where Glacken left off. Nash describes how the uniquely American idea of wilderness developed over time. To the new arrival to America, wilderness was a terrifying place, the biblical wilderness, the antithesis of civilization. During the settlement of the frontier, the wilderness became a challenge to overcome and to civilize. As the wilderness was conquered, it could then become a representation of beauty and the sublime. Nash argues that this latter concept of wilderness was an outgrowth of both European Romanticism and the transcendentalism of Thoreau, a belief that the natural world is a manifestation of God. These ideas stress the primacy of the subjective in the experience of the wild. John Muir further developed and popularized the idea of the spiritual value of wilderness. In $A$ Sand County Almanac, Aldo Leopold (1949) merged the spiritual with the scientific into an ecologically-based land ethic that was the 
precursor of both environmental ethics and a more scientifically-oriented evaluation of wildlands. As Nash notes, Leopold's arguments broaden the scope of the discussion of the natural world beyond the anthropocentric conservation and preservation arguments to recognize the value of nature outside of human use.

Evidence of this ever-widening range of discussion is found in a recently published comprehensive and voluminous work, The Great New Wilderness Debate, edited by J. Baird Callicott and Michael Nelson (1998). This volume collects essays for and against the wilderness concept over a vast rage of perspectives from early American conservationists to third and fourth world critiques to postmodern deconstruction.

Instead of the perspective of a progression, Michael Soule (1995) describes a typology of human constructions of nature that coexist to varying degrees. Many of these constructions serve as arguments for the value and preservation of wilderness, and similar compilations have been made by numerous scholars (Nash 1982; Rolston 1986; Nelson 1998). Some of these views of nature are based on ancient beliefs, in which the natural world is understood as either a mindless force of catastrophe and unpredictability, or a provider of food, medicine, and other resources that support human life, such as clean air and water. Another ancient perspective, an animist pagan sense of oneness with the universe, does not view the natural world as a separate entity at all. Other ideas have evolved from a greater ecological understanding of human dependence on the natural world, as well as a realization of how little is known about its potential benefits, or the harms that may result from its destruction. These 
constructions view nature as the wild other of deep ecology, as Gaia, a self-regulating system, or as biodiversity. Deep ecology argues for the idea of self-realization, and an understanding of the inappropriateness of the dichotomy of the relationship between self and nature. Wild ecosystems are important to Gaia's functioning and provide for animal welfare and protect endangered plant species. Wild nature is also a laboratory for scientific study of these ecosystem processes as a comparative measure of land health.

A different group of utilitarian constructions described by Soule posits nature as a playground for physical recreational pursuits, as an object of aesthetic appreciation for its scenery and wildlife, or as a spiritual and divine place for psychological healing where we can experience the cosmic order. This latter construction suggests an ambivalence towards civilization, a critique of progress and growth, and a need for balance. Wilderness offers solitude instead of the social and freedom rather than order. Such statements echo the settlement myths in which wilderness is historically important and part of America's national character, a symbol of freedom, a heritage value (Leopold 1925; Stegner 1969).

Finally, many defenders of wilderness say that it simply has intrinsic value independent of human valuations. Its very existence is reason enough to preserve it. If this is true, then wilderness needs no other arguments articulated in its defense. Another group of scholars takes exception to these arguments in defense of the idea of wilderness, if not with the existence of wilderness itself. William Cronon's (1996) wide-ranging deconstruction of the idea of wilderness in his essay The Trouble 
with Wilderness provides the most-noted recent criticism, although he is certainly not the first to take such an approach (see Birch 1990; Callicott 1991a). Cronon argues that wilderness is not so much a place in the real world but a socially constructed concept. The ideas and perceptions that humans hold about nature distort our view of reality, and objective observation of the natural world is not possible. The central paradox of the idea of wilderness is that humans are separate from nature, and our very presence keeps nature from being wild. The two simply cannot coexist. This dichotomy privileges wild nature, and allows us to disregard and dismiss any environment that is not this wild and natural place. Impacts on the environment resulting from gtowth, consumption, and pollution are acceptable in these less-thanwild places. Cronon contends that a nostalgia for an existence before modern industrial society has resulted in the idea of saving places as wilderness, as vestiges of the past to be enjoyed as an escape from the modern world.

These social constructivists object to the idea of wilderness on other grounds. Callicott (1991a) says nature is no longer natural and pristine since humans have manipulated the landscape for thousands of years by the use of fire, hunting, and agriculture. The pristine myth of Pre-Columbian North America has had holes punched in it by William Denevan (1992), yet others (Vale 1998) have argued that this humanized landscape is in itself a myth. Callicott also makes the related argument that the wilderness idea simply does not recognize that change is a constant in nature, and that one moment in time, one type of nature, cannot be preserved. Thomas Birch (1990) argues that wilderness areas are manifestations of human control over nature 
and the wild, in a word, prisons. The State that draws the boundaries around the wilderness area is itself the greatest force for the destruction of wild nature.

Striking a note of balance, James Proctor (1996) suggests that we need to accept a paradox of thinking: that nature is at once a social construction and a reality that exists beyond the boundaries of those social constructions. As Ed Abbey puts it, "The boundary around a wilderness area may well be an artificial, self-imposed, sophisticated construction, but once inside that line you discover the artificiality beginning to drop away; and the deeper you go, the longer you stay, the more interesting things get" $(1977,230)$.

\section{Wilderness in the Wilderness Act.}

The implications of the legal definition of wilderness are more directly pertinent to this study than these abstract discussions. The Wilderness Act of 1964 succeeded in creating a new category of public land, defined in Section 2(c) as "an area where the earth and its community of life are untrammeled by man, where man himself is a visitor who does not remain." The act then proceeds to establish the two basic criteria necessary for federal land to be considered wilderness: (1) "generally appears to have been affected primarily by the forces of nature, with the imprint of man's work substantially unnoticeable" and (2) "has outstanding opportunities for solitude or a primitive and unconfined type of recreation." In addition wilderness areas must be at least five thousand acres, or of a sufficient size to make their preservation in an unimpaired state practicable. 
Mark Woods (1998) notes that the two main requirements for wilderness, naturalness and solitude, are diametrically opposed and create a paradox for the federal land management agencies charged with defining wilderness areas with lines on a map. Naturalness is a biocentric requirement implying intrinsic value, and the solitude is an anthropocentric requirement of utilitarian value.

Naturalness can itself be defined several ways. An ironically "purist" approach to naturalness is commonly employed by the Forest Service and Bureau of Land Management, and supported by industrial interests. That is, the only land that qualifies as wilderness is that which has never seen any man-made intrusions. If this argument is accepted, and opponents are armed with the knowledge that almost all lands in the country have seen some level of human impact, then little land can qualify as wilderness. A contrasting definition recognizes that land can recover from relatively insubstantial intrusions, even if it is not completely natural in the present. In this latter argument, a sense of continuity from past naturalness to future naturalness is an important factor (Maskit 1998). Of course, naturalness is also based on perceptions, and so will vary considerably with one's knowledge or mental images of a landscape.

The most common human imprints on the landscape in most areas under consideration for wilderness designation are roads, and roadlessness is thus the foremost component of naturalness. Section 4(c) of the Wilderness Act explicitly states that there shall be "no permanent road within any wilderness area designated by this Act." However, no definition of a road was written until the passage of FLPMA. In the BLM's Wilderness Inventory Handbook (1978) the following statement, quoted 
from the legislative history of FLPMA, serves to define a road: "The word 'roadless' refers to the absence of roads that have been improved and maintained by mechanical means to insure relatively regular and continuous use. A way maintained solely by the passage of vehicles does not constitute a road." This definition predates the explosion of off-highway vehicle use in the 1990's and has been subject to much debate; little work is needed to create or maintain a route in arid environments with open terrain, where off-highway vehicles can drive almost anywhere.

The human solitude requirement of the Wilderness Act also has a number of interpretations. Federal agencies have again generally made a strict definition that solitude is simply loneliness or seclusion; land is judged by its potential for isolation or screening by topography or vegetation (Woods 1998). Outside sights and sounds can also negatively influence this sense of aloneness. Others such as Vest (1987) feel a completely different interpretation is needed to reflect the cultural meanings and intent of the terminology. Wilderness solitude is a communion with wild nature, an aesthetic experience fostered by the landscape. This is similar to Nash's description that "wilderness is ultimately a feeling about a place, a state of mind that varies from person to person..." $(1982,384)$. One can find these two different interpretations within the BLM's own wilderness evaluations. One writer commented that views of unnatural Lake Powell detract from feelings of solitude. Another author notes that views of development at Natural Bridges National Monument actually enhance feelings of solitude because of the knowledge of the impossibility of crossing the terrain to get there (BLM Utah 1986). Woods (1998) argues that a way out of the 
subjectivism of this requirement is to note that only opportunities for solitude are required, and that solitude is dependent of the existence of the naturalness requirement in the first place. The solitude requirement then becomes secondary to the naturalness requirement.

As the poet Gary Snyder (1990) notes, the wild is usually defined by what it is not. Wildness is not described as a self-defining, autonomous, dominant presence of natural forces, but as an absence of human influence. Even so, the words of the Wilderness Act have been said to "define wilderness in an ideal, almost poetic, sense" (Vest 1987, 303). It is of little surprise that this highly subjective language has led to much confusion and debate. 


\section{THE BLM WILDERNESS INVENTORIES: A HISTORY}

\section{The "Bureau of Livestock and Mining" Looks for Wilderness}

The Bureau of Land Management in the Department of the Interior manages 262 million acres, more than ten percent of the land in the United States, and more than any other land management agency. Most of these lands are located in the western United States. Comprised mainly of grasslands and deserts, the BLM's domain is the once forgotten lands that seemed to have no useful purpose for settlement or resource extraction. The BLM administers these lands within a framework of laws, the most important of which is the Federal Land Policy and Management Act of 1976. In FLPMA, the BLM has a comprehensive and systematic mandate for the first time in its history. $A$ wilderness review of all BLM lands is part of that mandate.

Historic Roots of the BLM. Ironically, what is now a land management agency started in land disposal. In 1812, Congress established the General Land Office in the Department of the Treasury to oversee the disposition of newly acquired federal lands. As the 19th century progressed and settlement expanded westward, a wide variety of

laws, such as the Homestead Act of 1862 and the Hardrock Mining Law of 1866, were enacted to encourage settlement and economic use of these western territories. By the end of the $19^{\text {th }}$ century, concern over the condition of the public lands in the West resulted in policy changes that for the first time encouraged the conservation of natural resources (lackson 1995). But even after the so-called closing of the frontier in 
the 1890's, the West remained the only part of the country where many of these historic processes continued to play out. Large tracts of land in the West remained public as an accident of history and geography.

In the arid West, homesteading by necessity changed from farming to ranching, and the public lands served as a grazing commons. The Forest Service was first to regulate grazing within its forest reserves. Later, the Taylor Grazing Act of 1934 established the Grazing Service to manage the unreserved (and overexploited) public rangeland. The Grazing Service allotted privileges based on carrying capacity and historic levels of use, imposed fees, and established grazing districts with advisory boards of the interested parties. At the same time, unclaimed federal land was withdrawn from homesteading except in Alaska and Washington (Loomis 1993). In 1946, the Grazing Service was merged with the General Iand Office to form the Bureau of Land Management within the Department of the Interior. This new land management agency was fundamentally different from the Forest Service and the National Park Service. Instead of acting as a proprietor of lands within welldefined boundaries with few inholdings, the BLM managed federal lands interspersed with state sections and private property (Fairfax 1984). When the BLM was initially created, over 2,000 unrelated and often conflicting laws directed the administration of these remaining public lands. Although the BLM made an attempt at multiple-use management, land management was primarily based on one dominant use, typically livestock grazing or mining. In 1964, the BLM received a formal multiple-use mandate with the passage of the short-lived Multiple Use Classification Act. However, not until 
the passage of FLPMA in 1976 did the BLM get a well-defined mission from Congress equivalent to the legislation underpinning the Forest Service and the National Park Service (Loomis 1993).

The Organic Act of the BLM. As would be expected for such a comprehensive piece of legislation, FLPMA had many provisions. The vestiges of the BLM's origin were retired with the repeal of all remaining land disposal laws, and a declaration that federal lands would remain in public ownership. FLPMA defined multiple-use management as "management of the public lands and their various resource values so that they are utilized in the combination that will best meet the present and future needs of the American people." A framework of national, regional, and local plans was established. Mineral leasing and grazing restrictions were modified. But the biggest changes for the BLM would prove to be the act's environmental protection provisions. Besides mandating the establishment of areas of critical environmental concern with special management provisions, FLPMA required the BLM to conduct a wilderness inventory and make recommendations for wilderness designation by 1991. All lands were off limits to new development until they were determined to not have wilderness characteristics (Loomis 1993).

A multidisciplinary approach to land management that required the input of biologists and ecologists as well as resource and recreation specialists was also new to the agency. The BLM had already demonstrated difficulty in shedding its "Bureau of Livestock and Mining" roots in attempting to comply with the National Environmental Policy Act (NEPA) of 1969. NEPA requires that all federal actions be 
evaluated in terms of their potential impact on the environment, within a framework of multidisciplinary analysis and public involvement. The BLM issued programmatic environmental impact statements (EIS's) for grazing and mining rather than sitespecific EIS's, and was successfully sued by the National Resources Defense Council for not meeting the requirements of NEPA (Loomis 1993). Implementing the environmental protection requirements of FLPMA, especially the wilderness inventory and subsequent recommendations, was to be equally difficult for the agency. The Wilderness Inventory. In the late 1970's the BLM began its three-phase wilderness review. This process consisted of an inventory, followed by a study of the identified candidate areas, and finally a recommendation to Congress for wilderness designation. BLM Director Frank Gregg wrote that,

"The wilderness program and interim management policy should be in context with BLM policy of multiple use and sustained yield. The first responsibility of Bureau personnel is to establish the conditions under which all users at every level can participate in decision making. The basic thrust is a team approach where all resource interests can participate. The concept of wilderness forever is a serious philosophical commitment." (BLM Utah 1979a).

As Watkins comments, the BLM "met its wilderness assignment with a kind of surly" institutional resentment that caused it to overlook or disqualify many areas that a more objective investigation would have found to be entirely appropriate..." $(2000,96)$. The inventory itself was divided into two segments, an initial inventory and an intensive inventory.

The BLM released a wilderness inventory handbook in September of 1978 that set the standards for determining wilderness characteristics. During this phase of the process, only the wilderness characteristics of the land were to be considered, such as 
naturalness, opportunities for solitude, and primitive and unconfined recreation. The inventory was to be completed within two years. In Utah, the initial inventory began in December of 1978 and results were released in April of 1979, and 17 million of the 22 million acres of BLM land in Utah were eliminated from wilderness consideration (BLM Utah 1979a). The BLM based this initial assessment on maps, existing information, and the knowledge of BLM personnel, not on fieldwork, with the goal being removal from consideration any land that clearly and obviously did not meet the criteria of the wilderness inventory handbook. In San Juan County, about seventy-five percent of the 2 million acres of BLM land were released from study.

By November of 1979, the intensive inventory was completed for Utah (BLM Utah 1979b). A year later, a final report was released in which 2.6 million acres of the inventoried land were designated as wilderness study areas (BLM Utah 1980). In San Juan County, the BLM intensively inventoried 384,910 acres and recommended 214,910 acres as WSAs. Including two existing primitive areas, Dark Canyon and Grand Gulch comprising an additional 84,800 acres, the BLM recommended a total of eleven WSAs. Several notable regions of San Juan County were not recommended because of potential uranium mining, including Mancos Mesa and the lands surrounding Natural Bridges National Monument. Davis Canyon east of Canyonlands, site of a proposed nuclear waste depository, was also excluded, as was spectacular Arch Canyon thanks to the presence of a jeep trail.

In conducting its intensive inventory, the BLM did not consider simply the wilderness characteristics of the land, but also resource development potential, 
aesthetics, and other criteria, effectively usurping the job of Congress. In the process, the agency often violated its own policy as set forth in its wilderness inventory handbook. BLM personnel surveyed many units with aerial photographs or by helicopter, without on-the-ground evaluation. Large expanses were often deemed lacking in opportunities for solitude because they lacked vegetation. Other areas were dropped completely even though impacts around the perimeter could have been accounted for by boundary adjustments. Janet Ross, a member of the original inventory team, described how many recommendations from the field were overturned later,

"In every way, I was thrown road blocks as I tried to do the job I was hired to do. Not just by local special interests but by the BLM itself ... Many areas I fieldchecked myself and KNOW qualify for wildemess designation were disqualified as they traveled upward in the State Office." (199.5)

It became abundantly clear that despite the prescriptions of FLPMA, the on-theground implementation of the law was still at the discretion of the BLM. And this BLM was still the old "Bureau of Livestock and Mining."

Backlash: Sagebrush Rebellion and the Birth of Uncompromising Advocacy

Nobody, neither resource users nor environmentalists, was happy with the BLM inventory. Those who felt their livelihoods depended on access to public lands expressed dismay at even the prospect of BLM land being "locked up" and made unavailable for use. On the other hand, environmental groups were convinced that the BLM had excluded many lands with wilderness characteristics, simply because they coincided with sites for potential development. This displeasure would continue to be 
expressed by both sides as the BL.M progressed through the last two phases of the wilderness review process: analysis and recommendation.

Sagebrush Rebellion. Even before the inventory stage of the wilderness review was completed, the so-called sagebrush rebellion had commenced. A coalition of western politicians and resource user groups organized resistance against a number of federal land management policies, and key amongst them was wilderness preservation. This modern incarnation of previous rebellions ovet federal restrictions on water rights, logging, and grazing represented a clash between economic and social use of public lands. By 1979, Utah Senator Orrin Hatch and Nevada Representative Jim Santini introduced bills to Congress calling for transfer of BLM land to the states. Within a year, state legislation claiming BLM land passed in Nevada, Utah, Wyoming, New Mexico, and Arizona. These efforts generated tremendous debate but ultimately no tangible consequences. The success of the sagebrush rebellion turned out to be a raised awareness of the depth of opposition to federal land management, and the need for local residents to have a significant say in how public lands are used (Graf 1990).

The most prominent local Utah politician of the sagebrush rebellion was Calvin Black, a San Juan County Commissioner. Black was also a rancher and owned a uranium mine near Mancos Mesa (Graf 1990). He had been actively involved in the movement to establish the Payment in Lieu of Taxes program for rural counties with nontaxable federal land. Black echoed voices from the past by proclaiming against "colonialism of the West" by the federal government. In response to the very idea of a wilderness inventory, he threatened that (unnamed) citizens were considering acts of 
violence on public lands in danger of wilderness designation, and "people might get hurt." Black argued that the county already had more than its fair share of parks, monuments and recreation areas. Many potential wilderness areas had valuable mineral deposits, and designating an area wilderness would result in "backpackets" overrunning the land and "trying to bring the county to its knees economically"' (quoted in McPherson 1995, 360).

In the late 1970 's and early 1980 's, many county residents envisioned another economic boom, and the specter of wilderness designation was the only apparent obstacle. However, the uranium and petroleum boom proved to be short-lived, and it had nothing to do with the wilderness issue. In 1980, San Juan County's mining sectot provided 36 percent of the total jobs in the county. By 1988 mining employment had essentially disappeared with the collapse of uranium and petroleum prices (SUWA 2003). Even Calvin Black did not envision a return of a mining boom in San Juan County, and he placed his hopes in a tourism boom that was just beginning (Wheeler 1988b). Cattle ranching remained the only traditional economic activity that might be influenced by wilderness designation.

From UWA to SUWA. The environmentalists were also not pleased with the BLM's inventory and a quick response was needed. In August of 1981, the Utah Wilderness Association (UWA) appealed to the Interior Land Appeals Board (IBLA) to reinstate 925,000 acres that had been dropped from the intensive inventory. The IBLA eventually ordered a temand inventory of 814,000 of the acres under appeal. By October of 1983, the BLM added 560,000 acres, making for a total of 3.2 million actes 
of wilderness study areas. A second UWA appeal to the IBLA was made in July of 1984 for 225,000 acres dropped from the remand inventory, and the IBLA added back 77,000 of the acres under appeal (Goodman and McCool 1999). In San Juan County, the 51,000 acres of Mancos Mesa were added to list of wilderness study areas after appeal. Figures 8 and 9 show the distribution of wilderness study areas across the state and within San Juan County at the end of the appeals.

The controversy over the BLM wilderness inventory in Utah did not go unnoticed at the national level. From June of 1984 through July of 1985, the House Public Land Subcommittee chaired by Representative John Seiberling held oversight hearings on the BLM wilderness review. He noted how areas dropped from the inventory coincided with coal fields, oil/gas exploration, and other possible development. Seiberling eventually requested Interior Secretary Donald Hodel to take a second look at the BLM inventory, especially in Utah. The Department of the Interior replied that the inventory was as accurate and consistent as possible and that no lands would be added (UWC 1990).

While the debate over the BLM wilderness inventory continued, the first wilderness bill for the state of Utah had passed. The 1984 Utah Wilderness Act designated 750,000 acres of Forest Service land as wilderness, mostly in the Uinta Mountains. This bill included Dark Canyon/Woodenshoe Canyon in the Manti-LaSal National Forest in San Juan County. The Utah Wilderness Association (UWA), 
Figure 8. Utah Wilderness Proposals: 1985

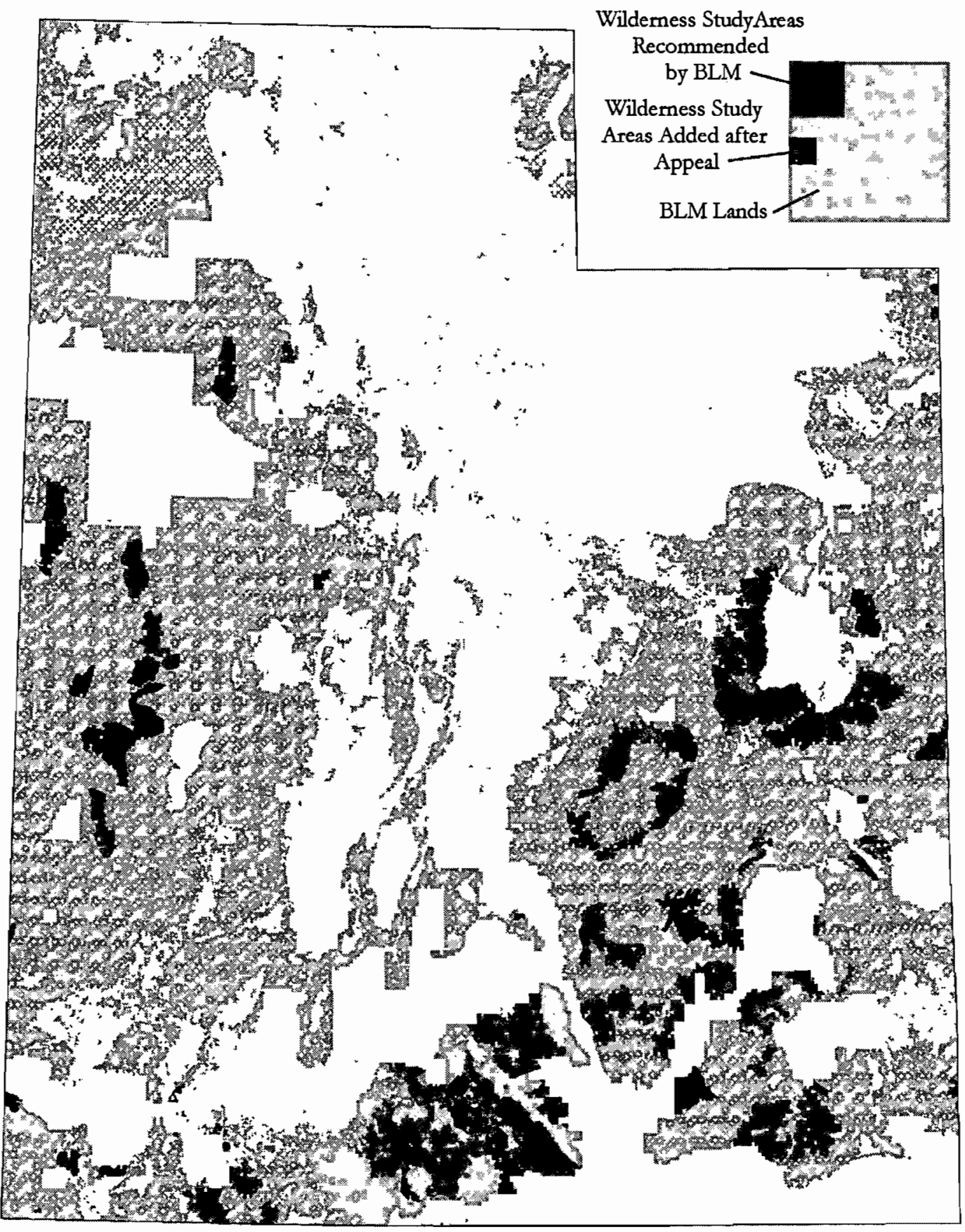




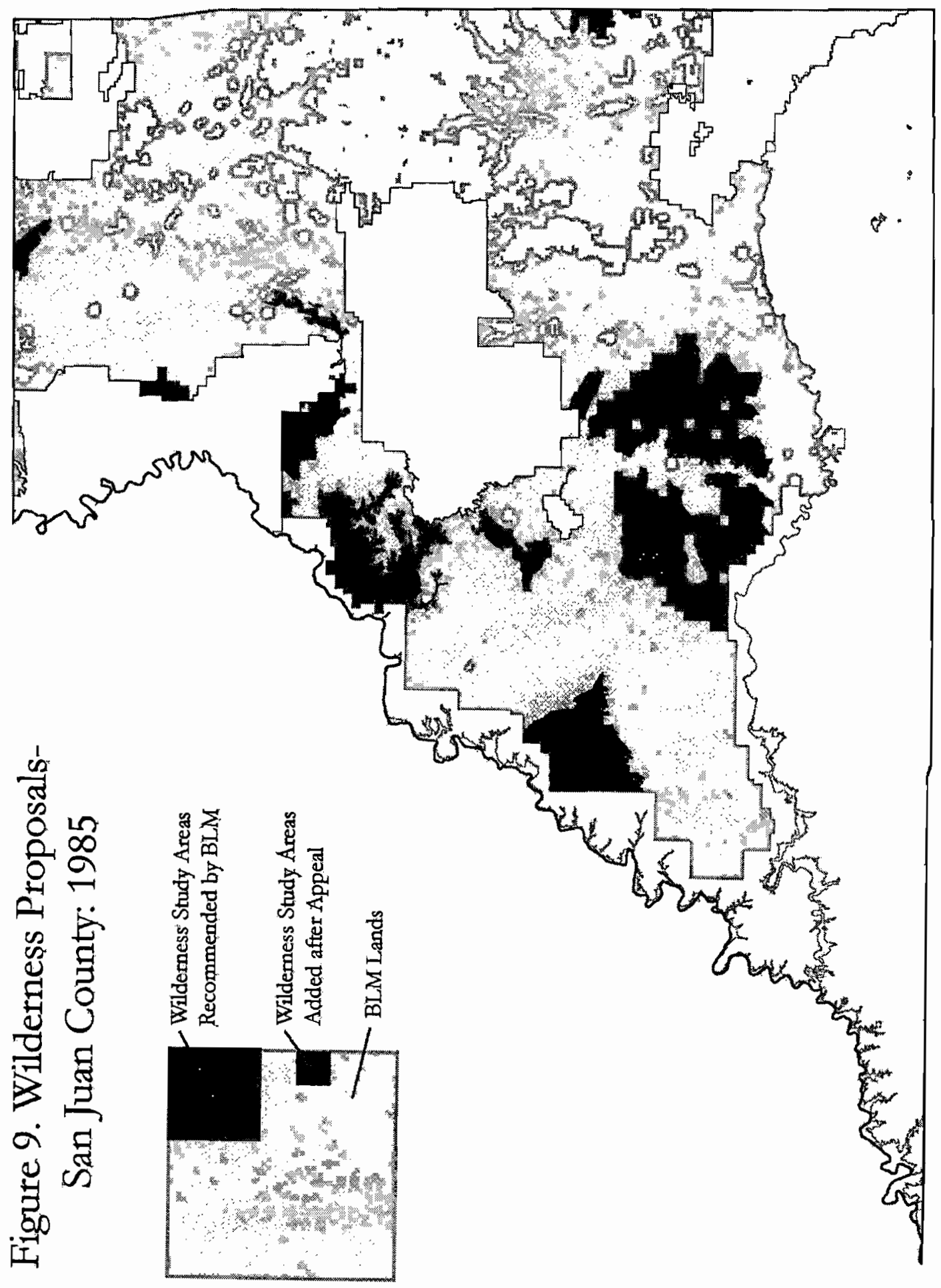


founded in 1979 , negotiated this compromise bill with state legislators, starting from their own 1.6 million-acre original proposal. Although this was not a particularly large amount of protected land, UWA coordinator Dick Carter noted philosophically that "A wilderness today is worth more than a wilderness ten years from now" (quoted in Goodman and McCool 1999, 220). The UWA promptly proceeded to develop a 3.8 million-acre wilderness proposal of its own for BLM by March of 1985.

The UWA also tried to develop a regional approach for BLM land. The idea was to avoid the problems it faced with negotiating the 1984 Forest Service bill: making tradeoffs between different areas with different concerns that resulted in loss of potential wilderness. Such an approach would avoid comparing scenic areas with those that were ecologically important, and would work within a smaller set of issues than was being considered at the state level. A similar approach had been taken for wilderness designation on BLM land in the so-called Arizona Strip, part of the Colorado Plateau in Northern Arizona. The Arizona Wilderness Act of 1984 designated 394,000 acres of wilderness on mainly BLM land, while releasing 672,000 acres from study. This bill also established two BLM wilderness areas that cross the border into Utah: Paria Canyon-Vermilion Cliffs and Beaver Dam Mountains. The regional-compromise approach was highly popular with conservatives in Congress, and Utah Senators Jake Garn and Orrin Hatch cosponsored it. Even Calvin Black testified in favor of this approach stating "this novel approach to solving the wilderness dilemma... has greatly lessened many of the concerns and much of the 
distrust felt by many members of southern Utah" (quoted in Goodman and McCool $2000,230)$

However, a number of other environmental groups in Utah objected to the UWA regional plan. The Sierra Club insisted on a larger acreage, noting that whatever was proposed would become the upper limit in negotiations. The Southern Utah Wilderness Alliance (SUWA), newly formed in 1984, felt that it was important to nationalize the debate instead of negotiating with the Utah congressional delegation and local politicians, another point of difference with the UWA. If the sagebrush rebellion was a backlash against the wilderness inventory, then SUWA would be the backlash against the sagebrush rebellion (Wheeler 1988a).This dissatisfaction with the UWA approach, combined with the end result of the 1984 Forest Service bill, eventually resulted in the formation of the Utah Wilderness Coalition (UWC) in 1985. The UWC combined the resources of thirty-five different environmental groups (but not the UWA) to contest the BLM wilderness inventory. The Executive Committee of the UWC consisted of SUWA, the Utah Chapters of the Sierra Club and the Wilderness Society, and the Wasatch Mountain Club. This new coalltion soon came up with its own proposal for 5.1 million acres of wilderness on BLM lands.

The Wilderness Review: Analysis and Feedback. The BLM finally completed work on the second phase of its wilderness review in Utah, a study of the candidate areas, by releasing a draft environmental impaçt statement (DEIS) in February of 1986. The DEIS included a number of possible alternatives, including a preferred alternative: 1.9 million acres recommended for wilderness designation. At this stage of 
the process, criteria other than wilderness characteristics were to be considered. Besides impacts on energy and mineral resource values and other socioeconomic factors, the BLM also evaluated the geographical distribution and diversity of wilderness areas. From March through May of 1986, the BLM held open houses to discuss the DEIS, and received 4,496 comments: $21 \%$ against wilderness, $44 \%$ in support, and 35\% neutral (BLM Utah 1990c). Criticism of this analysis came from all corners.

The National Park Service questioned the BLM's methodology and even how the boundaries of study areas were determined. They concluded that it was not obvious that topography, ecology, recreation use patterns, viewsheds, watersheds, and human use were taken into consideration. The National Park Service recommended that holistic and comprehensive land use planning be developed in conjunction with its own adjacent lands, citing studies that showed the importance of undeveloped public lands adjacent to national parks. These lands contribute to the national park experience; the presence of wilderness can be enjoyed without its active use. The Environmental Protection Agency (EPA) stated that it was unclear why the final recommendations were made for each study area. The recommendations left the impression that grazing, mining, and economic factors were the prime considerations. The EPA suggested that a factor be developed to evaluate reasonable economics and feasibility for developing minerals, instead of the BLM's practice of simply relying upon ratings of favorability and certainty. The EPA also recommended that solitude be considered as an interrelationship of size, screening, configuration, and other 
factors, noting that the BLM did not develop a thorough rationale for this attribute and relied too much on vegetation screening (BLM Utah 1990c).

Utah counties developed a "consolidated local government response to the BLM DEIS" (BLM Utah 1990c). In San Juan County's letter in support of this coordinated position, Calvin Black states that

"We are concerned that the areas of public land be protected, but designation of acres of wilderness does not adequately achieve protection while allowing the majority of the public to have use of these lands. These lands must be protected without risking the impediments to local economic pursuits that are represented by wilderness designation." (BLM Utah 1990c)

Among a cornucopia of complaints in the "consolidated response", the counties argued that wilderness designation would limit the extraction of natural resources, restrict grazing privileges and developments, and conflict with local plans that did not recognize the existence of wilderness. Showing little restraint themselves, the county governments claimed that "Wilderness designation without restraint could well seal the fate of many of Utah's rural economies. Wilderness management is the most restrictive, exclusionary land management mode ever devised for the public domain" (BLM Utah 1990c). Approaching the question from another angle, the counties felt that there were other (unstated) designations that could protect wilderness values. They argued that the very existence of areas that qualify as wilderness indicated that there is no risk of "man's imprint" and no need for wilderness protection. Finally, the counties noted a lack of fairness and geographical balance in the BLM's recommendation, since so many lands under consideration lie in southern Utah (BLM Utah 1990c). 
Another group that took issue with the BLM's recommendation for wilderness designation was the Utah Public Lands Multiple Use Coalition (UPLMUC). This group is comprised of separate associations of farmers, cattlemen, wool growers, foresters, manufacturers, miners, oil drillers, and other so-called taxpayers. In a notable change of thetoric from the sagebrush rebellion a few years earlier, the UPLMUC stated that the traditional multiple-use management by the Forest Service and the BLM had been outstanding. Wilderness areas existed because of the agency's sound management. However, according to the UPLMUC, wilderness could reduce jobs, or at least make for lower-paying jobs. Four out of ten negative impacts of wilderness listed in the coalition's response singled out 'backpackers' as part of the problem. These backpackers were the only (and very small) group of nonelected officials that actively supported wilderness, the only tourists that wilderness would attract, the only ones rich and physically fit enough to enjoy wilderness, and the potential destroyers of the wilderness by their very presence. This coalition of user groups knew that most Utahns, and certainly most elected officials, believed there is already enough wilderness in Utah (BLM Utah 1990).

The Wilderness Review: Recommendations. More than four years later, in November of 1990, the BLM released the final environmental impact statement for Utah. This seven-volume document was followed by a Final Report in October of 1991, which ended the inventory just before its fifteen-year deadline. In the final analysis, the BLM looked at seven different alternatives (BLM Utah 1990a). A Manageability option, which accounted for existing land use claims, would have 
recommended eighty percent of the WSA acreage as wilderness. A Paramount Wilderness Quality option eliminated most potential resource conflicts but also more than half the land under consideration. Two small proposals, the Regionally Representative and Small Cluster options, identified single areas or groups of areas with unique physical and biological attributes. Both of these options recommended less than thirty percent of the WSA acreage as wilderness, and would establish only 14 and 12 wilderness areas, respectively.

The preferred BLM recommendation falls somewhere among all of these more explicitly defined options, a compromise of 1.9 out of the 3.2 million acres studied and 69 out of 82 possible areas. Tables II and III summarize the criteria used for the evaluations of wilderness study areas in San Juan County. Table II outlines the descriptive characteristics for each WSA, and Table III lists potential multiple uses (BLM Utah 1990b). Three of the twelve wilderness study areas in San Juan County, Cheesebox Canyon, Squaw and Papoose Canyon, and Cross Canyon, were not recommended by the BLM for wilderness designation.

Claire Ginger (2000) has studied BLM wilderness EIS's as argumentative discourse and finds little connection between the data used for analysis and the final recommendations. However, she notes that during the time between the draft and final EIS's, the framing of the wilderness issue shifted from a resource-program approach to one employing a place-specific evaluation of wilderness study areas. This change reflects new arguments, consideration of new data, and even different decision-making processes. The agency by necessity had developed its own wilderness 
TABLE II. WILDERNESS STUDY AREAS IN SAN JUAN COUNTY: CHARACTERISTICS

\begin{tabular}{|c|c|c|c|c|c|c|}
\hline WSA & $\begin{array}{c}\text { Size } \\
\text { (acres) }\end{array}$ & $\begin{array}{l}\text { Solitude } \\
(\%)\end{array}$ & $\begin{array}{l}\text { Visual Resources (1) } \\
(\%)\end{array}$ & $\begin{array}{l}\text { Vegetation (2) } \\
(\%)\end{array}$ & EIS Options (3) & Special Characteristics \\
\hline Bridger Jack Mesa & 5290 & 50 & Cl. B-100 & PJ-90/ BR-10 & BLM & $\begin{array}{l}\text { ACEC } \\
\text { Inaccessible to OHVs }\end{array}$ \\
\hline Butler Wash & 24350 & 100 & $\begin{array}{l}\text { Cl. A-47 } \\
\text { Cl. B-10 Cl. C-43 }\end{array}$ & $\begin{array}{l}\mathrm{PJ}-71 / \mathrm{BR}-26 / \mathrm{SB}-2 / \\
\mathrm{DS}-1\end{array}$ & $\begin{array}{l}\text { BLM/ } \\
\text { Paramount }\end{array}$ & $\overline{A C E C}$ \\
\hline Cheesebox Canyon & 15410 & 60 & Cl. $A-100$ & $\begin{array}{l}\mathrm{PJ}-41 / \mathrm{BR}-52 / \mathrm{DS}-6 / \\
\mathrm{G}-1\end{array}$ & Not recommended & $\begin{array}{l}\text { Scenic Corridor ACEC } \\
\text { Desert bighorn sheep habitat }\end{array}$ \\
\hline Cross Canyon (4) & 1010 & $\ldots$ & ---- & $\mathrm{PJ}-92 / \mathrm{DS}-8$ & Not recommended & \\
\hline Dark Canyon & 68030 & 100 & $\begin{array}{l}\text { Cl. A-91 } \\
\text { Cl. B-9 }\end{array}$ & $\mathrm{PJ}-50 / \mathrm{DS}-49 / \mathrm{SB}-1$ & $\begin{array}{l}\text { BLM/Paramount/ } \\
\text { Regional/Small cluster }\end{array}$ & $\begin{array}{l}\text { ACEC Primitive Area } \\
10 \text { miles perennial streams }\end{array}$ \\
\hline Fish/Owl Canyons & 49650 & 96 & $\begin{array}{l}\text { Cl. A-60 } \\
\text { Cl. B-40 }\end{array}$ & $\begin{array}{l}\text { PJ }-59 / \text { DS-28/ BR- } \\
10 / \text { SB-3 }\end{array}$ & $\begin{array}{l}\operatorname{BLM}(\mathrm{p}) / \\
\text { Paramount }(\mathrm{p})\end{array}$ & $\begin{array}{l}9490 \text { acres not recommended } \\
5 \text { miles perennial streams }\end{array}$ \\
\hline Grand Gulch & 107920 & 98 & $\begin{array}{l}\text { Cl. } A-54 \\
\text { Cl. B-45 Cl. C-1 }\end{array}$ & $\begin{array}{l}\text { PJ-74/ DS-10/ BR-9/ } \\
\text { SB-7 }\end{array}$ & $\begin{array}{l}\text { BLM/Paramount/ } \\
\text { Regional/Small cluster }\end{array}$ & $\begin{array}{l}2400 \text { acres not recommended } \\
\text { Primitive Area }\end{array}$ \\
\hline Indian Creek & 6870 & 100 & Cl. $A-100$ & BR-75/DS-25 & BLM & $\begin{array}{l}4 \text { miles perennial stream } \\
\text { Desert bighorn sheep habitat }\end{array}$ \\
\hline Mancos Mesa & 51440 & 90 & $\begin{array}{l}\text { Cl. B-90 } \\
\text { Cl. C-10 }\end{array}$ & DS-100 & $\begin{array}{l}\text { BLM/Paramount(p)/ } \\
\text { Regional (p)/Small cluster (p) }\end{array}$ & $\begin{array}{l}\text { Inaccessible to most OHVs } \\
\text { Desert bighom sheep habitat }\end{array}$ \\
\hline Mule Canyon & 5990 & 86 & $\begin{array}{l}\text { Cl. A-53 } \\
\text { Cl. B-47 }\end{array}$ & $\mathrm{PJ}-57 / \mathrm{BR}-42 / \mathrm{SB}-1$ & BLM & \\
\hline Road Canyon & 54820 & 87 & $\begin{array}{l}\text { Cl. A-56 } \\
\text { Cl. B-44 }\end{array}$ & $\begin{array}{l}\text { DS-42/ PJ }-29 / \mathrm{BR}- \\
25 / \mathrm{SB}-4\end{array}$ & $\begin{array}{l}\text { BLM }(p) / \\
\text { Paramount }(p)\end{array}$ & 2580 acres not recommended \\
\hline $\begin{array}{l}\text { Squaw/Papoose } \\
\text { Canyons (4) }\end{array}$ & 6680 & $\begin{array}{ll}---- \\
--1\end{array}$ & $\cdots$ & $\mathrm{PJ}-100$ & Not recommended & \\
\hline
\end{tabular}

Source: BLM Utah State Office 1990, Utah BLM statewide wildemess final environmental impact statement.

(1) Class $A$ : Areas in which landform, water form, and vegetation patterns are of unusual or outstanding visual quality. Class $B$ : Areas in which features contain variety, but are not outstanding. Areas lack dominating features. Class $\mathrm{C}$ : Areas in which features have little variety and become monotonous.

(2) Vegetation- PJ- pinyon/juniper, DS- desert shrub, SB- sagebrush, G- grass, BR- barren rock

(3) Environmental Impact Statement options include all or no wilderness, BLM recommended, paramount wilderness quality, regionally representative, small clusters. (p) indicates that part of the WSA is included in the EIS option.

(4) Not studied in the Utah statewide wildemess EIS. Contiguous areas in Colorado are now in Canyons of the Ancients NM. 
TABLE III. WILDERNESS STUDY AREAS IN SAN JUAN COUNTY: POTENTIAL MULTIPLE USES

\begin{tabular}{|c|c|c|c|c|c|c|}
\hline WSA & Impacts & $\begin{array}{l}\text { Estimated } \\
\text { Visitor } \\
\text { Days }\end{array}$ & $\begin{array}{l}\text { Cultural } \\
\text { Resources } \\
\text { (1) }\end{array}$ & $\begin{array}{l}\text { Grazing AUMs } \\
\# \text { (Operators) } \\
\text { (2) }\end{array}$ & $\begin{array}{l}\text { Afineral Claims } \\
\text { \# (acres) } \\
\text { Favorability/Certainty }\end{array}$ & $\begin{array}{c}\text { Oil/Gas Leases } \\
\text { (acres) } \\
\text { Favorability/Certainty }\end{array}$ \\
\hline $\begin{array}{l}\text { Bridger Jack } \\
\text { Mesa }\end{array}$ & Outside sights and sounds & $<100$ & ---- & $\ldots$ & $\begin{array}{l}68(1360) \\
\text { U,V-low/moderate } \\
\text { Mn-low/high Potash-low }\end{array}$ & $\begin{array}{l}\text { None } \\
\text { Low/very low }\end{array}$ \\
\hline Butler Wash & $\begin{array}{l}3 \text { state sections } \\
\mathrm{OH} \text { use in vicinity }\end{array}$ & 1150 & $13(860)$ & $206(1)$ & $\begin{array}{l}\text { None } \\
\text { U,V-low/high Potash-low }\end{array}$ & $\begin{array}{l}3(440) \\
\text { Low }\end{array}$ \\
\hline $\begin{array}{l}\text { Cheesebox } \\
\text { Canyon }\end{array}$ & $\begin{array}{l}\text { One 4-mile way } \\
\text { Outside sights and sounds }\end{array}$ & 1000 & $12(600)$ & $157(1)$ & $\begin{array}{l}98(1960) \\
\text { U,V,Cu-low/high }\end{array}$ & $\begin{array}{l}\text { None } \\
\text { Low/very low }\end{array}$ \\
\hline $\begin{array}{l}\text { Cross Canyon } \\
\text { (3) }\end{array}$ & $\begin{array}{l}3 \text { ways } \\
\text { Nearby oil/gas development }\end{array}$ & $\overrightarrow{\cdots+--}$ & $\begin{array}{l}\text { Large number of } \\
\text { sites expected }\end{array}$ & ---- & $\begin{array}{l}\text { None } \\
\text { Moderate }\end{array}$ & $\begin{array}{l}36(8875) \\
\text { High potential }\end{array}$ \\
\hline Dark Canyon & $\begin{array}{l}7.5 \text { miles of ways } \\
\text { OHV use/Grazing }\end{array}$ & 17200 & $68(3400)$ & $775(2)$ & $\begin{array}{l}\text { None } \\
\mathrm{U}, \mathrm{V} \text {-low/moderate }\end{array}$ & $\begin{array}{l}\text { None } \\
\text { Low }\end{array}$ \\
\hline $\begin{array}{l}\text { Fish/Owl } \\
\text { Canyons }\end{array}$ & $\begin{array}{l}5 \text { state sections -- } 22 \text { miles of ways } \\
\text { Woodcutting/Grazing }\end{array}$ & 6850 & $61(8140)$ & $1073(15)$ & None & $\begin{array}{l}32(1880) \\
\text { Low }\end{array}$ \\
\hline Grand Gulch & $\begin{array}{l}4 \text { state sections -- } 20 \text { miles of ways } \\
\text { Woodcutting/Grazing }\end{array}$ & 22800 & $580(12360)$ & $1930(8)$ & None & $\begin{array}{l}8(1060) \\
\text { Low }\end{array}$ \\
\hline Indian Creek & $\begin{array}{l}\text { Grazing } \\
<1 \text { mile of ways } \\
\text { OHV use in vicinity }\end{array}$ & $<100$ & 12 & $39(2)$ & $\begin{array}{l}\text { None } \\
\text { U,V-low Mn-low/high } \\
\text { Potash-moderate }\end{array}$ & $\begin{array}{l}\text { None } \\
\text { Low }\end{array}$ \\
\hline Mancos Mesa & $\begin{array}{l}7 \text { state sections } \\
25 \text { miles road }\end{array}$ & 1200 & $17(1205)$ & $514(1)$ & $\begin{array}{l}176(3520) \\
\mathrm{U}, \mathrm{V} \text {-moderate/low }\end{array}$ & $\begin{array}{l}10(22656) \\
\text { Moderate/low }\end{array}$ \\
\hline Mule Canyon & $<1$ mile of ways & 240 & $37(700)$ & $37(1)$ & None & None \\
\hline Road Canyon & $\begin{array}{l}6 \text { state sections -- } 7 \text { miles of ways } \\
\text { Woodcutting/Grazing }\end{array}$ & 2000 & $112(5445)$ & $1450(19)$ & $8(160)$ & $\begin{array}{l}12(504) \\
\text { Low }\end{array}$ \\
\hline $\begin{array}{l}\text { Squaw/Papoose } \\
\text { Canyons (3) }\end{array}$ & $\begin{array}{l}1 \text { vehicle way } \\
\text { Nearby oil/gas development }\end{array}$ & ----- & $\begin{array}{l}\text { Large number of } \\
\text { sites expected }\end{array}$ & $\cdots$ & $\begin{array}{l}\text { None } \\
\text { Moderate }\end{array}$ & $\begin{array}{l}6(1586) \\
\text { High potential }\end{array}$ \\
\hline
\end{tabular}

Source: BLM Utah State Office 1990, Utah BLM statewide wilderness final environmental impact statement.

(1) Known archaeological sites and estimated numbers of unexcavated sites. Estimates are based on similar settings.

(2) AUM is an animal unit month: the amount of forage required by one cow or five sheep for one month.

(3) Not studied in the Utah statewide wilderness EIS (part of Colorado study). 
expertise. Ginger states that recognition and acceptance of wilderness as a land-use category slowly became institutionalized within the BLM over the fifteen-year process of inventory, evaluation, and recommendation.

Wilderness at the Edge. While the BLM was working out its final recommendations, the Utah Wilderness Coalition was conducting its own comprehensive wilderness inventory of BLM lands. The results were published in Wilderness At The Edge: A Citizen Proposal to Protect Utab's Canyons and Deserts (UWC 1990). This 400-page document was, in effect, an environmental impact statement containing reams of information, cost/benefit analyses, and detailed maps of each proposed wildemess area. It left the impression that these citizens knew the wild lands of Utah at least as well as the BLM. In the process, the Southern Utah Wilderness Alliance, as the major player in the UWC, had supplanted UWA as the preeminent defender of wilderness in Utah. SUWA's philosophy of "uncompromising advocacy" was far removed from the compromise of the soon-to-be defunct UWA.

The UWC proposal served as the basis for a bill introduced in Congress by Utah Representative Wayne Owens in March of 1989, which recommended 5.1 million acres of wilderness. Figures 10 and 11 show a comparison of this new proposal, the UWA proposal, and the BLM WSAs for both the state and San Juan County. Immediately, a companion bill was introduced by Utah Representative James Hansen recommending 1.4 million acres. Neither bill came to a vote before the political landscape changed following the 1994 election. 
Figure 10. Utah Wilderness Proposals: 1990

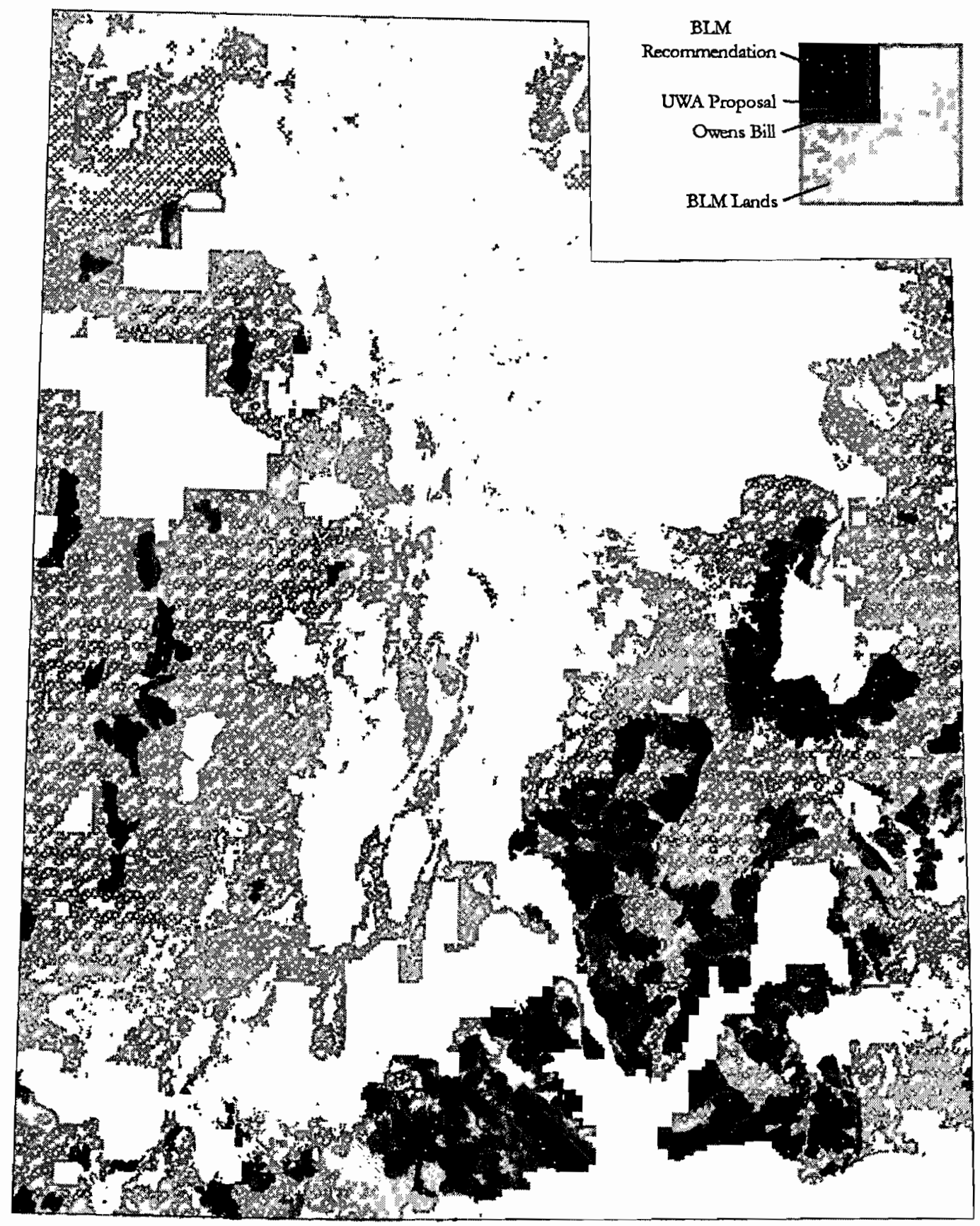


Figure 11. Wilderness ProposalsSan Juan County: 1990

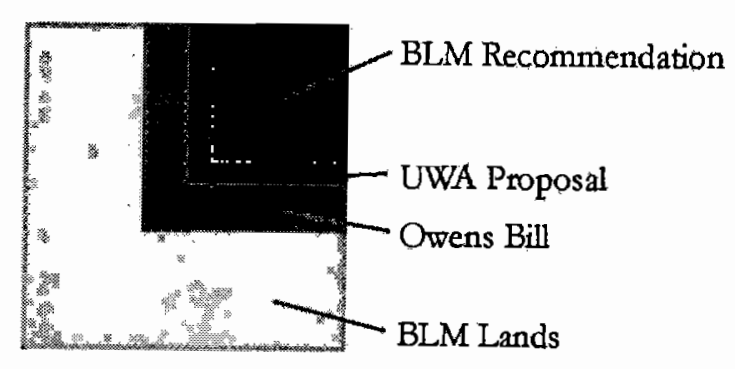




\section{The Election of a Republican Congress: A Door Opens}

The election of 1994 swept an anti-environmental Republican majority into Congress. Representative James Hansen of Utah became the new chairman of the House Subcommittee on National Parks, Forests, and Public Lands, from which all wilderness legislation originates. The Utah Congressional delegation saw an opportunity to take care of the "wilderness problem" once and for all (Watkins 2000, 99).

(Anti-) Wilderness Proposals. Action was swift, as Governor Mike Leavitt instructed Utah counties to develop wilderness proposals by April of 1995. Rural counties throughout the West had recently been emboldened by the development of the so-called county supremacy movement. In 1990, Catron County in New Mexico passed an ordinance that required local approval of all federal actions in the county, and threatened federal officials with arrest if they did not consent. By 1992, dozens of counties throughout the West had passed similar ordinances (Davis 1997). As with the sagebrush rebellion, the benefit was an increased attentiveness to local needs, not in the actual enforcement of the ordinance.

Although initially reluctant to recommend any wilderness, the San Juan County commissioners soon got on board and crafted their own wilderness proposal. They recognized Dark Canyon, Butler Wash, Indian Creek, and two thirds of Mancos Mesa as wilderness areas totaling 133,560 acres. They also recommended a 197,920 acre National Conservation Area incorporating Grand Gulch, Road, and Fish and Owl Creek Canyons to protect archaeological resources. The county's proposal report 
stated that "most working professional archaeologists believe wilderness is not the best tool to manage cultural resources" (San Juan Record 1995b).

Although environmental groups participated in public hearings about the county wilderness proposals, they had little influence with state and local politicians. Displeased with the process, representatives of SUWA were not shy about why they did not like to work with local government. "They don't even know what is and isn't allowed in wilderness. . There is no basis for rational dialogue with them (the commissioners)" stated Ken Rait during the development of the county proposal (San Juan Record 1995a). After several more meetings, Rait concluded that "These guys hate wilderness. They are selfish, they are short-sighted, and they are bent on stealing America's wilderness legacy" (San Juan Record 1995b).

The Utah Congressional delegation doubled the size of the counties' proposal of just less than one million acres, ending up with a proposal similar to the BLM's recommendation to Congress. As Governor Leavitt said,

"I support the consensus proposal announced by the congressional delegation. The bill reflects our commitment to a fair, balanced approach to protecting land. I am especially pleased that Utah's 'crown jewels' have been protected as wilderness under this bill.” (San Juan Record 1995c)

Mike Matz, executive director of SUWA, had a different assessment of the Utah congressional delegation proposal, protesting that "Utah's politicians are playing a colossal practical joke on the people of Utah and their fellow Americans" (quoted in San Juan Record 1995c). The proposal became the Utah Public Lands Management Act and was introduced by Hansen in the House as H.R. 1745 in June of 1995. It was soon also submitted by Utah Senator Orrin Hatch as S. 884. Besides recommending 
1.8 million acres of the wilderness, the bills also contained "hard release" language. A provision stated that lands not designated as wilderness in this bill could never be considered as such again. New development would be allowed inside the established wilderness areas. This clause preempted previous allowances for development that were based only on valid existing rights at the time of wilderness designation.

America's Redrock Wilderness Act. At the same time, a very different wildemess bill, H.R. 1500, was introduced in Congress as America's Redrock Wilderness Act. This latest version of the 1989 Owens bill now covered 5.7 million acres. New York Congressman Maurice Hinchey had assumed sponsorship of the legislation after Owens was defeated in a bid for a Senate seat. One example of the level of interest in the wilderness issue in Utah was the release of Testimony: Writers of the West Speak on Behalf of Utab Wilderness (Trimble and Williams 1996). In this small book, twenty-one writers appealed to Congress to support wilderness in general and America's Redrock Wilderness Act in particular, and to oppose the Utah congressional bill. One of those authors, Ann Weiler Walka, asks

"Why not acknowledge that there is something here more important to our beleaguered society than a marginal mine, an overgrazed permit? A great American myth is embodied in wild lands, and it is myth, ultimately that holds a people together." $(1995,17)$

Others, such as former Utah BLM director James Parker, spoke out against this latest citizens' proposal and in defense of the original BLM inventory, claiming that,

"The ill-conceived 5.7 million-acre proposal includes in its boundaries private homes and buildings, cultivated fields, chained areas, thousands of acres of private and school trust lands and other areas that cannot be designated as 
wilderness. It also includes hundreds of miles of roads, a major disqualifier for wilderness designation. Also included are oil and gas wells, hundreds of mining leases and mining claims, rights of way, etc. all of which would conflict with wilderness designation.

An experienced BLM manager, who is also a wilderness advocate, recently expressed the opinion that the passage of the 5.7 million-acrewilderness proposal would be a blatant affront to the National Wilderness Preservation System and would show total disregard for the intent of the Wilderness Act. I agree." (1995)

Unlike the Utah congressional bill, this modified Owens bill would never come to a vote. Figures 12 and 13 compare H.R. 1500 with H.R. 1745, the county proposal, and the BLM recommendation for both the state and San Juan County.

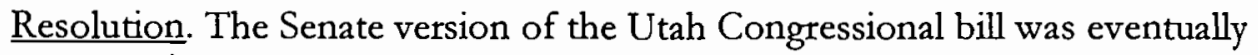
tacked onto an Omnibus Parks and Recreation Act in March 1996. Robert Armstrong, Assistant Secretary of the Interior for Lands, Minerals, and Management, wrote to Senator Bill Bradley of New Jersey that "far too little land is protected under this bill and too much land is released for development. In short, no one should be claiming the support of the Bureau of Land Management and its professional staff' (quoted in Watkins 2000, 102). A harbinger of changing institutional attitudes, this statement was made less than four years after the BLM had made a similar recommendation. Bradley successfully used a filibuster to defeat the bill. In his speech, Bradley echoed the sentiments of environmental groups by stating

"I know that some of my colleagues will argue that preservation of Utah's unique natural heritage is a matter best left to the state's own delegation with its considerable wisdom and considerable talent. In this case, I have to disagree. Wilderness is a gift we give to our children and grandchildren, a gift that once destroyed can never be reconstructed. The children of New Jersey deserve it, as much as the children of California or Colorado..." (quoted in Watkins 2000, 105) 
Figure 12. Utah Wilderness Proposals: 1995

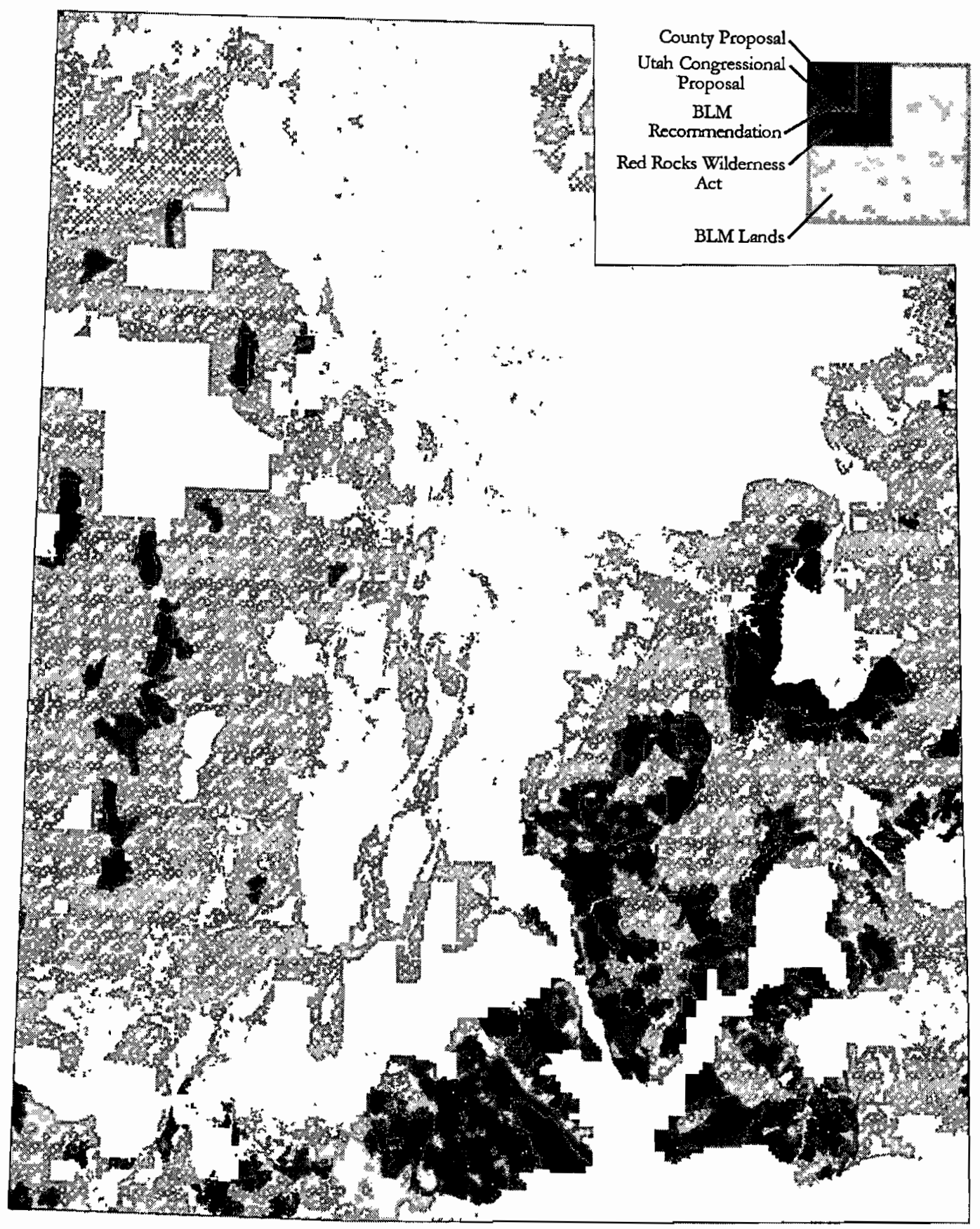


Figure 13. Wilderness ProposalsSan Juan County: 1995
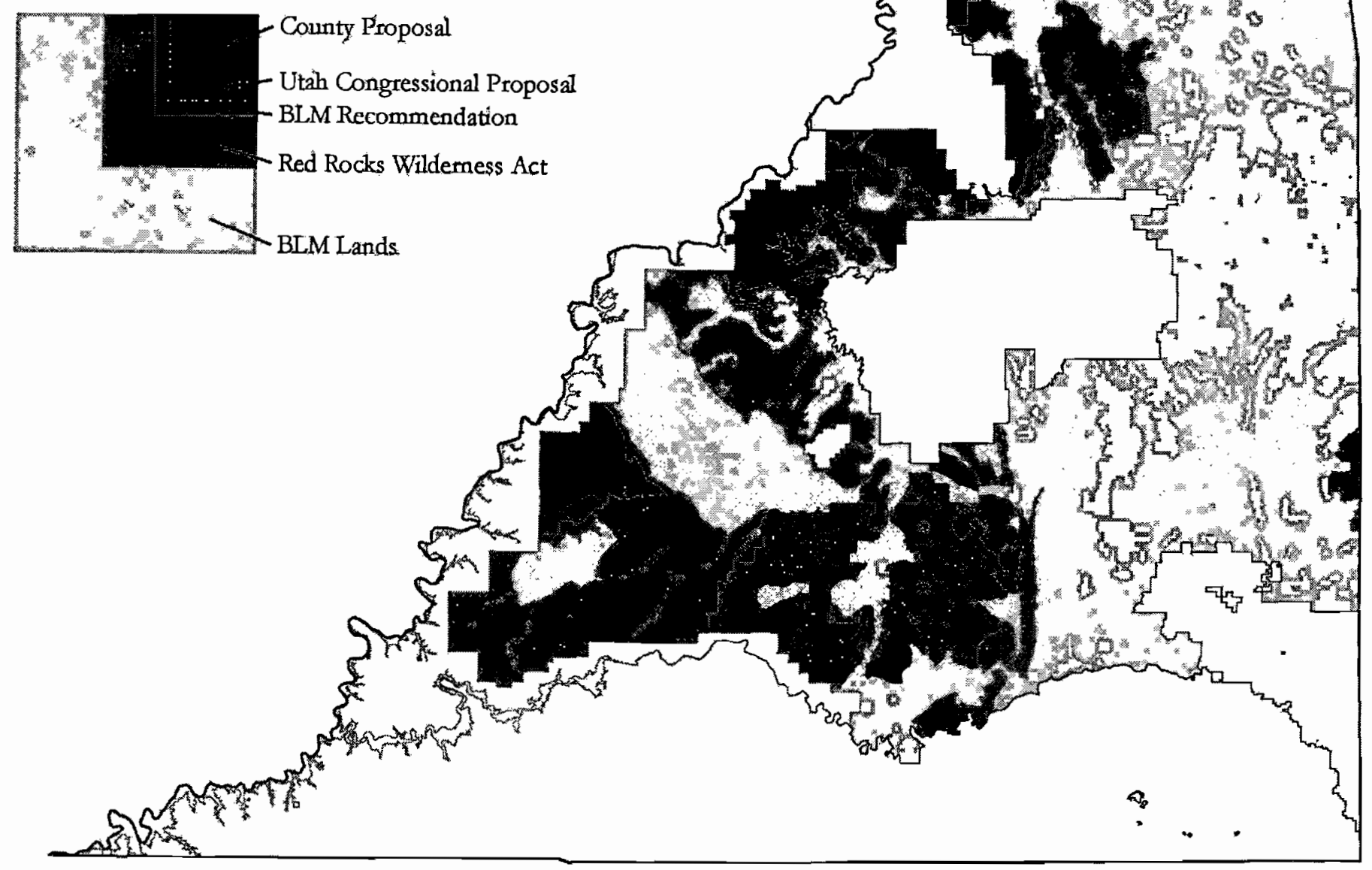
After this defeat in the Senate, Hansen pulled the House version of the bill before it ever came to a vote.

\section{The Greening of the BLM}

Over the course of a year, the tide had started to turn in favor of the environmentalists. In September of 1996 President Bill Clinton designated Grand Staircase-Escalante National Monument on 1.7 million acres of BLM land in southcentral Utah. (5) This one national monument was almost as large as the entire Utah Congressional wilderness proposal for the state. Some have claimed that the designation of the monument was a direct result of the polarized nature of the debate surrounding the Utah delegation's (anti-) wilderness bill (Goodman and McCool 1999). And more changes were to come.

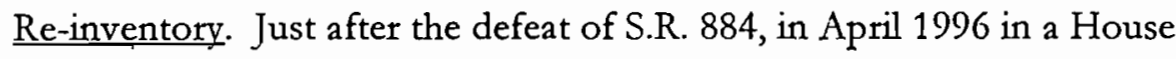
Resources Committee hearing, Hansen challenged Interior Secretary Bruce Babbitt that the de facto wilderness in H.R. 1500 did not exist. Babbitt took Hansen's challenge, and by June had ordered a re-inventory of Utah BLM lands. The reinventory excluded existing wilderness study areas and was limited to the remainder of land suggested as wilderness by the H.R. 1500. These lands were to be evaluated for wilderness chatacteristics only, and any recommendation for the creation of wilderness study areas or changes in land management policy would be the result of a separate process. In the interest of impartiality and objectivity, and in hopes of defusing the 
political nature of the debate, agency personnel from outside of state would conduct the re-inventory "guided" by Utah BLM personnel.

The state of Utah, the Utah Association of Counties, and the Utah State Institutional Trust Lands Administration sued to stop the re-inventory in October of 1996. They challenged the Secretary of the Interior's authority to conduct a second inventory, claiming that only the original inventory per Section 603 of FLPMA was valid. As a result of the lawsuit, a temporary restraining order was issued by a federal district court that stopped the re-inventory in midstream. Not until June of 1998 was the injunction overturned by the Tenth Circuit Court of Appeals. The court ruled that the language of Section 201 of FLPMA clearly allows for, in fact even requires the Secretary to

"...maintain on a continuing basis an inventory of all public lands and their resource and other values [which shall be] kept current so as to reflect changes in conditions and to identify new and emerging resources and other values... The preparation and maintenance of such inventory or the identification of such areas shall not, of itself, change or prevent change of the management or use of public lands."

Since inventories themselves did not result in any change in the way the BLM manages the land, the State and counties suffered no harm in the process and therefore lacked standing to sue. After the ruling, the re-inventory resumed and was completed in 1998 with the results published in early 1999 . In a remarkable turnaround from the original inventory, the BLM found that 81 percent of these lands originally excluded from consideration as wilderness actually had wilderness characteristics.

Everyone's a Land Manager: The County Responds. Not to be outdone, San Juan County also conducted its own survey of the re-inventory lands in 1998 and1999. 
In a cover letter for the county's comments about the re-inventory (San Juan County 1999), Commissioner Ty Lewis emphatically stated that,

"The basic premise of the San Juan County master plan is to maintain valued customs, varied cultures and community stability. You must give some thought and credence to the fact that you have challenged rural Utah's very core beliefs. You have challenged us spiritually, economically and culturally. This is exactly why the debate has gone on for so long and has been so passionately argued." (San Juan County 1999)

The county left no issue unargued in its comments. They put forth several discussion points about the nature of the re-inventory process, although they clearly misunderstand the process by which wilderness study areas are created. The first argument suggested that the on-going litigation of road definitions should be settled before addressing whether or not wilderness study areas should be designated. The second argument, despite a settled lawsuit to the contrary, questioned the very legality of the inventory. The county argued that FLPMA does not indicate that wilderness should be one of the multiple uses taken into account in resource planning. The Wilderness Act makes clear that wilderness designation is an entirely new type of reservation of public lands and not one of the multiple uses. In the third argument, the county objected to the re-inventory being made on the basis of the four criteria in the Wilderness Act alone without accounting for resource availability and economic impacts.

Anticipating the worst, the county made some just-in-case arguments. While not discrediting tourism, they still claimed that agriculture and mining are the foundation of rural economies. They argued for the creation of assistance programs as compensation for wilderness designation, the premise being the loss of potential 
revenue from mining. Although just presented as a series of broad statements with no detail as to how they might be administered, these ideas included training programs for displaced workers for such new jobs as tour guides and concessionaires, and larger payments in lieu of taxes, perhaps four to five times greater than current payments.

The county also questioned the practice of "cherry stemming" roads to create wilderness boundaries. A buffer zone around dead-end roads within otherwise wild areas is often excluded from the wilderness area rather than drawing the wilderness boundary back where the road begins. This creates a cherry-stem extension of developed land into the wilderness area. Whether this practice in fact creates wilderness where none exists is arguable, but the county argument that it detracts from a wilderness experience is a bit disingenuous. The county also expressed concern about solitude and the wilderness experience. The report states that "Many ranchers and miners will express that the idea that backpackers and recreationists have more negative influence on solitude than does (sic) other resource users" (San Juan County 1999).

Specific and detailed complaints about the re-inventory units included a laundry list of livestock corrals and ponds, old chainings, mining scars, oil/gas pads, and other human impacts that may or may not be substantially unnoticeable. The major objections can be divided into three main categories. First, possible mineral development is an issue for Mancos Mesa, Indian Creek, and the entire White Canyon complex (Cheesebox Canyon, Gravel and Long Canyons, and Fort Knocker Canyon). Second, oil and gas are known to exist in the vicinity of Squaw, Papoose, and Cross 
Canyons, and they "believe there is potential" for oil/gas developments for Mancos Mesa and Indian Creek. Third, county claims to roads are important for the units of Grand Gulch complex (including Fish and Owl Canyons and Road Canyon), Indian Creek, and especially Hart's Point. Other items of concern included woodcutting in the Grand Gulch complex, off-highway vehicle use in Indian Creek, grazing on the Dark Canyon Plateau, and access to the historic Hole-in-the-Rock trail in the Nokai Dome unit.

The comments contain no shortage of hyperbole. As far as the county is concerned, the White Canyon complex unquestionably did not meet the spirit or intent of the Wilderness Act. Its inclusion was ludicrous and there was no area less deserving. On the other hand, Indian Creek was labeled the biggest travesty of the reinventory in San Juan County. Several other units were labeled jokes for lacking scenic qualities and vegetative or topographic screening. Other than the pejorative language, these remarks could have been lifted from the documentation of the original inventory.

Surprisingly, several units were found to apparently be acceptable as wilderness, based on the general lack of commentary. These would be Dark Canyon, Butler Wash, Bridger Jack Mesa, and Nokai Dome. Protection of the cultural resources in the Grand Gulch Complex was considered necessary but should be done through the ACEC designation.

Everyone's a Land Manager: SUWA Responds. While the BLM re-inventory was occurring, SUWA was also conducting its own re-inventory. Volunteers evaluated 
all BLM lands in the state over a two and a half year period. The new citizens' wilderness invenfory was finished in 1998 and now included 9.1 million acres of potential wilderness. The majority of the new lands added to the original 5.7 million acres were in the westem desert, an area previously given little attention. Primarily due to off-highway vehicle impacts, a small amount (less than one percent) of the original lands deemed wilderness quality in the first citizens' inventory no longer qualified as wildemess. The new inventory was not publicly documented to the same level of detail as the one the previous one (SUWA 2003a). Representative Hinchey and Senator Richard Durbin of Illinois introduced the expanded America's Redrock Wilderness Act into Congress in 1999 as H.R.1732 and S.861. Figures 14 and 15 compare this new citizens' proposal with the BLM WSA's and the re-inventory recommendation for the state and San Juan County.

SUWA also submitted comments in response to the BLM re-inventory (SUWA 1999). Acknowledging that the re-inventory was fair and credible for the most part, the remarks were not extensive. Highlighting a lack of inter-agency cooperation, SUWA noted that parts of Mule/Arch Canyon were excluded even though they are contiguous with much larger roadless areas in Manti-LaSal National Forest. Also, the excluded northeast tim of Mancos Mesa had only faint mining scars "not recognizable as man-made scars to typical visitors to southeast Utah". SUWA is not immune to the overstatement characteristic of the wilderness debate, claiming that the exclusion of areas on Hart's Point was "the biggest gaffe in the entire re-inventory". 
Figure 14. Utah Wilderness Proposals: 2000

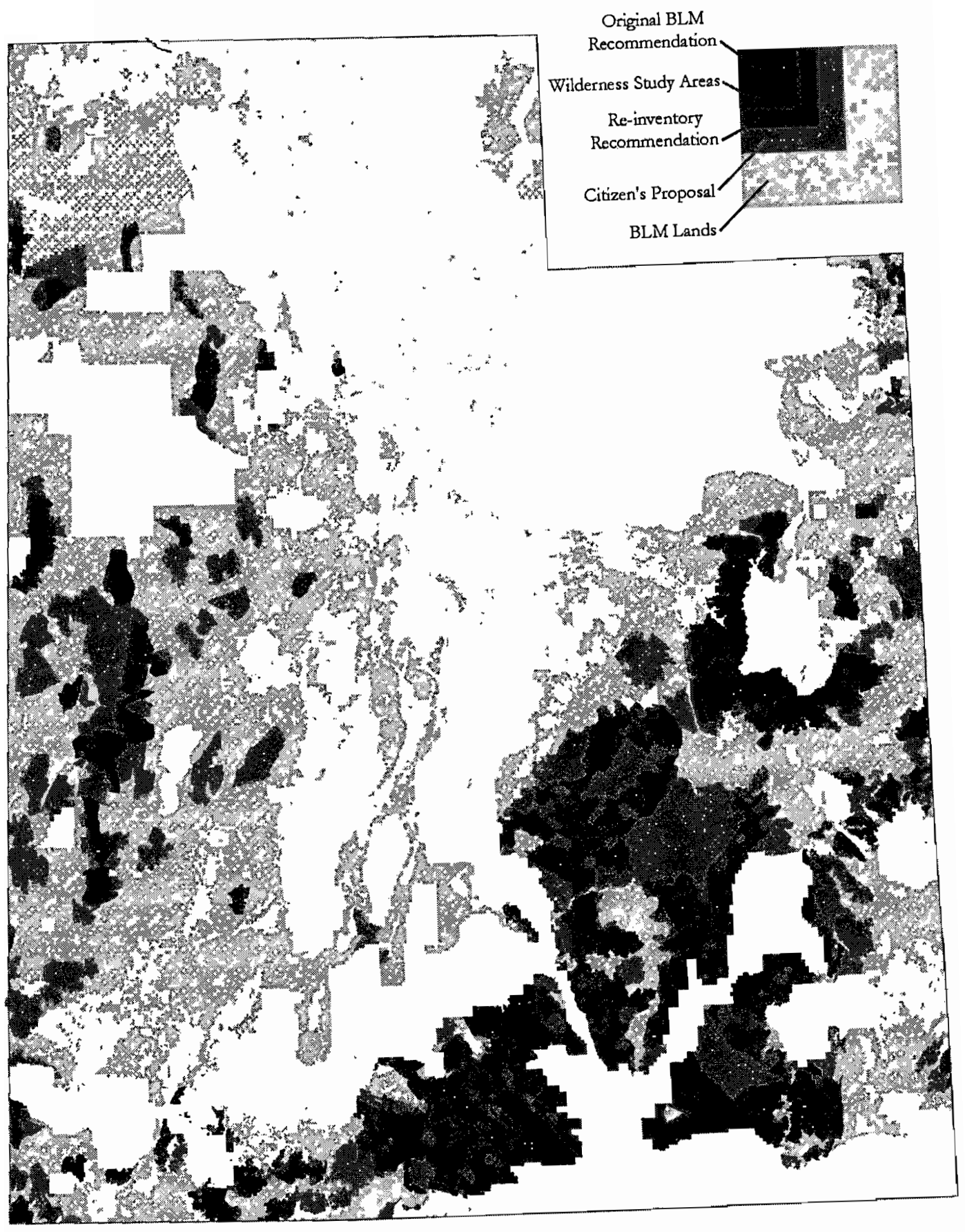


Figure 15. Wilderness ProposalsSan Juan County: 2000
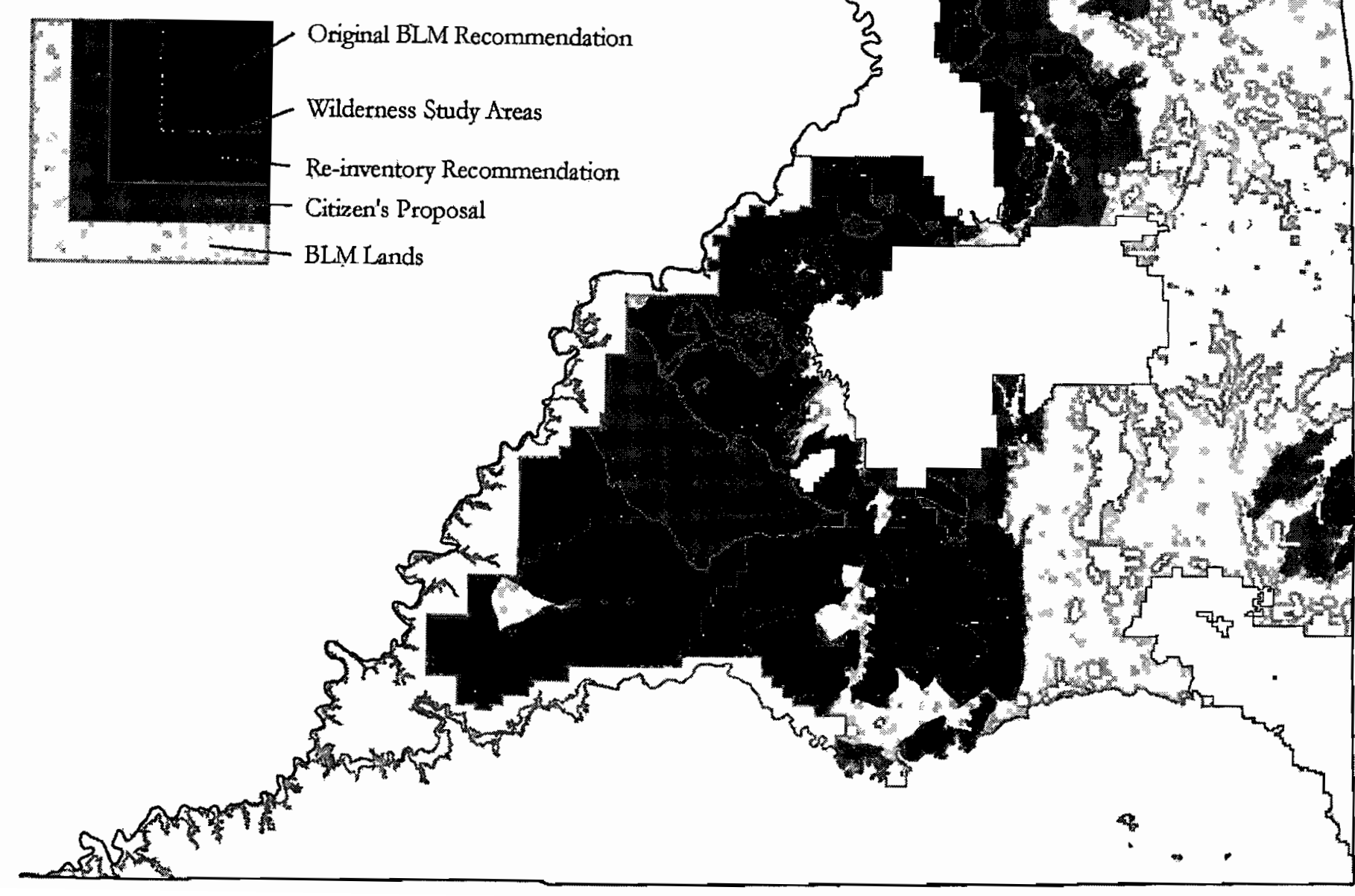
The remainder of SUWA's comments pertain to vehicular use of public lands. The changing economics of the rural west have made road claims and $\mathrm{OHV}$ use the newest and most important impacts on any potential wilderness lands. An obscure section of the 1866 mining law, Revised Statute 2477, provides simply that "the rightof-way for the construction of highways across public lands, not reserved for public uses, is hereby granted." R.S. 2477 was repealed as part of FLPMA, but local governments could still "claim" roads if they could prove their existence and regular use prior to 1976 . As noted earlier, roads must be mechanically constructed and mechanically maintained. On the surface, the issue is about access to resources and key transportation links. However, since roadlessness is one of the most important characteristics of a wilderness area, the designation of official roads is a powerful tool to prevent wilderness designation. Not surprisingly, these claimed "highways" include trails, reclaimed century-old mining wagon roads, jeep trails, and two-tracks that go nowhere in particular. More the 95 percent of the pending R.S. 2477 road claims in the United States can be attributed to just three counties in Utah, including San Juan (Goodman and McCool 1999).

OHVs have had unlimited access to BLM-administered lands for decades. Parallels to the unlimited use of the range for cattle grazing prior to the Taylor Grazing Act can be drawn. A similar sense of privilege has become associated with this usufruct right, and continued access is more important than any previously unknown environmental impacts or changing social values. Motorized use of public lands is now a "traditional" use. (6) 
If, as SUWA suggested, certain sections of routes were considered to be ways and not roads, much of the map of wilderness study areas and re-inventory study units could be redrawn. The size of the RSUs for Mule/Arch Canyon and Squaw/Papoose Canyons would be greatly enlarged and less likely to be excluded. Several roads in the White Canyon complex could be cherry-stemmed instead of considering them through routes, and this would create one large wilderness area extending from Natural Bridges National Monument to Glen Canyon National Recreation Area. Finally, if cherrystemmed routes that are just faint and insignificant ways with no mechanical maintenance were ignored, the potential impacts for Hart's Point, Dark Canyon, and Butler Wash would be reduced.

More Wilderness in San Juan County. Shortly after the completion of the reinventory, in March of 1999, the BLM released a notice of intent to prepare an EIS to evaluate possible designation of new wilderness study areas per Section 202 of FLPMA (BLM Utah 1999a). Wilderness study areas created under Section 202 are different than those created per Section 603 which authorized the original inventory. The latter can be removed only by Congress, while Section 202 WSAs can be created and removed by the BLM at any time. Based on the large volume of comments received about the re-inventory, by November the BLM had decided to take a regional approach and draft seven separate EIS's (BLM Utah 1999b). Minor revisions to the reinventory were made for the southeast region, which included San Juan and Grand Counties (BLM 2000), and then the first EIS was prepared for that region (BLM Utah 2002). If the Utah Wilderness Association was still in existence, it would have felt 
vindicated that the BLM had adopted the method of analysis the UWA had proposed fifteen years ago.

Table IV shows a summary of the BLM findings for the RSUs in San Juan County. The amount of land with and without wilderness characteristics (BLM 1999) and a breakdown of the alternatives are shown (BLM Utah 2002). The re-inventory found that 86 percent of the RSUs administered by the Monticello Field office in San Juan County met the requirements of the Wilderness Act for naturalness and solitude. In contrast to the alternatives explored in the first BLM wilderness inventory, even the development-oriented alternative recommends $85 \%$ of the land with wilderness characteristics to be managed as wilderness study areas. This is $73 \%$ of all land inventoried. The BLM preferred alternative recommends $92 \%$, or $79 \%$ of all land inventoried, and the only other alternatives are the obligatory all wilderness and no wilderness options. Implicit in this study is a reconsideration of the original BLM recommendation to Congress in 1991. Several of the newly recommended WSAs surround existing WSAs that the BLM did not recommend for wilderness designation in 1991, such as Cheesebox Canyon. This draft EIS has yet to be released, and as BLM staff have noted, is unlikely to be under the current administration (personal communication with BLM personnel 2002).

Table V lists the impacts, both real and potential, considered for each RSU during both the inventory and subsequent analysis (BLM Utah 2002). Unlike the original inventory, minor impacts were accounted for by redrawing boundaries instead of excluding entire units. These impacts were restricted to mesatops and included 
TABLE IV. RE-INVENTORY STUDY UNITS IN SAN JUAN COUNTY: BLM FINDINGS

\begin{tabular}{|c|c|c|c|c|c|}
\hline Study Unit & $\begin{array}{l}\text { Land with wilderness } \\
\text { characteristics } \\
\text { (acres) }\end{array}$ & $\begin{array}{l}\text { Land without wilderness } \\
\text { characteristics } \\
\text { (acres) }\end{array}$ & $\begin{array}{l}\text { Adjacent Lands (1) } \\
\text { (acres) }\end{array}$ & $\begin{array}{l}\text { Preferred Alternative } \\
\text { (\% recommended as } \\
\text { wilderness) }\end{array}$ & $\begin{array}{c}\text { Development Alternative } \\
\text { (\%recommended as } \\
\text { wilderness) }\end{array}$ \\
\hline Arch/Mule Canyon & $-\overline{-O}^{2}$ & 14860 & $-\cdots$ & --- & - \\
\hline Bridger Jack Mesa & 26400 & 4280 & 5290-WSA 61180-CNP & 99 & 99 \\
\hline Butler Wash & 3780 & 1040 & 24350-WSA 61180-CNP & 100 & 41 \\
\hline Cheesebox Canyon & 16400 & 2730 & 15410-WSA 5340-NBNM & 64 & 50 \\
\hline Comb Ridge & 14800 & 2600 & $\cdots$ & 80 & 80 \\
\hline Cross Canyon & 1800 & 790 & 12590-WSA & 11 & $\cdots$ \\
\hline Dark Canyon & 71800 & 1000 & $\begin{array}{c}\text { 68030-WSA } 18100-\mathrm{CNP} \\
45000-\mathrm{NF} 105980-\text { GCNRA }\end{array}$ & 100 & 99 \\
\hline Fish/Owl Canyons & 31610 & 2670 & 49650-WSA & 50 & 45 \\
\hline Fort Knocker Canyon & 13600 & ---- & ‥-- & 100 & 100 \\
\hline Grand Gulch & 55890 & 2990 & $\begin{array}{c}\text { 107920-WSA } \\
\text { 12850-GCNRA }\end{array}$ & 85 & 85 \\
\hline Gravel/Long Canyons & 42200 & $-\cdots$ & $-\cdots$ & 100 & 100 \\
\hline Harmony Flat & 10600 & 200 & 5340-NBNM & 75 & 75 \\
\hline Hart's Point & 19700 & 52500 & --- & 100 & 100 \\
\hline Indian Creek & 21640 & 3020 & 6870-WSA $105980-C N P$ & 96 & 96 \\
\hline Mancos Mesa & 71600 & 11600 & 51440-WSA & 100 & 99 \\
\hline Nokai Dome & 101400 & $-\cdots--$ & GCNRA & 99 & 99 \\
\hline Road Canyon & 17000 & 2410 & 54820-WSA & 89 & 89 \\
\hline San Juan River & 14700 & 600 & -...- & 66 & 66 \\
\hline Sheep Canyon & 5340 & :--- & 18600-GCNRA & $\cdot 100$ & 100 \\
\hline $\begin{array}{l}\text { Squaw/Papoose } \\
\text { Canyons }\end{array}$ & 4920 & 70 & $11290-W S A$ & 42 & $+\cdots$ \\
\hline
\end{tabular}

Source: BLM 1999, Utah wilderness inventory and BLM Utah State Office 2002, Utah wildemess study area draft environmental impact statement/draft plan amendment- Southeast region.

(1) WSA-Wilderness Study Area, CNP-Canyonlands National Park, NBNM- Natural Bridges National Monument, NF-National Forest, GCNRA-Glen Canyon National Recreation Area. 
TABLE V. RE-INVENTORY STUDY UNITS IN SAN JUAN COUNTY: CHARACTERISTICS

\begin{tabular}{|c|c|c|c|c|c|c|}
\hline Study Unit & $\begin{array}{c}\text { Reason Originally Excluded } \\
\text { (1) }\end{array}$ & $\begin{array}{l}\text { Current Issues } \\
\text { (2) }\end{array}$ & $\begin{array}{c}\text { State } \\
\text { Sections }\end{array}$ & $\begin{array}{l}\text { Wildlife } \\
\text { Habitat }\end{array}$ & $\begin{array}{l}\text { Minerals } \\
\text { (3) }\end{array}$ & $\begin{array}{c}\text { Oil/gas } \\
\text { Exploration (4) }\end{array}$ \\
\hline $\begin{array}{l}\mathrm{Arch} / \mathrm{Mule} \\
\text { Canyon }\end{array}$ & $\begin{array}{l}\text { Unit split by state section } \\
\text { Lack of vegetative screening }\end{array}$ & Jeep Safari route & 2 & & ---- & $\cdots$ \\
\hline Bridger Jack Mesa & $\begin{array}{l}\text { Partially eliminated during initial inventory } \\
\text { Lack of topographic screening or varied } \\
\text { terrain }\end{array}$ & $\begin{array}{l}\text { Adjacent private lands } \\
\text { Camping along roads }\end{array}$ & 6 & & High & ---- \\
\hline Butler Wash & Roads and chainings & & 4 & & $\cdots$ & Yes \\
\hline $\begin{array}{l}\text { Cheesebox } \\
\text { Canyon }\end{array}$ & $\begin{array}{l}\text { Mining impacts to surrounding areas } \\
\text { Drill pads and chainings }\end{array}$ & $\begin{array}{l}\text { Adjacent private lands } \\
\text { Woodcutting/Chainings } \\
\text { OHV use }\end{array}$ & 5 & $\begin{array}{l}\text { Desert bighorn } \\
\text { sheep }\end{array}$ & $+\cdots$ & $\overline{----}$ \\
\hline Comb Ridge & Eliminated before intensive inventory & $\begin{array}{l}\text { Utility Corridor } \\
\text { Camping }\end{array}$ & 3 & $\begin{array}{l}\text { Willow } \\
\text { flycatcher }\end{array}$ & $-\cdots$ & Yes \\
\hline Cross Canyon & $\begin{array}{l}\text { No strong support } \\
\text { Nearby oil/gas development and chainings }\end{array}$ & $\begin{array}{l}\text { Adjacent private lands } \\
\text { Chainings }\end{array}$ & 1 & & $\cdots+-$ & $\begin{array}{c}\text { Yes } \\
\text { Known deposits }\end{array}$ \\
\hline $\begin{array}{l}\text { Dark Canyon } \\
\text { (5) }\end{array}$ & $\begin{array}{l}\text { Partially eliminated during initial inventory } \\
\text { Roads, chainings, and } \\
\text { limited solitude in short open canyons }\end{array}$ & $\begin{array}{l}\text { Wildlife and livestock } \\
\text { developments } \\
\text { Camping at trailheads } \\
\text { OHV use } \\
\text { Chainings }\end{array}$ & 13 & $\begin{array}{l}\text { Mule deer } \\
\text { Desert bighorn } \\
\text { sheep }\end{array}$ & ---- & $\overrightarrow{\cdots---}$ \\
\hline $\begin{array}{l}\text { Fish/Owl } \\
\text { Canyons }\end{array}$ & $\begin{array}{l}\text { Partially eliminated during initial inventory } \\
\text { Roads and chainings }\end{array}$ & $\begin{array}{l}\text { Adjacent private lands } \\
\text { Camping } \\
\text { Woodcutting/Chainings }\end{array}$ & 11 & $\begin{array}{l}\text { Willow } \\
\text { flycatcher }\end{array}$ & $\cdots$ & Yes \\
\hline $\begin{array}{l}\text { Fort Knocker } \\
\text { Canyon }\end{array}$ & $\begin{array}{l}\text { Eliminated before intensive inventory for } \\
\text { mineral exploration impacts }\end{array}$ & & 2 & & ---- & $\cdots$ \\
\hline $\begin{array}{l}\text { Grand Gulch } \\
(6)\end{array}$ & Roads and chainings & Woodcutting/Chainings & & & $-\cdots$ & Yes \\
\hline $\begin{array}{l}\text { Gravel/Long } \\
\text { Canyons }\end{array}$ & $\begin{array}{l}\text { Eliminated before intensive inventory for } \\
\text { mineral production and exploration }\end{array}$ & Jeep Safari route & 12 & $\begin{array}{l}\text { Desert bighorn } \\
\text { sheep }\end{array}$ & High & ---- \\
\hline Harmony Flat & $\begin{array}{l}\text { No topographic screening or varied terrain } \\
\text { but good vegetative screening }\end{array}$ & Chainings & 1 & & ---- & -..-- \\
\hline
\end{tabular}


TABLE V. (CONTINUED)

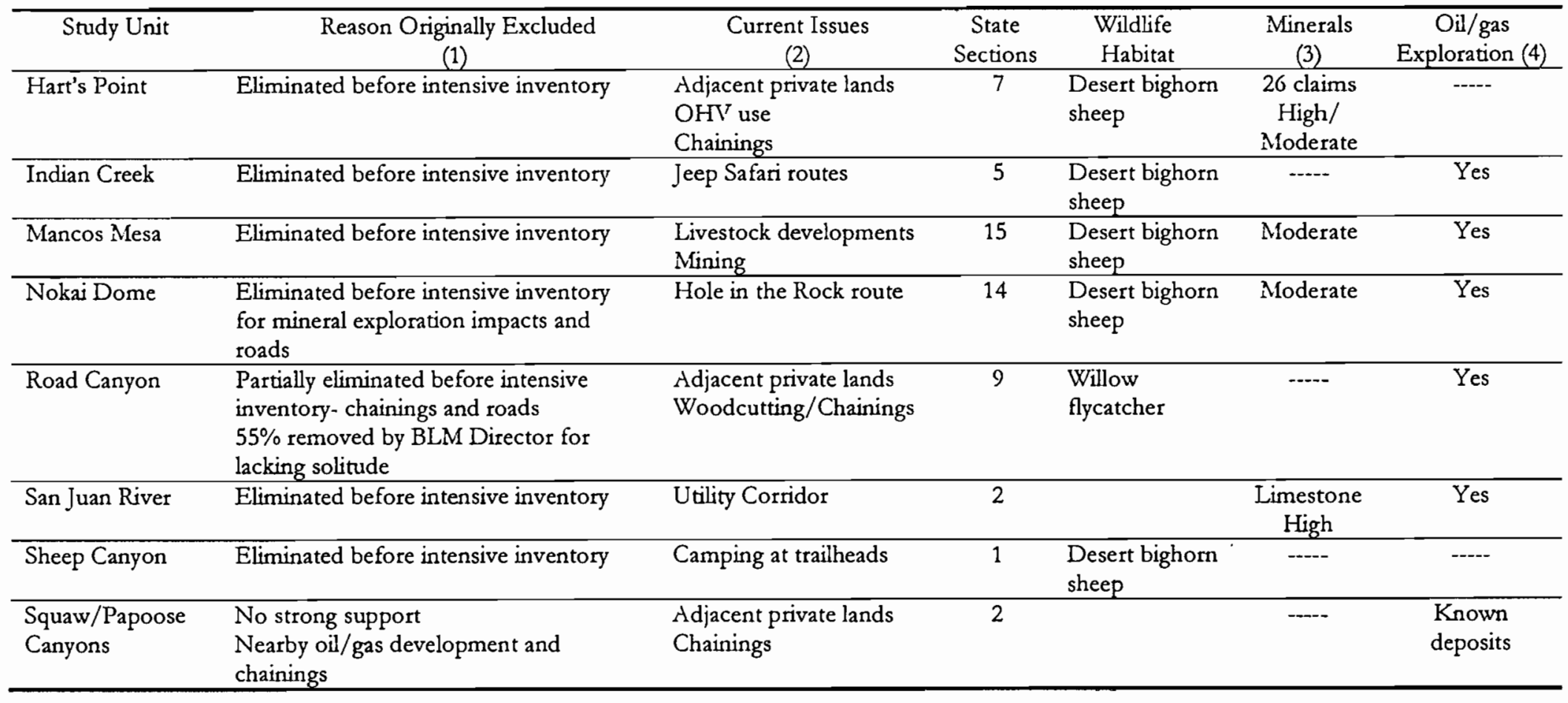

Source: BLM Utah State Office 2002, Utah wilderness study area draft environmental impact statement/draft plan amendment- Southeast region.

(1) Units eliminated during intensive inventory unless otherwise noted..

(2) Wildlife and livestock developments include reservoirs, fences, guzzlers, and a ten-mile pipeline for mule deer use on Dark Canyon Plateau due to high winter mortality rates.

(3) Deemed not an issue for analysis due to low likelihood for development in all but one potential WSA.

(4) Deemed not an issue for analysis due to low likelihood for development in all but two potential WSAs.

(5) Dark Canyon includes Sweet Alice Canyon, Middle Point, and the existing primitive area.

(6) Grand Gulch includes Pine Canyon, Sheiks Flat, Bullet Canyon, Slickhorn Canyon, Johns Canyon, and the existing primitive area. 
developments such as roads, drill pads and vegetative treatments. A long strip of the Mancos Mesa unit, in Red Canyon below the mesa itself, was removed from consideration due to mining impacts. Sections of the Indian Creek unit were removed from consideration because of off-highway vehicle impacts. Only two units, Hart's Point and Cheesebox Canyon, had large areas excluded for a variety of substantially noticeable impacts. One entire unit, Arch Canyon, was eliminated because its configuration consisted of several long, thin sections. divided by roads or ways, including a jeep trail down the center of Arch Canyon itself.

The analysis of the re-inventory reflected a different and much more sophisticated understanding of wilderness on the part of the BLM than the original review. In general, areas were considered as wilderness unless human impacts were substantial rather than as areas of resource development that became wilderness only if there was no economic interest. A number of issues were not even considered relevant for detailed analysis. Contrary to the county's wishful thinking, and based on a fifteen-year planning horizon, mineral development likelihood was deemed low for all RSUs except for the development of limestone in the San Juan River area. Oil and gas exploration had occurred in many of the RSUs but only two, Squaw and Papoose Canyons and Cross Canyon, both on the Colorado border, had known deposits in their vicinity. R.S. 2477 road claims and grazing allotments were considered separate land management issues with no bearing on wilderness recommendations.

The BLM took into account a different and broader set of community concerns about the use of public lands than during the first analysis. These included 
community expansion, utility corridors, special recreation permits, woodcutting, and developments for vehicle-based recreation, wildlife, and livestock. Environmental protection needs, such as watershed enhancements, were also considered. The most significant change from the previous analysis was that an evaluation of alternative resource availability was considered. The amount of resource available and its potential for development, its presence in other locations, and local and regional dependence on the resource were all weighed. In other words, each study area was not considered as a single entity, but evaluated in the context of the region.

Once again, the changing nature of the discourse of the re-inventory and subsequent analysis indicates continued institutional change within the BLM. The reinventory revealed a BLM capable of producing evenhanded, realistic, and balanced analyses of potential wilderness areas. Over the last fifteen years, the amount of wilderness designated on BLM-administered lands has slowly grown to 6.5 million acres, predominantly in California, Arizona, and Nevada (see Table VI). This is but a small fraction of the wilderness administered by the Forest Service, yet more than 16 million acres of wilderness study areas still remain throughout the West.

Whether this new regional approach could provide a solution to the debate about wilderness designation in Utah is another question. If subsequent analyses in the other six regions in Utah are similar to that for the southeast, the BLM recommendation for wilderness would be 5.6 million acres, the same as America's Redrock Wilderness Act. Such a drastic change of thinking illustrates just how far the BLM had come since it first set out in 1976 to inventory its lands for wilderness. 
Table VI. BLM WILDERNESS STATISTICS

\begin{tabular}{lcccccc}
\hline State & $\begin{array}{c}\text { Size } \\
\text { (million acres) }\end{array}$ & $\begin{array}{c}\text { BLM Land } \\
\text { (million acres) }\end{array}$ & $\begin{array}{c}\text { BLM Wilderness } \\
\text { Areas (1) }\end{array}$ & $\begin{array}{c}\text { BLM Wilderness } \\
\text { (acres) }\end{array}$ & $\begin{array}{c}\text { BLM Wilderness } \\
\text { Study Areas (1) }\end{array}$ & $\begin{array}{c}\text { BLM Wildemess } \\
\text { Study Areas (acres) }\end{array}$ \\
\hline Alaska & 393.7 & 6.5 & 0 & 0 & 1 & 784,238 \\
Arizona & 73.0 & 14.2 & 47 & $1,396,406$ & 2 & 63,930 \\
California & 104.8 & 14.7 & 76 & $3,618,312$ & 79 & 976,145 \\
Colorado & 66.6 & 8.3 & 4 & 139,524 & 55 & 623,021 \\
Idaho & 53.5 & 11.8 & 1 & 802 & 66 & $1,491,446$ \\
Montana & 94.1 & 8.0 & 1 & 6,000 & 40 & 452,563 \\
Nevada & 70.8 & 48 & 24 & 995,533 & 83 & $3,819,727$ \\
New Mexico & 79.1 & 12.8 & 3 & 139,281 & 55 & 958,964 \\
Oregon & 63.0 & 16.2 & 4 & 186,723 & 89 & $2,740,019$ \\
Utah & 54.3 & 22.9 & 3 & 27,720 & 95 & $3,260,130$ \\
Washington & 45.6 & 0.4 & 1 & 7,140 & 1 & 5,518 \\
Wyoming & 62.6 & 18 & 0 & 0 & 42 & 577,504 \\
Totals & $-\ldots$ & 161 & $6,512,227$ & 585 & $16,328,238$ \\
\hline
\end{tabular}

Source: BLM Public Land Statistics 2002 (as of September 30, 2002). Statistics for Nevada have been updated to reflect passage of the Nevada Clark County Conservation of Public Lands and Natural Resources Act of 2002 (Wildemess Information Network 2004 and BLM Nevada 2004).

(1) The sum of numbers of wilderness areas for individual states does not equal the total because some wildemess areas and wilderness study areas cross state lines. 


\section{PERSPECTIVES FOR A CRITIQUE}

The historical narrative of the two inventories explores the influence of national, regional, and local forces. Two other perspectives provide further interpretation of the wilderness debate. The first of these perspectives incorporates the

spatial analytical techniques of geographical information systems to provide a relatively impartial view of the landscape. The characteristics that are used to define wilderness, such as naturalness remoteness, and solitude, are combined with estimates of the impact of multiple uses of the land. The resulting spatial pattern is a continuum showing how wildness varies across the landscape. The second perspective is that of the subjective views of the participants in the debate. $A$ textual analysis of the statements of both county residents as well as the Southern Utah Wilderness Alliance explores personal meanings of both wilderness in general and wilderness designation. These ideas influence how people choose to interact with each other, the federal government, and the environment itself.

\section{The View from a Distance}

Reading environmental impact statements can often seem like viewing a large painting from very close. Context and meaning are often lost in the study of detail. The analyses performed by the BLM subsequent to their original inventory (1990b) and re-inventory (2002) contain a large amount of detailed information about each potential wilderness area presented in a relatively objective manner. Assessment of the 
naturalness of areas and the potential for solitude and uncontained recreation are presented alongside evaluations of mineral resource availability, grazing activity, and socioeconomic factors. However, the logic supporting a decision for or against wilderness is hard to find.

Notably absent is a sense of how these areas compare to one another. Even the BLM's original inventory assessments $(1979 \mathrm{a}, \mathrm{b})$ present little information on the ways in which these wilderness study areas might differ from those that were not selected for study. Simply making a binary division of wilderness/nonwilderness is not very discriminating. Nash (1982) describes wilderness as a spectrum or scale of conditions ranging from purely wild to purely civilized. Wilderness and civilization combine to give an area its character. Within this variation in intensity of civilization, wilderness is the area least under human control. An analysis that acknowledges this shading and blending, this continuum of wildness, and represents it spatially can be of great value.

To create a continuum of wildness for San Juan County, I used spatial data to represent characteristics of the landscape that define wilderness: naturalness, remoteness, and solitude. I also assessed multiple-use characteristics such as mining, energy resource development, grazing, tourism, and off-highway vehicle use. This analysis acknowledges existing and even potential human impacts, and does not account for how policy changes, such as toad closures and development restrictions, might change the character of the landscape. My intent is to provide a different and 
nominally objective perspective, not to determine which lands are appropriate for wilderness designation.

I used ArcInfo GIS software for this analysis, and the appendix provides the detailed methodology. For each landscape attribute, raster surfaces were created and classified with each cell assigned a value on a scale of $1-10$. The cell size used for the analysis was 90 meters. When the surfaces are combined, the result shows how wildness varies across the landscape. Aplet, et al. (2000) have used a similar approach to develop a measure of wildness at a scale encompassing the entire United States using GIS analysis. They used population data as a surrogate for solitude, roads data as a surrogate for remoteness, and land use/land cover data plus patch metrics as a surrogate for naturalness. Kliskey (1994) used a related approach to map what he called wilderness perception. This concept is generally taken to be a function of opportunities for solitude and the various human impacts on the landscape.

The first landscape measures I developed take into account the characteristics of the landscape as described by the Wilderness Act. Wilderness is land that is both natural and free of human influence and can be represented by attributes representing solitude, remoteness, and naturalness. As a surrogate for solitude, I used population density calculated from census data for fourteen towns in the county. Distance from roads was used as a surrogate for remoteness. Since there are only about a dozen paved roads in the entire county outside of the towns, I used datasets showing all three major types of roads: paved, gravel, and dirt. Each was classified separately since the amount of traffic and associated levels of impact will vary with each type. All roads 
mapped by San Juan County were included in the analysis, even though some of them may rightly be considered ways and not roads.

Developing a surrogate measure for naturalness was much more difficult. Land use/land cover maps show that only 2.5 percent of the land in the county is urban or devoted to agriculture. Even though most of the land may be considered natural at the scale of these land use/land cover maps, its wildemess characteristics are often disputed at a smaller scale. The landscape is also dissected by many canyons, and the result is often a lack of large tracts of unfragmented landscape, both natural or not. This makes relying on patch metrics, such as size and shape, to determine the naturalness of a landscape problematic.

However, it is clear from the history of land use in the county, and my own fieldwork, that the relatively flat areas of mesatops and wide wash bottoms are far more likely to see the impacts of humans than the less accessible canyons. This observation, of course, does not consider remnants of pre-historic cultures to be detrimental to wilderness characteristics. In even the most remote locations, mesatops are marked by occasional human impacts thanks to the longstanding grazing tradition. On these mesatops, both desert shrub and grassland areas are more.likely to be used for grazing than pinyon and juniper woodlands. Another reason to distinguish between canyons and mesas is that the BLM considers topographic and vegetative screening in its analysis of wilderness chatacteristics to determine opportunities for solitude. However questionable this may be as a measure of solitude, canyons and 
expanses of woodlands are considered better places to be alone than open shrub and grassland.

Taling these various factors into account, I used slope calculations derived from digital elevation models to distinguish between canyons and mesas. These slope measurements were combined with a modified classification of land use/land cover data that accounted for the higher likelihood of human impacts to desert shrub and grassland than woodlands or barren land. This hybrid measure was used as a surrogate for the likely naturalness of the landscape. To be sure, other measures would be helpful in establishing naturalness. Critical habitat for protection of biodiversity, locations of invasive species, and an assessment of the condition of rangeland would all be helpful. However, such data were not available for use in this analysis.

Figure 16 shows the distribution of each of the landscape measures that define wilderness characteristics. I combined all three of these landscape measures, with each weighted equally, to produce a map of the wilderness characteristics of all lands in the county, presented as a range from most to least wild. Figure 17 displays this continuum of wilderness characteristics.

To determine whether an area should be recommended for wilderness, the BLM typically evaluates a variety of possible uses. In a like manner, I developed a series of landscape measures to estimate the impact of different uses. For San Juan County, the major considerations are tourism, off-highway vehicle use, mining, energy development, and grazing. 


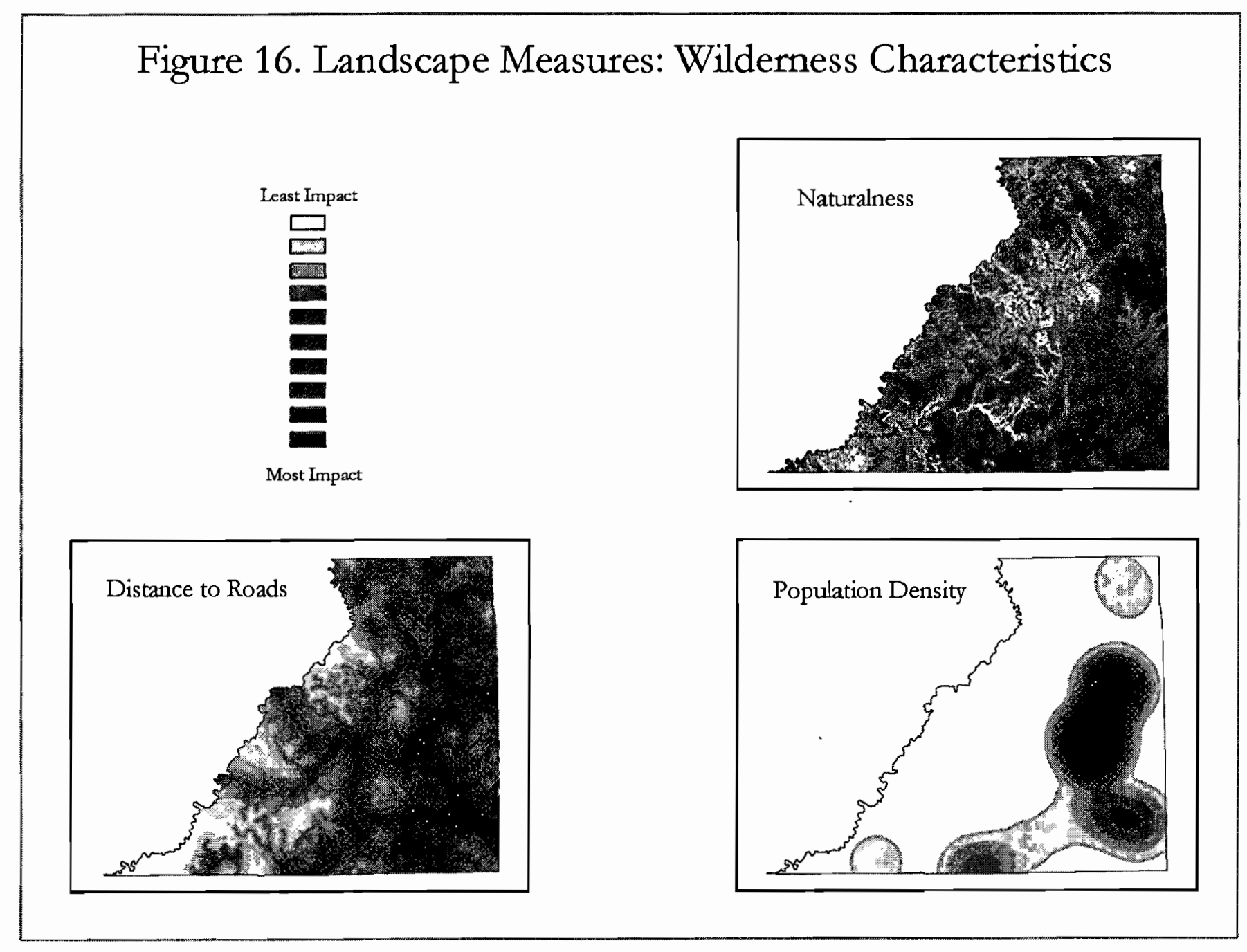




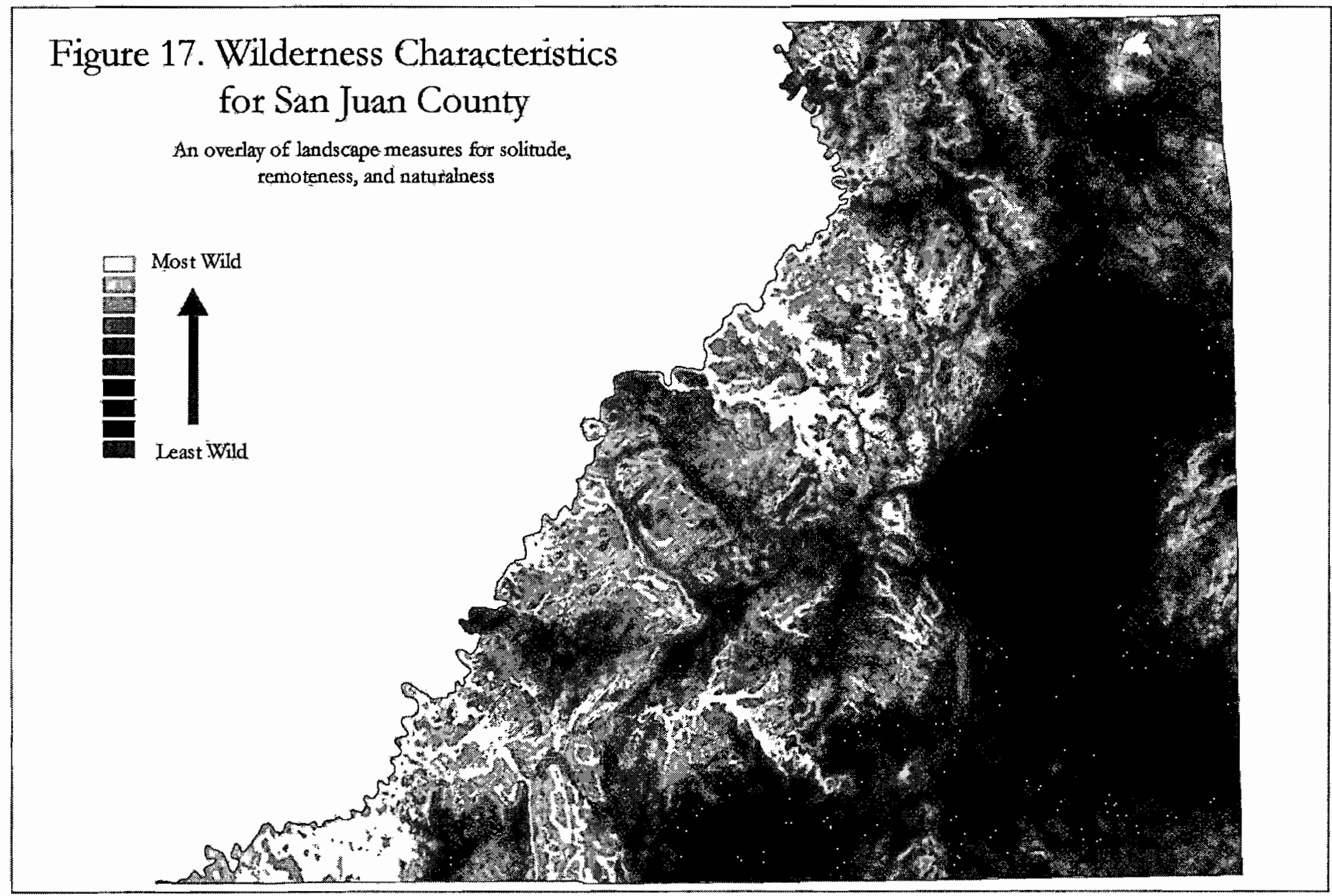


To measure the impact of tourism, I used visitor counts for the national parks and monuments, state and tribal parks, Lake Powell, and Manti-LaSal National Forest. BLM visitation numbers were not included. The BLM keeps few visitor statistics and the numbers are insignificant compared to any of the other agency's sites in the county. Off-highway vehicle use is more difficult to evaluate. A county $\mathrm{OHV}$ event took place in September 2003, and I used a map of these routes to determine the areas most likely to be affected by OHVs. Datasets available from Utah state agencies provided estimates of the impact of current and past mining activity and energy resource development. Current and potential extraction activity as well as the visual impact of abandoned mines could be accounted for and rated based on the size of the deposit. Data for energy resources were somewhat different, and I used a rating system that accounted for the likelihood of extraction as well as the size of the deposit. Once again, accounting for the impacts of cattle grazing presented a problem. First, wilderness and grazing are not incompatible in the legal sense. Second, most of BLM land in the county is allotted for grazing and the stocking rates for these allotments are similar. Although structures associated with grazing, such as fences, stockponds, corrals and the like are widespread, they are generally considered unnoticeable. Such areas are only excluded from wilderness consideration by the BLM when there is a cumulative effect. An exception is land that has been chained or received other vegetative treatment, but datasets were not available delimiting these areas. As a result, I did not include grazing in the measures of multiple use. Indirectly, 
the measure of naturalness described above accounted for the effects of grazing. Figure 18 shows the distribution of the four landscape measures of multiple use.

Finally, I combined all seven landscape measures to produce a map of the wildness of all lands in the county. I weighted the attributes affecting wilderness characteristics more heavily than the multiple use attributes. This wildness map is shown in Figure 19. The lands in the county vary by degree of wildness, a product of inherent naturalness and the influences of human impacts.

The overall pattern that emerges from the wildness map reflects much that could be expected from reading about and observing land use in the county. The areas of greatest human impact are located along the Highway 191 corridor. Agricultural lands are found almost exclusively on the great sagebrush plain. Intensive oil and gas developments are located in the Blanding Basin and Lisbon Valley. The national forests, especially the Abajo Mountains in close proximity to the towns of Monticello and Blanding, are more heavily used than BLM lands. Some of the wildest land can be found on the Navajo Indian Reservation, and most of the land in the western half of the county is quite wild with a few exceptions. Those exceptions are the uranium mining and popular off-highway vehicle area south of White Canyon, the lands within and surrounding the basin that contains Canyonlands National Park, and some development near Lake Powell. The similarity of the spatial patterns of Figure 17 and 19 would indicate that the likelihood for multiple-use activities to be restricted by wilderness designation is small. 


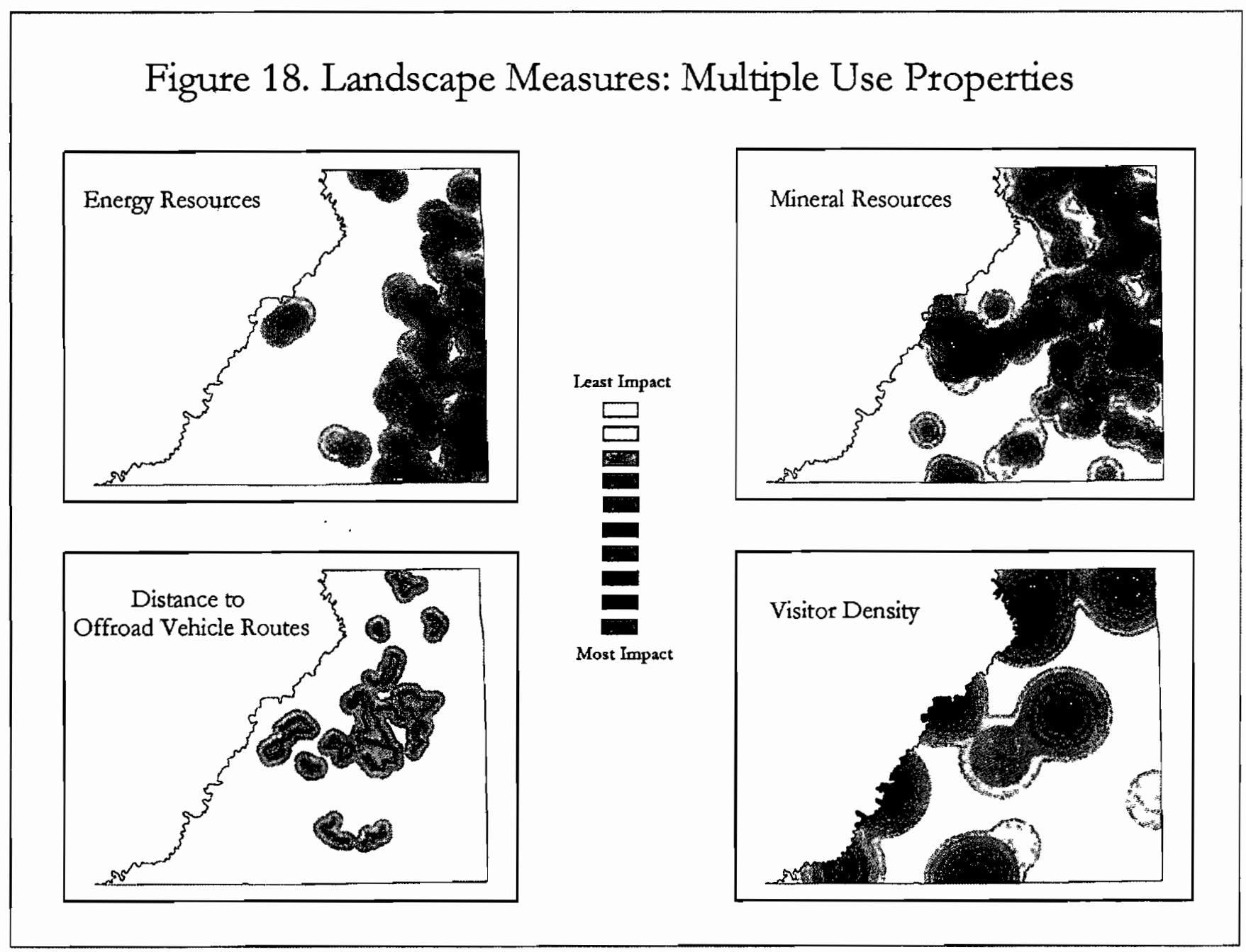




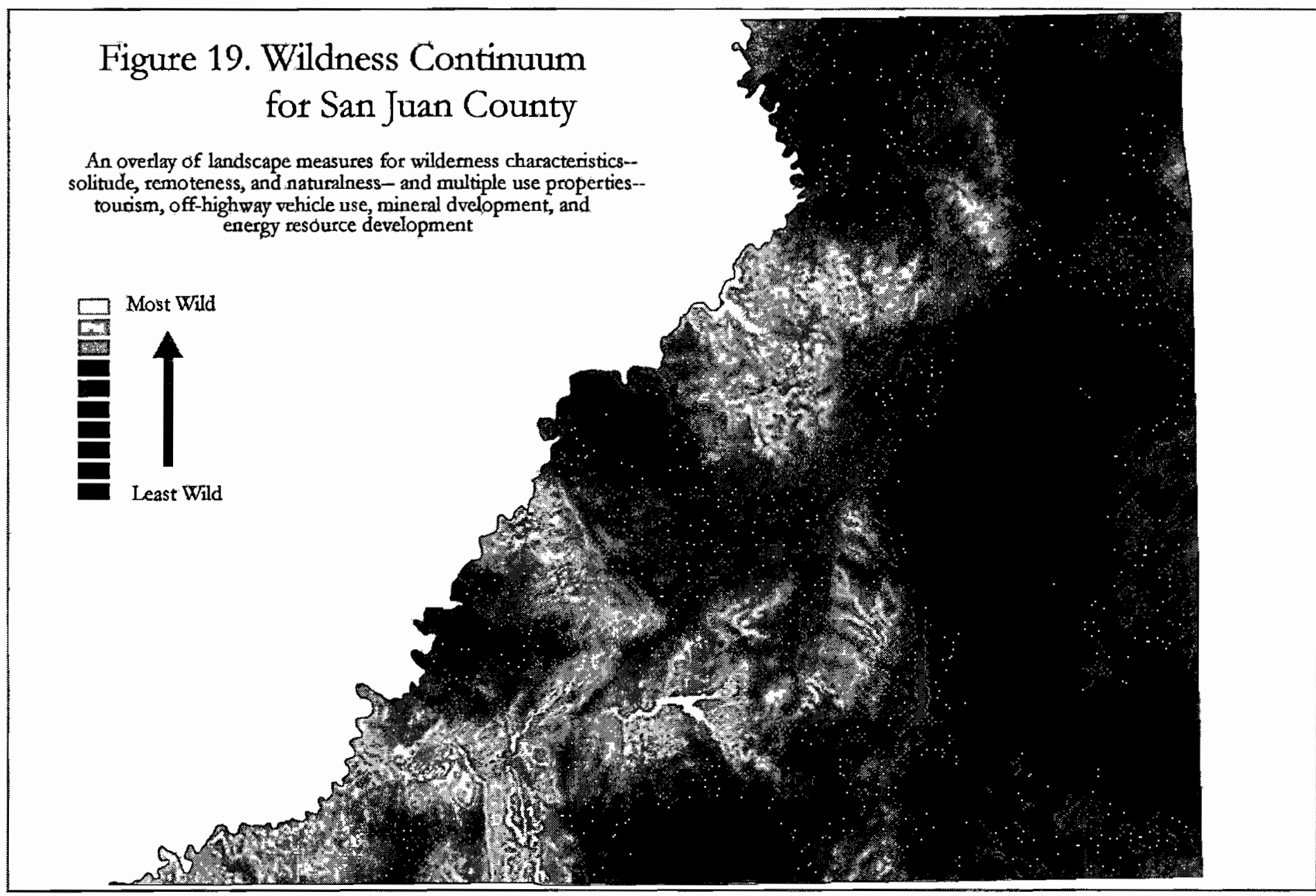


Not only does the wildness map highlight the best potential wilderness areas, but when overlayed with various wilderness proposals, the map can identify areas of controversy or agreement. Wilderness study areas, re-inventory study units, and citizens' inventory units from 1999 are outlined for comparison in Figure 20. The complete citizens' inventory includes all WSAs and RSUs, but only the additional recommended areas are shown. BLM wilderness study areas are located at the most wild end of the wilderness spectrum. With few exceptions, areas of potential economic development lie far removed from these potential wilderness areas. However, as more land is incorporated as proposed wilderness, such as the re-inventory study units and additional citizens' inventory units, these additions are closer to roads and population centers and include areas with a history of heavy visitation and off-highway vehicle use. Many of the canyons in the region are already included in the WSAs, so these additional lands often are the more easily accessible flatlands of the mesatops, expanses of pinyon and juniper woodlands or sagebrush parks. The result is a kind of inverted nomenclature for the wilderness debate. Environmental groups are not wilderness purists, but are willing to think of land that falls more towards the middle of the spectrum as wilderness. In contrast, the county and Utah congressional delegation are the wilderness purists, recognizing as wilderness only those lands towards the end of the wildness spectrum.

Figure 21 displays the differences between several of the proposals in another way. When all the land in the county is categorized into quantiles using the wildness map, $60 \%$ of the WSAs, $5 \%$ of the RSUs and none of the additional citizens' 
Figure 20. Wildness Continuum and Wilderness Proposals for San Juan County

$\square$ BLM Wildemess Study Areas

BLM Re-inventory Study Units

Additional Citizen's Re-inventory Units
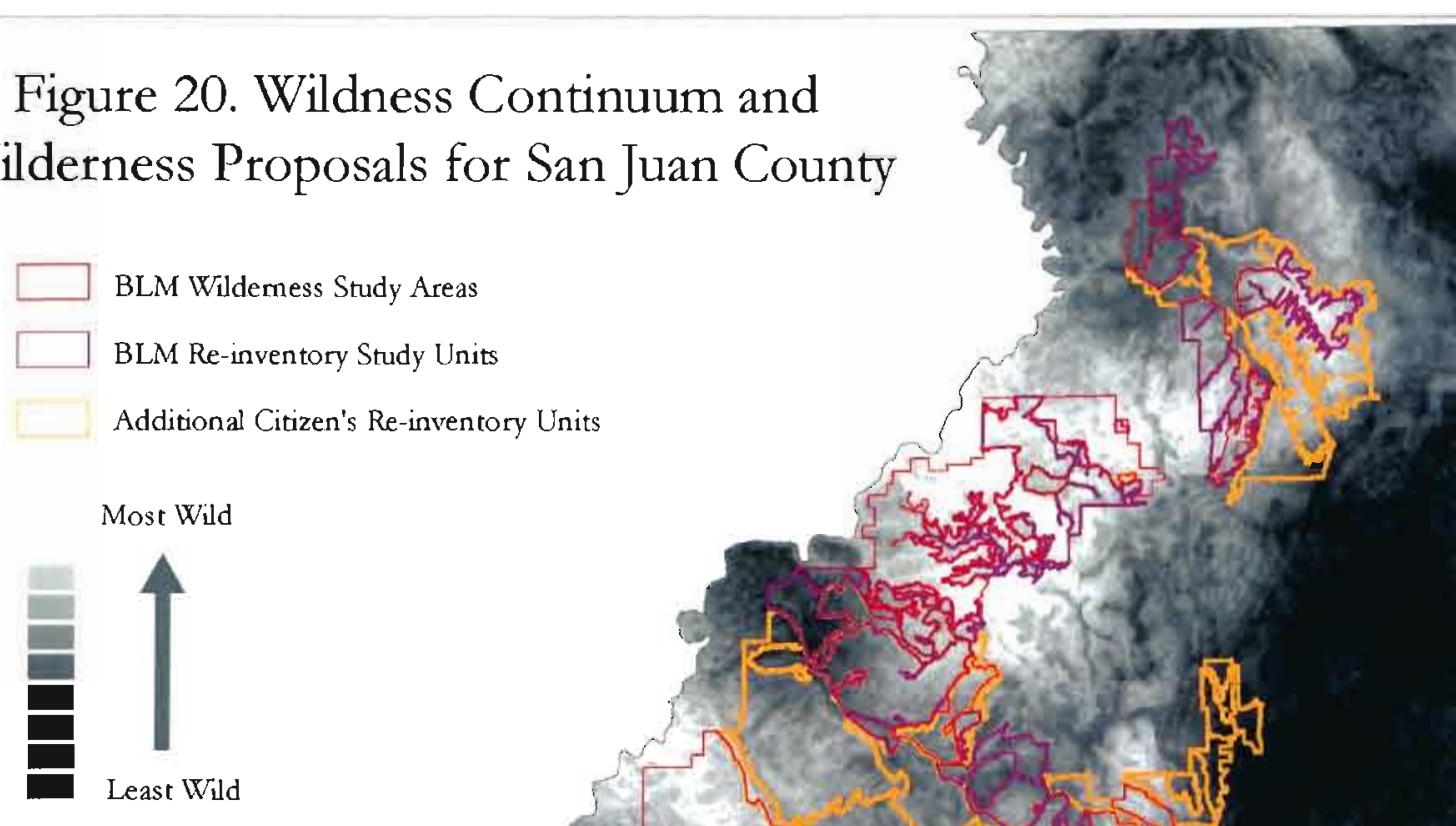

$-x^{2}-2$

(2) $5 b^{2}$

Wild

it

Least Wuld

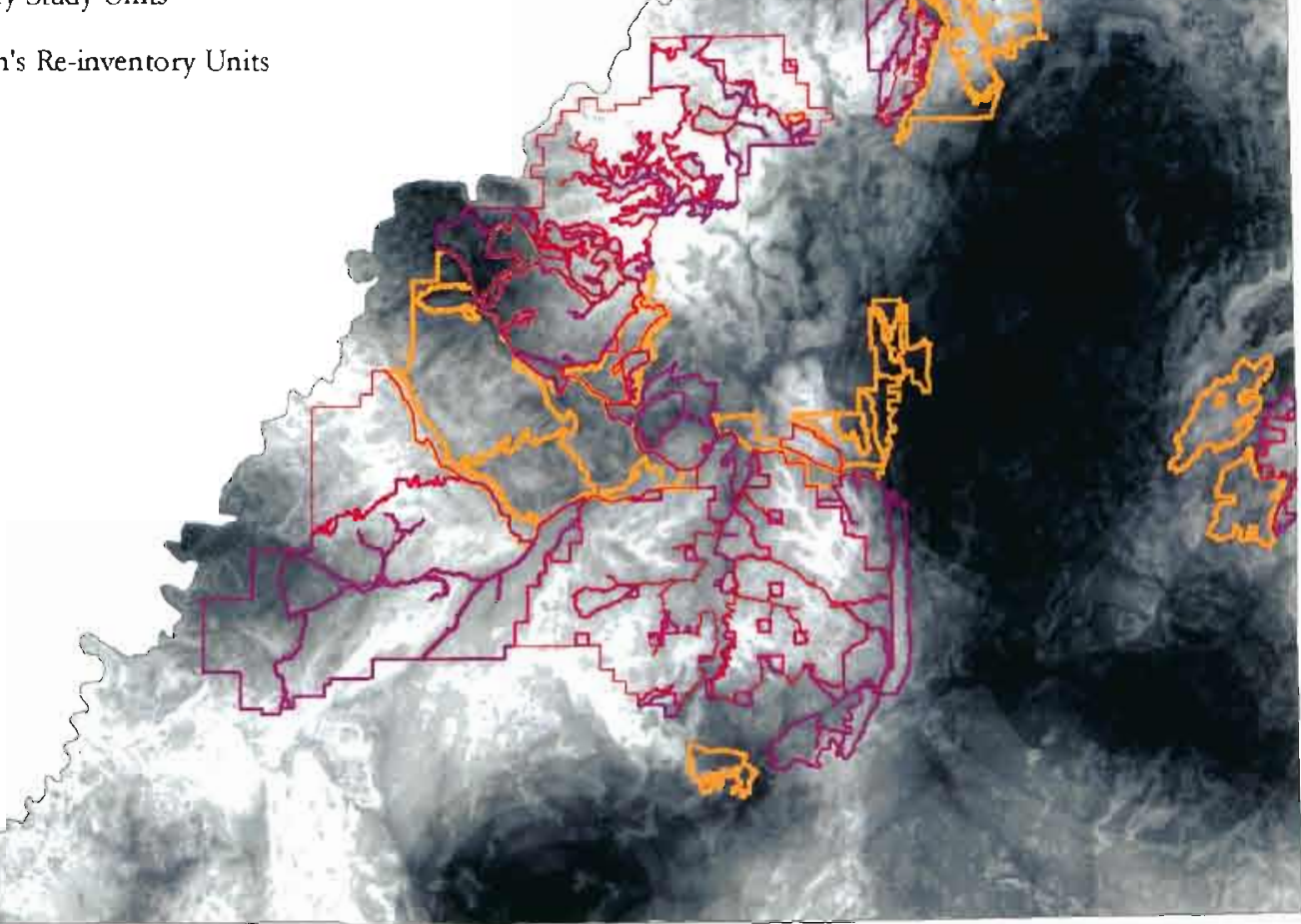




\title{
Figure 21. Distribution of Inventory Units in the Wildness Continuum
}

\author{
4th Quantile/Least Wild \\ 3rd Quantile \\ 图2nd Quantile \\ $\square_{1 \text { st Quantile/Most Wild }}$
}

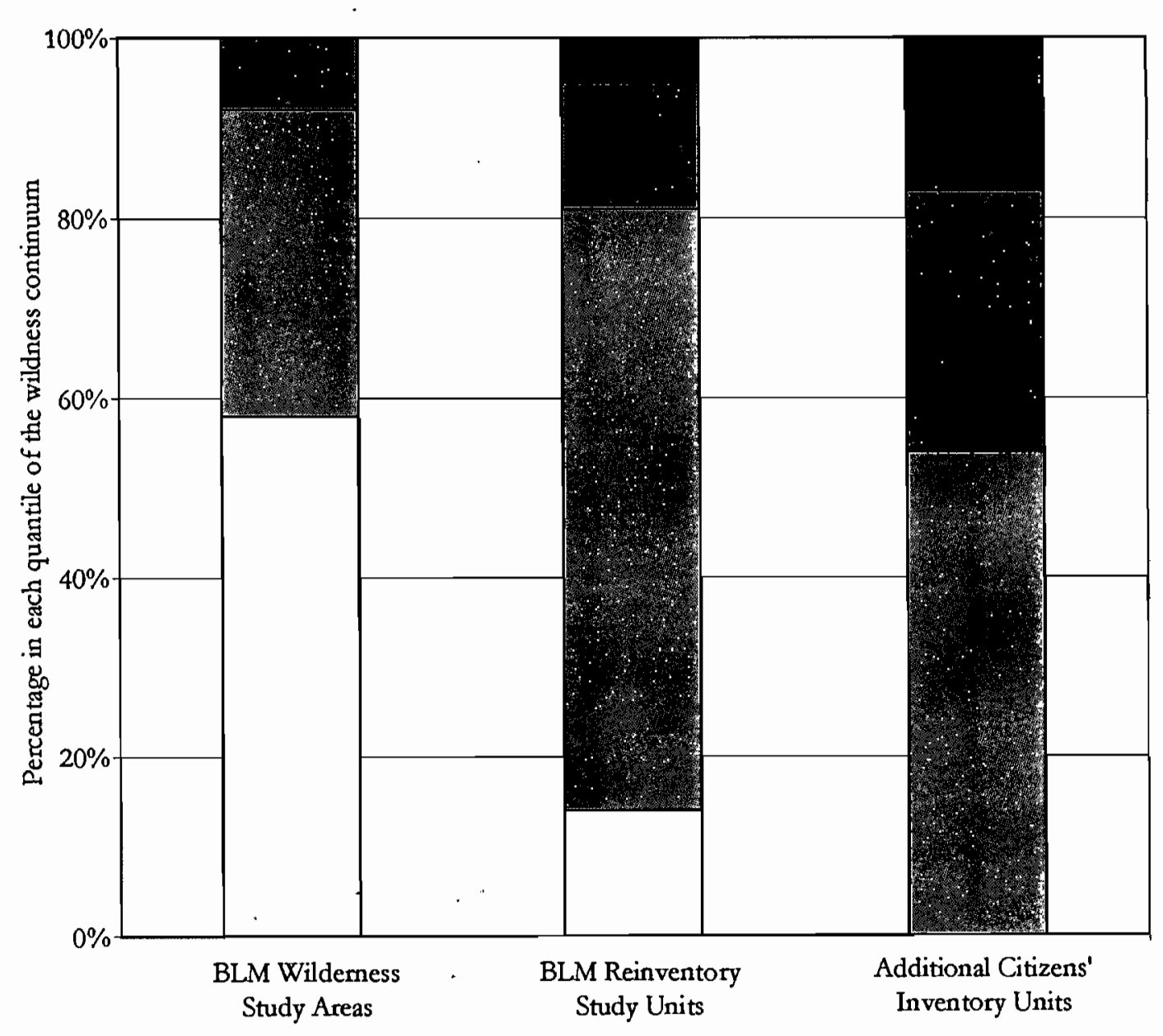


inventory units are found on the most wild land. Looked at from the other end of the spectrum, only $8 \%$ of the WSAs and $15 \%$ of the RSUs are on the less wild half of the spectrum, but more than $50 \%$ of the additional citizens' inventory units meet that criterion. In general, the BLM re-inventory study units, essentially the same lands in the Red Rocks Wilderness Act in 1995 (minus the WSAs), are less wild than the wilderness study units. The additional lands from the citizens' inventory are less wild still.

Of the WSAs, the only unit that falls on the less wild half of the spectrum is Indian Creek. In comparison, the four RSUs on lands on the less wild side of thespectrum are Indian Creek and White Canyon units of Cheesebox Canyon, Sheep Canyon, and Fortknocker Canyon. The least wild citizens' inventory units include Indian Creek, several bordering Manti-LaSal National Forest and Comb Ridge, several in the White Canyon region, and Tin Cup Mesa near Squaw and Papoose Canyons. The wildness map in essence provides a visual summaty of the elements of the conflict. Specific comments and evaluations of wilderness potential can be evaluated by comparison with the spatial patterns. It is fair to say that the BLM has been quite reasonable in its wilderness evaluations, at least when the re-inventory lands are acknowledged. Clearly, many of the wildest lands in the county, those substantially free of impacts, coincide with potential recommended wilderness areas. In contrast, one of the most vehemently contested areas, Cheesebox Canyon, is shown as one of the least wild of the WSAs. It is not surprising that this area is always on the borderline of recommendation as wilderness by the BLM. On the other hand, another hotly 
contested area, Hart's Point, appears to be quite wild, and one might question the exclusion of most of this unit in the re-inventory analysis.

Questions can be easily raised about the county's wilderness evaluations. Within the large expanse of isolated and wild lands of Dark Canyon, a few small impacted patches can be rightly seen as insubstantial. The tactic used by antiwilderness groups, and the BLM in its initial inventory, to exclude large areas because of a few small impacts is exposed as misrepresenting conditions on the ground. Inconsistency is another trademark of the county's assessment. Some lands are recognized as wilderness while others of similar character are not. In this light, their so-called objective analysis disguises a hidden agenda. It is worth noting that this evaluation is in one respect biased in favor of the county's evaluation. It takes for granted the permanence of dirt roads claimed by the county, even if many of those roads are virtually nonexistent.

In contrast to the county's evaluations, the citizens' re-inventory includes certain areas on the less wild end of the spectrum. The explanation for the inclusion of these areas lies outside the factors used to create this map. SUWA has acknowledged that all areas it recommends for wilderness designation do not have the same wildness qualities. A standard of what might appear wild to the hypothetical typical visitor unfamiliar with the landscape is used (personal communication with SUWA 2002). The recommendation of some areas as wilderness, such as the Red Rock Plateau between Mancos Mesa and White Canyon, is not based on current use patterns but predicated on the closing of roads and banning of certain activities. Most units 
bordering Manti-LaSal National Forest make sense only in conjunction with the possibility of wilderness designation across agency boundaries. Small islands of relative wildness that exist amidst a sea of developed land, such as Squaw and Papoose and Cross Canyons, meet the letter but not the spirit of the Wilderness Act. These lands are of a much different nature from those in the west, and a different kind of protection may be more appropriate than wilderness designation.

At the scale of small wilderness units, those less than 10,000 acres, the wildness map is not always consistent with consensus wilderness recommendations. Although it even appears in the county's proposal, Indian Creek WSA is shown to be a likely controversial area, the result of the heavy use of lands that surround it. This illustrates a general problem with small wilderness units, and that is the danger of encroaching impact. However, the intent of this analysis is not to note every on-theground intrusion or impact, but to describe the general character of the land, in the same way that general trends and ratings are used for evaluation in environmental impact statements.

Certainly the unit of a county boundary is an arbitrary choice to evaluate landscape characteristics. Such boundaries often bear little relationship to existing landforms and biotic communities. How does the pattern of wildness change just beyond that boundary? In general, it changes very little. To the south, the Navajo Indian Reservation extends far into Arizona, and the pattern would be expected to remain the same, isolated communities amongst mostly wild desert lands. To the east, the Great Sage Plain and Blanding Basin extend into Colorado, changing little in 
character until reaching the town of Cortez forty miles from the border. Although the wilderness study areas of Squaw and Papoose and Cross Canyons are small extensions of the larger Canyons of the Ancients National Monument, those canyons are still an island in a sea of agticulture and oil and gas development. To the west, the border is the Colorado River and Lake Powell, and undeveloped lands extend into and beyond the Henry Mountains and the Kaiparowits Plateau. To the north lies Moab, a town not much larger than Blanding but with decidedly more tourism, and this could affect the look of the wildness map.

These measures of landscape characteristics provide a base map with which the rhetoric of competing interests can be juxtaposed and compared. In the battle of ideas, these landscape measures are a decidedly less subjective counterpoint.

\section{The View from Somewhere}

San Juan County. In a San Juan Record article about a local wilderness meeting, the reporter quoted some as saying " witbout wilderness designation, future generations will lose a valuable heritage" while others said "with wilderness designation, future generations will lose a valuable heritage" (San Juan Record 1995a). So goes the discussion about wilderness designation in southern Utah.

I performed a content analysis of editorial comments written about wilderness issues in the San Juan Record, a weekly newspaper published in Monticello. This paper advertises that wilderness issues are one of the five major topics the paper covers in depth. I reviewed letters from the time period of 1995 through 2002, which 
incorporated commentary from the beginning of the county proposals for wilderness through the BLM wilderness re-inventory process. Local citizens provide most of the editorial content of the paper with occasional pieces written by state officials, SUWA representatives, and visitors to the county. Regulat contributors include county commissionets, former BLM employees, and members of the Southeast Utah Land Users (SULU). The polar nature of the wilderness debate makes it easy to categorize county commentary into pro- and anti-wilderness stances. Of the 145 pieces reviewed, $101($ or $70 \%)$ were against wilderness designation, $26(18 \%)$ supported wilderness designation, and $18(12 \%)$ presented a balanced argument recognizing the validity of both sides of the issue. Only the latter group used words and phrases such as "compromise and cooperation," "working together," "respectfully allowing debate," or "learning to accept each other in spite of differences."

Compared to surveys where both the questions and answers are provided, personal letters emphasize and account for what people actually write (Proctor 1998). In the forum of the local newspaper, the letters express opinions that are both rational arguments and unedited emotions. They are also not intended to be coercive, as public comment on a particular government action might be. Of course, these opinion pieces do not necessarily represent the public at large as a scientific survey can. However, the distribution of the letters for and against wilderness is similar to a reported survey conducted by Utah State University, which placed opposition to wilderness in San Juan County at 77 percent (San Juan Record 1999). As Goodman and McCool (1999) 
have noted, there are countless surveys of public opinion on wilderness issues in Utah, and little agreement on what they conclude.

To gain a better understanding of the anti-wilderness ideology of the county residents, I categorized the types of arguments expressed. The three types of justification, or anti-wilderness themes, are environmental, economic, and social. The latter two predominate. Five major categories of discourse could be identified: against environmentalists, against federal government control, for multiple use of public lands, for unrestricted access to public lands, and for local control over public lands. A less common but more nuanced type of argument against wilderness designation claimed that the land is de facto wilderness and protected by other laws. Table VII summarizes these anti-wilderness arguments.

This discourse also helps to establish the basic frames that define the wilderness conflict. Gray (2003) states that frames serve a number of purposes, such as defining the issue at stake, justifying stances on the issue, and shaping the actions taken by participants. The key frames common to many environmental disputes are identity frames, characterization frames, and conflict management frames. Social control and power frames are important as well.

Forty percent of the articles expressed what could be called an antienvironmentalist stance. Disparaging words are used to characterize environmentalists: elite preservationists, leisure-class elites, Mother- Earth types, zealots, ecoterrorists, econuts, selfish hedonists. These descriptions create a framework that separates this suspect segment of society from the local people. Environmentalists do not represent 
TABLE VII. ARGUMENTS AGAINST WILDERNESS DESIGNATION FROM THE SAN JUAN RECORD

\begin{tabular}{|c|c|c|}
\hline Theme & Type of Argument & $\begin{array}{c}\text { Percentage of } \\
\text { Reviewed Letters }\end{array}$ \\
\hline \multirow[t]{4}{*}{ Social } & Anti-environmentalists & 40 \\
\hline & Anti- federal government & 20 \\
\hline & Rights to access for recreation & 19 \\
\hline & $\begin{array}{l}\text { Fairness to local residents } \\
\text {-Native Americans } \\
\text {-Others }\end{array}$ & $\begin{array}{c}3 \\
14\end{array}$ \\
\hline & Multiple Ise/Customand Ise & \\
\hline \multirow[t]{2}{*}{ Economic } & Multiple Use/Customary Use & 20 \\
\hline & Anti- tourism & 4 \\
\hline \multirow[t]{2}{*}{ Environmental } & $\begin{array}{l}\text { Insignificant impacts from } \\
\text { development }\end{array}$ & 5 \\
\hline & $\begin{array}{l}\text { Protection afforded by other } \\
\text { environmental laws }\end{array}$ & 4 \\
\hline
\end{tabular}

Note: Percentages do not sum to 100 percent because some letters developed more than one major type of argument. 
the majority, but have still managed to anoint themselves as experts. They wish to exclude everyone but themselves from public lands.

"The question that presents itself is why should these self-appointed selfserving organizations pursuing an agenda of hatred and intolerance be given front page news coverage every time they unleash a new attack on their victims? I do not know the answer, but I know what the result will be if this trend continues unchecked: The beautiful places of our public lands will be forever locked away beyond the reach of most of our people." (Rainier Huck, President of the Utah Shared Access Alliance, 12/22/1999)

To achieve their goals, environmentalists spew propaganda, twist facts, and

deceive politicians.

"You cannot even begin to imagine the frustration, pain, and tears that I, my family, and many others, experience when misinformed politicians, uneducated environmentalists and the Godless forces of environmental extremists combine to lock up the land in the name of wilderness protection." Joe Lyman, 6/2/1999)

They are also heartless when it comes to rural communities. Almost half of these articles specifically single out SUWA as the greatest of the environmentalist offenders. "They (SUWA) could care less about rural Utah communities; and they would not mind at all if such communities disappeared so that wilderness could be expanded" claims Robert Anderson (2/26/2001).

Occasionally, there are complaints about the presence of related but slightly less-reviled (eco)tourists overrunning the land. Juxtaposed to the backpacker and mountain biker tourist of neighboring Grand County, San Juan County has embraced off-highway vehicle users as their own. Those using motorized access to visit public lands are seen as fitting in with the majority of county residents. The vehicles allow for a more democratic access rather than limiting it to the physically-fit elitist. 
"Their (SUWA, Sierra Club, etc.) insistence that hiking without use of motorized vehicles is the only way to enjoy nature borders on religion or mysticism. And no one's religious or quasireligious views are entitled to be enforced by government power." (Jim Bourne, SULU, 4/19/2000)

Clearly, as evidenced by these descriptions, environmentalists are an exceptionally unattractive bunch. SULU draws the unusual analogy that "The Taliban use whips, sticks, rifle butts, even death to enforce their will or beliefs upon people. The 'environmentalists' use the courts. Is there a difference? Both feel their way is the only way" $(1 / 2 / 2002)$.

Twenty percent of the articles take an anti-government approach. However, this argument does not apply to all government entities, but works on a sliding scale of decreasing hostility from federal to state that notably excludes the local county commissioners. These arguments are about social control, and often overlap with the discussion about how much say locals should have in public land management.

"It was absurd and tyrannical 200 years ago for those across the ocean to tell the colonists how to live and what they could and couldn't do. It is equally absurd and tyrannical for the voices of those who live thousands of miles away from the land in question to make this decision as opposed to the entitled, weighted opinion of those who live locally." (Lynda Boyle, 6/23/1999)

Much of the invective is aimed at the actions of Bruce Babbitt and Bill Clinton specifically.

"The same arrogance, secrecy, dishonesty, willingness to ignore the fundamental requirements of a democratic government to deal faitly with its citizens, and the clear disdain for involving the public and state and local officials in the decision process which characterized the recent designation of a national monument in Utah, is also reflected in the way the re-inventory has been conducted." (Unnamed Utah Association of Counties spokesman, 10/16/1996)

It is often their intermediary, the BLM, that takes the abuse. 
"Don't you see what's happening? They aren't leasing oil and gas anymore, the grazing is being shut down. This is the idea- they are creating wildernesswhether we like it or not." (Ed Scherick, former BLM field office manager now county planner, 8/19/1998)

On the other hand, the local BLM field office receives praise when it approves mining or $\mathrm{OHV}$ activities. Some are even nostalgic for the BLM of the past, ignoring similar animosity that existed then, just a short twenty years ago. "Mr. Turri was in land management with the BLM in the "good old days" when they remembered what multiple use was all about" remembers John Black (3/21/2001). As a result, the BLM, although generally an adversary, is not clearly characterized in the eyes of the local residents.

Multiple use policy and economics arguments comprise twenty percent of the arguments. "This is a natural resource county and any kind of energy and power development is good for San Juan County" states County Commissioner Ty Lewis about the Bush energy plan (5/2/2001). Robert Turri, a retired BLM field office manager, says "So much land managed under a single use would not be healthy for the western states. As we face proposed national park expansions, vast wilderness proposals, and more national monuments, we fight back as best we can ..." $(7 / 14 / 1999)$. There is a strong impression that federal land is needed as a natural resource, and wilderness protection will result in a loss of economic opportunity.

Again, this argument is also framed as one of social control. County Commissioner Bill Redd comments about oil/gas leasing, 
"While southern Utah has more National Parks, monuments, recreation areas and things of that nature than any other area in the United States and we have the lowest per capita income. San Juan County is the fourteenth most povertystricken county in the United States. We should have a right to make money off of the natural resources in the area. All we are asking for is the same rights as rural citizens in other states have." (4/29/1998).

Sometimes the argument is about customary use, and tourism is mentioned as a force

that is changing the face of county life.

"It is clear to me that the greatest threat to the remarkable western lands is not from ranching or mining, but from visitation; an evergrowing horde of weekend warriors who are recreating this land to death... The way to have healthy and stable economies is to have a balance between tourism, mining, and agriculture." (Bill Boyle, San Juan Record editor, 6/3/1998)

The legal right of access to public lands is the main concern of nineteen

percent of the letter writers. The word freedom often appears, and is the concept most important for the government to uphold.

"I read quotes that the majority of people in San Juan hate wilderness when the opposite is true. Living in a wilderness allows us clean air, water and other things that urban residents do not enjoy. I suppose you could say we have a common sense about what wilderness really is, because we live here and know that southeastern Utah is very much a wilderness area. The issue is really about freedom. Freedom to be able to have an economy that will sustain future generations. Freedom to be able to go on public lands without permits when we live only a few minutes away from these lands we love. Freedom to continue as residents in a wilderness that all of us know as our home." (Kelly Mike Green, 4/12/1995)

The federal government is also occasionally relied upon, through the Americans with

Disabilities Act, and with no hint of irony, to defend these freedoms.

"There are many senior citizens in this area who, due to a physical handicap, cannot visit and view these beautiful lands other than by motorized vehicle. Are they not important? Are not people as important as wildlife and vegetation? Should we lock up all these trails to be used by a privileged few who can hike?” (Jim Bourne, SULU, 9/29/99) 
The access argument is generally made in reference to motorized vehicle access, with many letters written by OHV groups. Rainier Huck, President of the Utah Shared Access Alliance, complains that "People on vehicles are being targeted because they are the last bastion standing in the way of massive Wilderness designations" $(12 / 22 / 1999)$.

An argument that locals care more about and deserve more from public lands is made in fourteen percent of the articles, although it is implicit in many of the antienvironmentalist tirades. This discourse establishes an identity frame for local residents, and separates them from outsiders, in particular those environmentalists. Residency in the county should confer certain rights to use federal land. Robert Turri, the retired BLM field office manager, questions how "Can those individuals (reference to a SUWA member and recent arrival) possibly care for our area more than those whose heritage is here, or those who have chosen this area to spend their lives?" (3/14/2001). "They (members of SULU) are decent longtime residents who feel the land belongs to them as it does to anyone else. Maybe more so since they settled and developed this area" states Jim Bourne, President of SULU, but himself only a five year resident of the county $(1 / 26 / 2000)$. The county even funded a recent rephotography project to illustrate how well locals take care of the land (San Juan Record 2000). Ironically, the before photos of barren overgrazed lands predate the Taylor Grazing Act. No mention is made of the government's role in managing the land in question. 
This group of locals is generally one that can trace their lineage to the Hole-inthe-Rock expedition. It is unclear how influential the Mormon religion is with respect to environmental views since god and religion are rarely mentioned in any letters. As Wallace Stegner (1990) has noted, the Mormon influence is a product of history as they are tied to this land by their persecution, settlement and church history. Utah was singularly theirs, and there was nowhere else to go. Unlike those in the rest of the west, they did not cut and run. This group identity creates a well-defined tight-knit community. It also crystallizes the opposition into a distinctively different culture. There is no sense or acceptance of a plurality of opinion and no local constituency for environmental protection that is accepted as part of the community. The insider and outsider have vastly different views of individual and societal purposes.

These local residents may work for the government or in services, but they are frontiersmen and ranchers at heart and cling to a mythic way of life in the face of the forces of change. The frontier attempts to live on in San Juan County.

"The ultimate irony is that many of these recreationists feel that a weekend or two playing in these canyons somehow gives them a pre-eminent say on how these lands should be protected ... We realize that tourism is needed and take great pride in the fact that people from throughout the world have come to appreciate the spectacular beauty of these lands. However, this country was built upon the principles of hard work- the cowboy ethic- and not upon the conspicuous consumption of a transient recreationalist." (Bill Boyle, San Juan Record editor, 6/3/98)

For the most part, the discussion of local rights to public lands ignores the majority of long term county residents who are of Native American descent. A few letters are written in which Native American treaty rights are mentioned as a reason not to designate certain areas in San Juan County as wilderness. 
"Wilderness will be violating the Native American Religious Freedom Act by curbing and denying access to the herbs and plants important to the Navajo healing rituals and sings. I ask, as many of my fellow Navajos are asking, please do not designate our Navajo Country as wilderness. You will negatively impact the practice of our tradition and culture and greatly hamper our healing rituals." (Tully Lameman 6/30/99)

Cedar Mesa and the lands contiguous with the Navajo Reservation on Nokai

Dome are specifically mentioned. These arguments are the same as those made in response to the original BLM inventory.

"These are areas from which the Navajos have harvested wood for hogan/corral construction and maintenance, worship/heating/cooking fuel; gathered material for handicrafts and herbs for medicinal purposes, maintained shrines of worship, and hunted big game to maintain their traditional lifestyle for centuries upon centuries." (Dick Neztsossie 6/30/99)

Place-specific attachments and the nature of the environment are rarely mentioned by the local writers. A study by Eisenhauer, et al. (2000) suggests that ties to public lands beyond its use value are important considerations for land management. The two most important reasons for special attachments are the environmental features and characteristics of a place, and associations of time spent there with family and friends. This study also found that recreational use rather than economic activity is associated with special places even in communities where there is much economic use of public lands. In the letters of opposition to wilderness, there is little mention of specific places. A mere ten percent made any'reference to the land in dispute, and then only in genetalities. Magnificence, grandeur, and beauty are characteristics of the landscape in general and the (unnamed) canyons in particular. Only the areas closest to the towns of Monticello and Blanding warrant specific mention: Arch Canyon, Comb Ridge, Cedar Mesa, and the Abajo Mountains. 
Several writers claim that the lands in question remain de facto wilderness with small or essentially no environmental impact. In reality, the best preservation is the nature of the land itself and its isolation.

"It is very obvious that hundreds of miles of canyons have protected themselves for over 100 years since the first modern-day settlers arrived. At the same time mineral, oil and grazing interests developed a meager foothold on some of the plateaus, rims, and flatlands to help sustain our ever-struggling economy. The scars of man on the landscape are of miniscule impact and, in fact, add to the outdoor experience because of the history they tell of the latest chapter of the human struggle which has existed in this wild, wonderful country for centuries." (Joe Lyman 6/2/99)

Others question the relevance of the Wilderness Act itself, claiming that it is a relict of the past, necessary at the time to protect the land from the consequences of human action. However, after the passage of NEPA, FLPMA, the Endangered Species Act, and other powerful federal legislation, it has been rendered obsolete.

A similar argument highlights the distinction between designated wilderness and the open space of the mythic frontier. Although it may seem a question of semantics, this argument is one that would resonate with those focused on the social construction of nature.

'Vast open wild lands are part of Utah's heritage, but severely restricted and congressionally designated political wilderness is not. If there were no difference, the wilderness debate would not be as divisive as it is ... You say that wilderness provides a "sense of beauty, revelation, spiritual renewal, and quiet recreation", as though these experiences are unavailable otherwise in the nearly 35 million acres of federal land in Utah. Our vast open wild lands, free of congressional designation as wilderness, provide the same values..." (Dale Black and Jim Slavens Mayors of Blanding and Monticello respectively 4/24/96)

Salt Lake City. The largest and certainly most prominent environmental group in the state of Utah is the Southern Utah Wilderness Alliance (SUWA) headquartered 
in Salt Lake City. SUWA is one of the four executive committee members of another prominent name in the Utah wilderness preservation movement, the Utah Wilderness Coalition (UWC). The UWC acts as an umbrella organization for 240 separate organizations within the environmental community interested in the preservation of wilderness in Utah. It was a pioneer in coordinating citizens' wilderness inventories of public lands and its work has been contagious, with citizens' inventories continuing to be conducted in all western states. However, SUWA is the dominant player in wilderness politics in the state with field offices in Moab and Monticello in southeastern Utah as well as Washington DC. Since SUWA has an active website and regular publications, exploring the organization's ideology is reasonably straightforward.

SUWA's mission is "the preservation of the outstanding wilderness at the heart of the Colorado Plateau, and the management of those lands in their natural state for the benefit of all Americans." SUWA also "provides leadership within the conservation community through uncompromising advocacy for wilderness preservation" although the organization claims that it supports other unnamed protective designations where appropriate. Tellingly, success is not measured by passage of any wilderness legislation but by defeat of anti-wilderness proposals, increases in membership, and record support for America's Redrock Wilderness Act (SUWA 2003b).

In addition to quarterly newsletters, SUWA currently publishes two booklets on the subject of wilderness in Utah. These publications are of a completely different 
nature than Wilderness at the Edge, the 400-page tome published by the UWC after the original BLM inventory in the style of an environmental impact statement. This type of detailed evaluation has given way to a different style where the minutia of analysis is not presented for public consumption. The current publications speak to and for a completely different audience of national scope.

One of the two booklets is titled Facts about America's Redrock Wilderness (SUWA 2003c), and is the more nuts and bolts compilation of information. Unlike more academic discussions of wilderness preservation, SUWA works from the premise that the existence of wilderness as a place is not in dispute. It is out there. There is an implicit assumption that all like-minded people would also take the existence of wilderness on faith. As SUWA sees it, wilderness is valuable for three main reasons. First, it is an important part of Utah's changing economy, with natural resource extraction being replaced by tourism and services. The work of Thomas Michael Power (1996) is cited in support of these economic benefits. As Power documents, natural resource extraction is now a small part of the economy from a statewide perspective. Wilderness is an amenity important for drawing new residents and business to the former homes of natural resource extraction. Damage to the environment will have deleterious consequences on the service-oriented businesses that are the cornerstones of a new economy. The second reason wilderness is valuable is that it protects desert wildlife. Wildlife are not simply of intrinsic value or ecologically important, but also integral to a wildlife-associated recreation economy, and wilderness designation is the best way to protect habitat. Conservation of 
biodiversity requires large preserved areas, as well as connectivity and corridors.

Finally, wilderness provides the best protection of prehistoric archaeological treasures. If one is interested in these values, then one is also interested in wilderness preservation.

While laying out the facts about wilderness, SUWA establishes the most broad of identity frames: They are the voice of the citizen. And they are defending federal public lands that are collectively owned by all taxpayers, not the nearby local residents. These lands should be managed with the public interest in mind and that interest is wilderness preservation. SUWA notes that even in conservative Utah, testimonials at statewide wilderness hearings and recent surveys have shown that most residents want wilderness, and lots of it. As former executive director Brant Calkins puts it, "If there is anything of which I think we are all too often guilty, it is underestimating the desire of the American people to save our lands and wildlife" (Groene 1999). SUWA sees the wilderness preservation community as the majority. They are not just a small group of extremists that opponents often depict them as, predominantly urban outdoor elitists who emphasize primitive recreational pursuits. They are Americans, Utahns, lovers of the outdoors for all manner of reasons, urban and rural alike. SUWA has no problem speaking for these "hypothetical typical Americans" (Goodman and McCool 1999, 181).

The opposition to SUWA is the faceless forces of development. SUWA sets the argument as public versus private with citizens on one side and corporations, facilitated by local politicians, on the other. As some have noted, it is very nearly a 
question of good versus evil (Goodman and McCool 1999). Every specific attack appears to threaten the entire wilderness preservation system. SUWA laments that wilderness, both designated and potential, is being whittled away by development, exploited for short-term profit, under siege. The three main threats are oil and mining exploration, off-highway vehicle use, and the anti-wilderness tool of road designation. Seventy-five percent of the photographs in the facts booklet portray roads or environmental damage caused by OHVs. SUWA does make a distinction between the resource (ab)users and the average local resident of rural Utah. Despite their often strong opposition to wilderness, it is felt that most rural residents do not desire to destroy the land; they simply have little understanding of what the concept of wilderness means (personal communication with SUWA 2002).

SUWA's discourse reflects recent scholarship that suggests environmentalism is now the dominant societal critique of capitalism (Worster 1993a; Flores 2001). To these environmental historians, the problem with capitalism lies in the fundamental relationship between humans and the natural environment, one of exploitation not conservation. Growth and materialism are seen as virtues and ideals, not as greed and selfishness, and economics dominate the debate. Environmentalism questions the possibility of endless growth and overconsumption and worries about the consequences. As SUWA presents the case, exploitation of the pristine wilderness lands of Utah becomes an egregious example of capitalist greed.

The arguments that SUWA expounds are focused less on wilderness than on society, not a defense of wild nature so much as the need to protect against the 
historical likelihood of humans inflicting damage on the environment. Wilderness is not defined naturally or inherently but indirectly as "undevelopment". It is a tesponse against exploitation of nature, a restraint, not a response for nature. However, as Timothy Luke (1999) asserts, such a fight against abusive use of public lands implicitly supports an acceptable use of these lands, one of sustainability. Wilderness remains just one of the multiple uses, albeit different from the dominant exploitative use.

The second of the two booklets, America's Redrock Wilderness: Protecting an American Treasure (SUWA 1998), is predominantly a photo essay, interspersed with more poetic and less policy-oriented arguments for wilderness. The photographs work to create an iconography of the austere beauty of the desert. The images represent Utah BLM wilderness as what Ansel Adams called "a mystique: a valid, intangible, nonmaterialistic experience" (quoted in Luke 1999, 28). Wilderness is sacred space. Here, the natural world is more intense and orderly than common experience, with a sense of spectacle. The photographs from San Juan County include an oft-seen image of a slot canyon with seemingly unnatural light, an arch in the Nokai Dome region, sunset light on Monument Valley-like sandstone towers near Canyonlands, and the Anasazi ruins and rock art of Cedar Mesa. What is notably absent in the images is the endless miles of blackbrush on Mancos Mesa, or the pinyon and juniper woodlands of Cedar Mesa extending off to the horizon, or the harsh glare of the midday sun reflecting off the slickrock. Every place is inviting and there is no sense of a harsh environment or heat. The photographs do not just reproduce the wilderness, they create it. Ironically, prehistoric manmade structures and artwork have become icons of 
southeast Utah and represent its wildlands. They are part of the composed landscape but blend in almost naturally, and seem to represent something more than themselves, more than Native-American culture. The cliff dwellings are metaphors for humans living in balance with nature, even if they may have been abandoned because of ecological disaster.

Accompanying the images, personal aesthetic and moral viewpoints describe the intangible resources available in wilderness. Wilderness holds spiritual qualities and its existence represents a sense of fairness and humility towards nature as well as future generations of humans. Again, the context is the imminent destruction of the wilderness and its preservation as a different paradigm from that of capitalism, a superior perception of the world. As writer Barry Lopez is quoted as saying "We are not debating 'wilderness' here in trying to decide the fate of Utah's undeveloped public lands. The term is too restrictive. We're debating the future direction of Western civilization ... (quoted in SUWA 1998, 52)”.

Given the manner in which it frames the conflict over wilderness designation, it comes as no surprise that SUWA prefers the legal process as its conflict management mode. A 1994 article delineated a number of reasons why the organization takes a no compromise approach and will not participate in collaborative conservation efforts. Consensus only works if the groups involved shate some sense of agreement, and the sides in the Utah wilderness debate are clearly philosophical opposites. They feel that consensus-building efforts support the status quo, i.e., no wilderness, and act as stalling mechanisms while often illegal environmental 
destruction continues. SUWA will not be co-opted and lay down their legal "weapons" in a show of good faith in negotiating. They will not negotiate with lawbreakers and will use the full force of the law. Lawsuits both compel bad bureaucrats and allow good bureaucrats to do the right thing. If this approach is considered extremism, then SUWA is willing to be labeled extremists (SUWA 1994).

These tactics have certainly come under criticism for perpetuating the gridlock in the wilderness debate. As expected, opponents of wilderness designation do not much care for SUWA's approach. As James Parker, former Utah BLM director, states, "Why would an organization whose very existence is based on its ability to create and maintain controversy, want to see the wilderness debate conclude? The answer is obvious, it wouldn't." (Parker 1995). Even a former member has gone on record attributing the stalemate in the wilderness debate as much to SUWA's approach as to its opponents (Severance 2000). According to this disillusioned wilderness activist, several decisions made in the 1980's during the organization's early years have served to institutionalize the debate over wilderness legislation. The first was nationalizing the discussion. In doing so, a perceived dismissal of local concerns has fostered polarization between rural and urban Utah that has intensified to the point of being irreversible. The second decision was accepting only one wilderness bill for the entire state. Multiple wilderness bills, an approach taken in many other states, over a substantial period of time were unacceptable. These decisions, combined with the later development of a no compromise position and increased acreage numbers, has rendered discussion impossible. 
This uncompromising advocacy is the organization's most distinguishing characteristic. Brant Calkins states that sometimes environmentalists confuse passing a wilderness bill with protecting wilderness. He says, "you can pass a bad bill anytime, a good bill takes time... If it's in my lifetime, fine, if not, fine.” Wilderness advocates should not settle for a bad compromise, and expect to come back for more. As Calkins says, "We passed a Utah Forest Service bill in 1984 and nothing has happened since except too much land has been lost to chainsaws" (Groene 1999). Piecemeal conservation efforts exist within and accept the dominant system of natural resource exploitation and SUWA will have no part of them. For SUWA, it is all or nothing. And as Utah Representative James Hansen has said, "Those folks from SUWA are tough bastards to fight" (quoted in Goodman and McCool 1999, 75). 


\section{THE WILDERNESS PROBLEM: WHOSE CANYONLANDS?}

We could do what is being done all over the West and get together and learn from each other and make decisions together, or we can continue to hate and misunderstand. Then the future will be forced on us by someone else." (Claite Dorgan 1999)

The conflict in Utah mirrors other difficult to resolve debates over public land policy throughout the West. To understand these conflicts, one must consider many interacting factors, including historical and political changes, landscape characteristics, and ideas about the best use of public lands. These different layers of place can be analyzed separately or together as an overlay to identify patterns with explanatory power particular to this region and the wilderness issue. When this place, San Juan County, is examined in its entirety, a number of patterns emerge which, if recognized and acted upon, could provide a means for breaking the deadlock in the wilderness debate.

\section{A Battle of Ideas}

The opposing groups in the debate over wilderness designation are both fighting against what they see as the dominant culture. The local residents resist federal control and the influence that envitonmentalists have over national constituencies. The environmentalists fight against a cultural paradigm of economic growth and exploitation. These are not different answers to the same questions but a completely 
different framing of the issue. They do not see the landscape as it is, but as they make it, allowing in only those things that coincide with their stories.

Defending a Mythic Way of Life. San Juan County is isolated by its geography and culture, and bucks many of the regional trends across the west. It remains removed from the "New West" of Jackson, Wyoming or Telluride, Colorado, or even Moab, Utah to the north. The county is not a magnet for those looking to retire or seeking professional employment. There are few newcomers and none of the resulting change in demographics and settlement patterns that newcomers bring. Despite its stunning landscape, it is not tourism-oriented, or even particularly welcoming to outsiders. But it has a cohesive community and culture, born of the influence of Mormonism. These insiders ascribe to societal purposes that are fundamentally different from and incompatible with those of outsiders, such as environmentalists. In such a place as San Juan County, resistance to change is to be expected.

These local residents see the landscape through the lens of the western paradox: a place of freedom, individualism, and escape from society coupled with an endless economic growth through exploitation of federal lands. They view things at a small scale, where the benefits of the development of natural resources to the local economy are directly felt and the impacts on the environment are perceived to be small in comparison. Much of the local resident's thetoric is couched in terms of defense of traditional multiple use of public lands, such as ranching and mining, and legal rights to public land access. There is also a sense that, because they live near these 
federal lands, it is only fair that they should have more say and control over how those lands are used.

In the face of objective facts, some of these perceptions have no real basis in reality. The impacts of human activity on the environment of San Juan County have been vastly overstated by the opponents of wilderness. Only those who imagine stillto-be-discovered tiches undetlying all the lands of southeast Utah can deny the existence of vast expanses of wild lands. The county commissioners even admitted as much by making a wilderness proposal in 1995 . Figure 19 shows that most of the land under consideration as wilderness could be designated as such to the detriment of no one. Wilderness designation is by no means an unreasonable approach, and will not stymie economic activity. Global economic forces have already done that to the mining industry, and cattle ranching on desert lands will always be a marginal activity. The coming of the next economic boom is wishful thinking at best. The antiwilderness dialogue expresses an ignorance of public land history and resource exploitation throughout the West.

For people who have made a living from these federal lands for generations, there is surprisingly little concern for the environment. Perhaps it is the sheer size of the landscape, and the smallness of any human presence, that renders environmental concerns insignificant. How can such a landscape be damaged? On the hand, these wild lands may not matter at all within the anthropocentric world view of the county residents. It is a difficult, not a bountiful land, as one might expect from the desert, and a few pretty places aside, mostly a wasteland. What is its potential to be something 
else? How can it best be conquered? The San Juan County Master Plan recognizes that county residents value a "rural lifestyle characterized by pastoral landscapes, open spaces, and small town qualities" (BLM Utah 2002). It is these developed landscapes that people love; livelihood is more important than scenery. The wild lands of the county are only the scenic context for civilization.

Defending the Wild. The existence of large tracts of wild lands does not mean that SUWA's own ideological arguments are beyond reproach. Three main problems are apparent. For one, pending destruction of the environment has yet to be realized. By SUWA's own admission, less than one percent of the land found to have wilderness characteristics in the early 1980's no longer had them in the late 1990's. Until a recent surge in oil and gas exploration, development had ceased on most potential wilderness lands in Utah. There are many reasons for this, not least of which is SUWA's continued efforts to protect those wild lands. Preservation remains in uneasy coexistence with the dominant cultural paradigm of economic growth. But there is still a sense of overstatement in SUWA's rhetoric. An attack on one particular place becomes an attack on the entire wilderness preservation system. The idea that wilderness is the only level of protection that really works to preserve the land may not be true.

A second problem is that SUWA frames the wilderness issue at the state and national level where the discussion is one of broad concerns and perceptions of the environment and nature rather than one of specific places. Economic arguments are also state and national in scope, where the impact of traditional resource extraction 
activities on the economy is approaching statistical insignificance. However, in fural areas, those statistics still translate into the loss of real jobs. This situation may be a harsh reality, but disregarding the impact can certainly be construed as callous, and is unlikely to foster a local constituency that supports wilderness designation.

Lastly, all lands proposed for wilderness are not equally wild as shown in Figure 19. Clearly, some are wilder and prettier than others, and these are the lands that represent Utah wilderness in photographs. Most people would not know that these images of strikingly beautiful canyons and spectacular geological formations show a landscape that is often the exception rather than the rule. The less photogenic mesatops are no less ecologically important. They just happen to support a commonly held predisposition that the desert is a monotonous wasteland. And as it turns out, most of the recent additions to the citizens' inventories are these mesatops, not canyons, and they are typically found closer to roads, population centers, and areas of heavy visitor use.

William Graf summarizes this ideological duel well, indicating that greed has been a powerful driving force:

"From commodity developers to wilderness preservationists, all the participants in the policy debates have gone to great lengths to ensure that their particular views of land management are extended to as much of the federal lands as possible. Each group has endangered its credibility and effectiveness when its political reach has exceeded its logical grasp." $(1990,261)$ 


\section{Rethinking the Approach}

Seven Regions, One State. While the two opposing groups appear to simply entrench themselves further, the middle is left to the BLM, and the agency is pushed and pulled in every direction. Prior to FLPMA, such conflicts of interest did not exist; the BLM was a resource user's management agency. As more diverse mandates for land management have been thrust upon the BLM, it has been grudgingly forced to consider environmental protection as one of the multiple uses. Slowly, institutional thinking has been changing. The difference between the first and second inventories is perhaps the best evidence of this institutional change. By most accounts, the BLM's second inventory was as fair and evenhanded as the first inventory was biased. However, it would be a misrepresentation to say that there is a consistent and progressive change in organizational outlook. The prevailing political wind can change direction at any moment, especially for a multiple-use agency. Any particular bureaucratic approach is subject to change every four years.

Although not yet published, the Utah BLM's new tactic for wilderness analysis, one that divides Utah into seven regions, is a much needed change. The regional approach recognizes the importance of geography, and reflects the physiographic and biotic variability of the Colorado Plateau. It addresses the wilderness issue at a smaller scale where it becomes somewhat less complicated. On the order of twenty potential wilderness areas are considered at once rather than hundreds. The BLM's new discourse reflects resource issues pertinent to a particular area. For example, uranium mining has been and remains relevant only in southeast Utah, while coal development, 
important elsewhere, is a minor issue in the southeast. The consideration given to alternate resource availability is also a key component; every resource does not need to be developed in every area.

A smaller scale also can subordinate the ideological to the practical and address specific local needs. But this kind of detailed analysis at the local level can also be a myth-busting exercise. For example, this study illustrates that places of potential economic opportunity and potential wilderness for the most part do not overlap. A large percentage of the land in the county is already devoted strictly to economic use, especially in light of its small population. Even the places that local residents are attached to and visit are not the same ones slated for wilderness designation.

Talk and Compromise. The lack of local support for wilderness designation is one of the biggest stumbling blocks to resolution of the debate. Framing the issue as a national problem, as SUWA does, effectively leaves the small local population out of the discussion. As the recent sagebrush rebellion and county supremacy movements have shown, a fundamental issue is local versus federal control. Simply ignoring this perspective assures that there will be little if any local support for wilderness protection.

Whether it is right or wrong, one surely must question the effectiveness of SUWA's "no compromise" approach. It is certainly much easier to stop legislation than to pass it. There is a distinct downward trend in the number and size of wilderness designations in the last ten years. In this political environment, passing a 9.1 million-acre wilderness bill seems unlikely, especially when proposals half that size 
could not pass during a time more conducive to wilderness designation. The Utah congressional delegation will simply not accept a wilderness bill as large as the current citizens' proposal, and such bills have never been passed without compromise. If this citizens' proposal is simply a negotiating ploy, as some have said, it calls into question the accuracy of SUWA's detailed analyses of wilderness characteristics.

It is certainly possible that the opposing groups have become polarized to such an extent that there is simply no middle ground available. Yet many intractable environmental conflicts throughout the West have broken deadlocks through collaborative efforts that seemed equally unlikely (Brick, et al. 2001). Piecemeal wilderness legislation born of compromise has been working in the conservative sagebrush rebellion state of Nevada. In fact, the only two major wilderness bills to be enacted in the last ten years have been for predominantly BLM land in Nevada (U.S Congress 2000 and 2002). The jury may still be out on collaborative conservation efforts, but it is a powerful trend that is ignored at risk.

One might ask whether it even matters if wilderness is designated or not. As noted earlier, in the time between the first and second BLM inventories, little potential wilderness was lost to development. The only thing that changed was the perception of whether the land had wilderness characteristics or not. The very nature of this isolated and inaccessible land combined with global resource availability makes future development less and less likely. Nevertheless, the interim protection afforded by over three million acres of wilderness study areas over the last twenty-five years cannot be ignored. Neither can the protection provided in the designation of Grand Staircase- 
Escalante National Monument. But these are still just a fraction of BLM lands in southern Utah having even interim protection. A continued stalemate over wilderness designation allows changes in the political direction at the national level to determine the fate of wildemess lands. Just as one could not have guessed that, of all agencies, the BLM would essentially admit to bureaucratic mistakes in its first inventory and actually find more wilderness, one can only guess at the future direction of federal land policy.

The Next Sagebrush Rebellion

The window of opportunity for wilderness designation between sagebrush rebellions may be closing. A new sagebrush rebellion, centered on vehicular access to public lands, may have already begun.

As recreation replaces resource extraction as the primary use of public lands, off-highway vehicle use is one of the preeminent threats to wilderness designation. This is especially true for BLM lands in southern Utah, where the open terrain encourages OHV use. Damage to the desert landscape can last for decades. Many areas now dedicated to OHV use were not evaluated for the appropriateness of that activity, but simply exist because incremental increases in use over time have displaced other uses. Since nonmotorized users of public lands can have their experience impaired by motorized users, while the opposite has been shown to not be true, shared access simply results in displacement of the former by the latter (Havlick 2002). 
In attempt to address and "catch up" with this rapidly growing form of recreation, the BLM recently developed a national strategy for managing OHV use (BLM 2001b).

County road claims made per R.S. 2477 of the 1866 Mining Law constitute the other half of the vehicular access debate. Exploration for minerals and oil has left a myriad of dirt roads crisscrossing the landscape. Largely unused, many are reverting to their natural state and can best be described as faint ways. Most wilderness unit boundaries follow the more heavily-traveled of these roads and ignore the ways. However, Utah counties have laid claim to many of these ways as vital transportation links for access to public lands. That contention would seem implausible to most who have driven on those so-called roads. A more likely explanation is one of philosophical differences. Any official designation of county roads on federal land would prove a powerful tool to prevent wilderness designation, since wilderness areas are by definition roadless.

The Blue Ribbon Coalition, formed in 1987, is comprised of an amalgamation of off-highway vehicle user groups with heavy support from manufacturers. This group is the primary national advocate against any restricted access to public lands, and receives money from many corporations in extractive industries such as timber, mining, and energy (Havlick 2002). Such support is a sure sign that the vehicular access issue is ready to become the latest incarnation of the long-standing conflicts over preservation versus use of public lands. 


\section{New Concepts for Public Lands}

Dominant Use. Politicians and scholars alike have called for a more sophisticated conceptualization of public lands (Babbitt 1991; Nelson 1995; Cawley and Freeworth 1997, Kemmis 2000). They invariably criticize the management practice of multiple-use and suggest that a transition to a concept of dominant use would be appropriate and logical. Babbitt writes that a dominant-use approach would allow evaluation of the marginal economic practices of resource exploitation in favor of recreation, wildlife and watershed protection.

One of the most significant flaws in the concept of multiple use is the disconnect between national political goals for public lands and actual implementation on the ground. It does not matter whether those goals are preservation or energy exploration. Lofty national goals often bear no relationship to what can or should be done in a particular place. As is evident in the Utah debate over wilderness, most disagreement has taken place over the use of these specific local areas. Many people may agree with the principle of multiple-use of public lands, just not in their area of vested interest. In fact, the passage of the Wilderness Act and other environmental legislation is testament to what little faith there is in true multiple-use planning.

The real problem with multiple use is that several of the so-called uses are not uses at all. Preserving land as wilderness, or for fish and wildlife, is an act of letting the lands be and not using them. The idea of no use runs counter to the idea of efficient economic use, the dominant paradigm of the last century. How can one possibly allocate lands for preservation in the same way that oil and gas leases are issued? They 
are separate and often competing social values. Just as limited access, such as that required by the Wilderness Act, restricts cettain uses, unlimited access results in a de facto dominant economic use.

In reality, the idea of dominant use may be no different than the original intent of the multiple-use doctrine. There has always been an allowance for the use of less than all available resources. For better or worse, congtessional designation of dominant-use areas would remove much of the discretionary power of the land management agency. The pretense of scientific land management would be replaced by an overtly political process. The argument would simply shift to one of how to determine the amount of land devoted to each use.

The Continuum of Wildness. Far from being just an intellectual exercise, thinking about how we conceptualize the natural world can have profound implications for natural resource management. Recognizing the existence of a continuum of wildness, as this study suggests, would allow a more holistic approach to land management. It could foster the use of different protected areas types with specific purposes beyond the national park and wilderness models. Rather than a multiple-use doctrine, this approach would be more akin to a principle of multiple levels of protection.

The BLM has a variety of other designations at its disposal. National Conservation Areas (NCAs) are a relatively new concept that may bridge the gap between wilderness and nonwilderness. Now that the BLM manages some national monuments, such as Grand Staircase-Escalante and Canyons of the Ancients, another 
protected area designation is available, even if the management goals for these national monuments are not well-defined. The BLM also uses Areas of Critical Environmental Concern (ACECs) as a management tool. Unfortunately, the public at large does not know where they are, and one needs to read a resource management plan to find them. Even wilderness study areas, although an interim protection, provide still another level of protection not quite as stringent as actual wilderness designation. Unfortunately, most of these types of protected areas are born of compromise, and what is missing is a clearly articulated purpose.

One could envision some of these different levels of protection for some of the lands proposed for wilderness designation. Although anti-wilderness groups often propose NCA's and ACEC's as alternatives to wilderness, that fact does not invalidate their potential value. If one accepts the idea of a continuum of wildness that include wilderness by definition, then such a management approach does not have to be seen as a substitute for wilderness designation.

Implicit in such a program would be the need for coordination across federal jurisdictional boundaries. If a place like San Juan County is conceptualized as a continuous region, it must be managed as such by the Bureau of Land Management, the Forest Service, and the National Park Service. The proposed expansion of Canyonlands National Park would incorporate all or parts of four BLM WSAs. Large parts of Glen Canyon National Recreation Area form logical extensions of the potential BLM wilderness areas of Nokai Dome, Mancos Mesa, and Dark Canyon. Squaw/Papoose Canyon and Cross Canyon WSAs should be part of the BLM's own 
Canyon of the Ancients National Monument. Even heavily-used Manti-LaSal National Forest has some potential wilderness areas if contiguous BLM parcels are considered. Even if one accepts the need for a variety of protected areas spread across this spectrum of wildness, a difficult task still remains. How much of the land actually falls within each band of the spectrum? Over what scale should the analysis occur? What about the element of time? Should areas with relatively insubstantial intrusions be allowed to recover? Difficult questions, to be sure, but better ones to try to answer than the current one, that of a simple yes or no to wilderness designation. These decisions about public lands are never truly objective and scientific but reflect very subjective social values. America's social hopes and ambitions have been and continue to be wrapped up in the public lands. A management doctrine that once was "the greatest good for the greatest number' has now come to mean all things to all people. One might then ask which social values will be deemed most important. The case for erring on the side of protection is made by Wayne Owens in the foreword to Wilderness at the Edge,

"If we do not deliberately protect our remaining wilderness in Utah, I fear that it will eventually disappear. It will not vanish through beneficial development, but will instead be lost through gradual attrition for no good reason at all." $(1990,1)$ 


\section{CODA}

On April 11, 2003, Secretary of the Interior Gale Norton renounced BLM authority to conduct wilderness reviews of public land to determine if they have wilderness character. A Department of the Interior (DOI) fact sheet states that,

"The settlement acknowledges that for BLM Congress has established in FLPMA the authority for creating WSAs. The settlement acknowledges that this process lapsed when the Section 603 WSAs were identified and recommendations were made to Congress." Any action to establish any other WSAs is beyond the BLM's authority." (DOI 2003a)

Without mentioning it explicitly, the settlement rescinded the 1999 Babbitt wilderness re-inventory, which confirmed that the BLM overlooked at least 2.6 million acres of . wilderness lands in its original inventory of the 1980s. All of these lands, which the BLM agrees have wilderness character and are eligible for protection, will now be open to development. The draft EIS prepared by the BLM for the southeast region of Utah will not see the light of day under this settlement.

Secretary Norton described the new policy as the settlement of the lawsuit that in 1996 challenged then-Secretary Babbitt's re-inventory of BLM lands. Although the $10^{\text {th }}$ Circuit Court of Appeals had overruled a District Court's injunction against the re-inventory in 1998 , the case had seen no further action. Only one claim remained when the lawsuit was revived just two weeks prior to the settlement. This claim challenged the interim management policy that effectively treated land under evaluation for wilderness characteristics as if it were designated wilderness. In recognizing the plaintiffs' case, the settlement revoked the BLM's newest Wilderness Inventory Handbook (2001). The handbook read that other lands, in addition to 
existing 603 WSAs, should be reviewed for wilderness characteristics. If found, then the lands would be managed so as not to impair those characteristics until studies are conducted through the public planning process to determine whether to protect them as wilderness study areas. Although it is this interim management policy that seems to be the main point of contention, the ramifications of the settlement are far greater than just interim management. The $10^{\text {th }}$ Circuit Court of Appeals ruling in 1998 was overturned by a lower court. Coincidently, SUWA, The Wildemess Society and other groups had filed a motion to intervene in the suit on April 8,2003, three days before the settlement was announced (SUWA 2003d). The same judge overruled by the 10 th Circuit Court in 1998 approved the settlement and never ruled on the motion to intervene.

As a result of the settlement, the BLM revised its scoping notices for five field offices in Utah that are in the process of revising resource management plans on what is generally a $15-20$ year cycle. These notices had included statements that new wilderness land protections would be considered based on its own inventories, but now state specifically that wilderness study area designation will not be considered. These changes were made despite the wording of Section 202 of FLPMA which states that the BLM shall use its inventories, required to be conducted per Section 201, as a basis for revision of its planning documents. Each administration since the enactment of FLPMA has recognized the BLM's authority to designate wilderness study areas under Section 202. Even the notoriously anti-environmental James Watt used that authority in the Reagan administration (Wilderness Society 2003). 
In May of 2003, one hundred congressional representatives and senators sent a letter to Secretary Norton stating their concern with the settlement and desire for her to reconsider (Hinchey, et al. 2003). They felt it was the intent of the settlement to preclude any further consideration of wilderness protection beyond areas so identified in the original 603 inventory, thereby limiting congressional options in their sole authority to designate wilderness, eliminating a BLM land management tool, tying the hands of future Interior Secretaries, and eliminating public input from the land management process. In another action of protest, ten environmental groups filed an appeal against the settlement in June (Wilderness Society 2003).

In a separate action in the same month, Secretary Norton and Utah Governor Mike Leavitt came to an agreement that made Utah the first state to establish a process for validating claims for the existence of roads under R.S. 2477 (DOI 2003b). In January, Interior Secretary Norton had issued new "disclaimer regulations" that would allow states and counties to file claims, and if deemed to be valid, the federal government would "disclaim" these roads and turn them over to state or local government. There are no provisions in the process for public involvement. The state of Utah has made more than 15,000 claims of rights-of-way and has funded counties to conduct road inventories, but to this date had been unsuccessful in validating those claims. SUWA and the Sierra Club won a major victory in U.S. District Court in 2001 when the judge rejected sixteen R.S. 2477 claims made by rural Utah counties, and held that to be valid R.S. 2477 claims must have been "constructed" and must be have an identifiable destination. The $10^{\text {th }}$ Circuit Court of Appeals upheld this victory in 
July of 2003 (Spangler 2003). The implications of the court decision on the Norton/Leavitt agreement are unclear.

The House of Representatives approved the new program in its appropriation bill for the Interior department in July of 2003, but removed national parks and monuments, national wildlife refuges, wilderness areas, and wilderness study areas from lands where disclaimers could be allowed. Representative Jim Matheson of Utah attempted to pass an amendment that would limit disclaimers to so-called "Class B" roads that can be driven by standard two-wheel drive vehicles, but it did not pass. (Smith 2003).

With the demise of the re-inventory and an aggressive program to establish rights-of-way claims on public lands, the prospects for continuation of the endless debate about wilderness in Utah seem good. However, if a recently introduced bill makes its way through Congress, the debate may soon be somewhat arbitrarily settled. America's Wilderness Protection Act was introduced in the House by Representative Butch Otter of Idaho as H.R. 1153 in March of 2003. The intent of this bill is to "accelerate the wilderness designation process by establishing a timetable for the completion of wildemess studies on Federal lands ..." with a goal to remove the interim Wilderness Study Area status from federal lands so designated by either designating them as wilderness or releasing the lands for other uses. The timetable for this act has wilderness study areas being released from that status after ten years from the enactment of the bill or when the Secretary of the Interior or Agriculture deems those lands as not suitable for wilderness designation. At first glance, and without 
taking note of the sponsors (Cannon of Utah, Simpson of Wyoming, Young of Alaska amongst others) this bill seems to be reasonable and neutral on the wilderness issue. But in the fine print, it defines wilderness study area broadly to mean not just the official status but any area under any kind of study as recommended, proposed or potential wilderness. And once released from WSA status, these lands shall not be studied again.

In light of the extended conflict in Utah with no change, establishing an artificial end date now is unreasonable. A clear release date for WSAs is as likely to foster delaying tactics by opponents to wilderness as much as it would action on wilderness designation. 


\section{ENDNOTES}

1. Section 603 of FLPMA required the BLM to conduct a wilderness inventory, analyze areas found to have wilderness characteristics, and make recommendations for wilderness designation by 1991. Wilderness study areas were designated in 1980 following the inventory phase. Wilderness study area status established by the Section 603 process can only be removed by Congress. Re-inventory study units were established when Interior Secretary Bruce Babbitt ordered a re-inventory of certain Utah BLM lands in 1996. These re-inventory study units could become wilderness study areas through the planning process outlined in Section 202 of FLPMA. This section states that the BLM shall use ongoing inventories of public lands as the basis for revision of its planning documents. If inventories find land with wilderness characteristics, the BLM can administratively designate those lands as wilderness study areas. Wilderness study area status established by the Section 202 process can changed by the BLM at any time.

2. Chaining is the mechanical removal of trees to convert pinyon and juniper woodlands to grasslands for livestock grazing. Two bulldozers pull a ship anchor chain between them, uprooting trees in the process. Other so-called range improvements techniques include either burning or spraying of shrubs with herbicides. Each of these processes is followed by re-seeding of the cleared land with grasses. Chaining was a common practice in the 1950's and 1960's, justified by the encroachment of junipers upon former grasslands due fire suppression and overgrazing (Grahame and Sisk 2002). Although a much less common practice since the 1970 's, chaining is still used to manipulate rangeland in Utah. Previously chained areas can be found in various conditions from open grasslands to fully-recovered woodlands, but more often than not they are noticeably unnatural-looking, with scattered piles of deadwood interspersed with occasional desert shrubs.

3. Photography is also an important medium through which aesthetic appreciation of the desert is expressed. Photographic images are not just a simple documentation of the natural world; hours of the often unrecognized artifice and skilled craft go into creating idealized images. Not unlike the written word, these images educate the viewer and present a vision of nature as more intense and orderly than common experience (Lawrence 2001). Ansel Adams is perhaps the most well-known nature photographer. Adams creates a sense of understanding the mystical meaning in nature that is beyond the representation of an object, something akin to the writing of Abbey. Eliot Porter another noted photographer, more of a documentarian than Adams, working on a smaller scale. In his book The Place That No One Knew, he documented Glen Canyon prior to its inundation by Lake Powell (Graber 1976). The photography of those such as Tom Till, Bruce Barnbaum, and Mark Klett has popularized the landscapes of the desert southwest to the point of establishing a new standard in the outdoors repertoire. 
4. To be sure, Utah is not devoid of Mormon environmentalists. Congressional Representative Wayne Owens, Utah Wilderness Coalition Chairman Larry Young, and the founder of the Glen Canyon Institute, Richard Ingebretsen, are a few notable examples. In a recent publication, editors Terry Tempest Williams, William Smart, and Gibbs Smith discuss the possibility of a renewal of the Mormon land ethic. They acknowledge a recent study of the environmental positions of the thirty largest Christian denominations in the United States, where the Church of Jesus Christ of Latter-day Saints falls into the category of being formally committed to inaction. The writers in this book, including some prominent members of the Mormon Church, urge a teevaluation of the human relationship with the earth, similar in vein with what is occurring in other Christian denominations. The environmental crisis is presented as a moral crisis. Mormons have for the most part lost any sense of sustainability or ecological awareness fostered by the original teachings of Joseph Smith and Brigham Young. They have acquiesced to the entrepreneurial spirit of mainstream America. Utah can reclaim some of its original sense of community by returning to an earlier thinking focused on stewardship of the land.

5. President Clinton unilaterally protected these lands using the authority given to Presidents under the Antiquities Act of 1906. The national monument status afforded a lesser degree of environmental protection than actual wilderness designation. This designation thwarted a coal mine proposal by Dutch-owned Andalex Resources on the Kaiparowits Plateau but did not stop exploratory oil and gas drilling by Conoco Oil, who ultimately came up empty. The negative reaction from all corners of the state was expected and immediate. Several counties in southern Utah proceeded to bulldoze roads into wilderness study areas, areas proposed for wilderness designation, and even within the new national monument. The counties claimed a legal right of way to any existing roads on federal land. $A$ fter authorizing the bulldozing of more than ten miles of road into Hart's Point wilderness re-inventory unit near Canyonlands, San Juan County Commissioner Bill Redd proclaimed "Until a judge tells us that they're not our roads, we're going to continue. Just because someone doesn't like it doesn't mean he can tell me to quit" (Watkins 2000, 111).

6. It is only with the improvements in technology in the 1980 s and the availability of user-friendly four-wheeled all-terrain vehicles has off-highway vehicle use become a major land management issue. Sales of OHVs have skyrocketed in the 1990s, outpacing the sales of street motorcycles. Corporations have marketed the vehicles beyond a core constituency of recreationists, touting a more democratic access to public lands, previously limited to the physically-fit elitist. Families can go on OHV outings and ranchers use them instead of horses. Prior to these technological improvements, OHV use (and abuse) was primarily limited to motorcycles, a small market that also requires a much higher level of skill to use (Havlick 2002). 


\section{REFERENCES}

Abbey, Edward. 1968. Desert solitaire. New York: Random House.

1977. The journey home: Some words in defense of the American West. New York: E.P. Dutton.

Aplet, Gregory, et al. 2000. Indicators of wildness: Using attributes of the land to assess the context of wilderness, in Wilderness Science in a Time of Cbange, McCool, S. et al. (eds). Ogden: U.S. Department of Agriculture, Forest Service, Rocky Mountain Research Station.

Austin, Mary. 1903. The land of little rain. Albuquerque: University of New Mexico Press (reprint).

Babbitt, Bruce. 1991. Public use and the future of the public lands, in $A$ society to match the scenery, Holthaus, G. et al. (eds). Boulder: University Press of Colorado.

Banham, Peter Reyner. 1982. Scenes in America deserta. Salt Lake City: Peregrine Smith Books.

Baudrillard, Jean. 1985. America. New York: Verso Books.

Birch, Thomas. 1990. The incarceration of wildness: Wilderness areas as prisons. Environmental Etbics 12: 3-26.

Brick, Philip, Snow, Donald, and Sarah Van de Wetering (eds). 2001. Across the great divide: Explorations in collaborative conservation and the American West. Washington DC: Island Press.

Bureau of Land Management. 1978. Wilderness inventory bandbook. Washington DC. 1999. Utah wilderness inventory. Washington DC. 2000 Revision to the 1999 Utah wilderness inventory-Southeast region. Washington DC.

.2001a. Wilderness inventory and study procedures bandbook. Washington DC.

2001b. National management strategy for motorized off-highway vebicle use on public lands. Washington DC.

2002. Public land statistics 2002. http://www.blm.gov/ natacq/pls02/ (last accessed 3/31/04). 
Bureau of Land Management Nevada State Office. 2004. Wilderness Fact Sheet. http://www.nv.blm.gov/nvwilderness/WildernessFactSheet.doc (last accessed $3 / 31 / 04)$.

Bureau of Land Management Utah State Office. 1979a. BLM proposed initial wilderness inventory. Salt Lake City.

. 1979b. BLM final initial wilderness inventory. Salt Lake City.

1980. BL M intensive wrilderness inventory: Final decision on wrilderness study areas. Salt Lake City.

. 1986a. Utab BLM statewide wilderness draft environmental impact statement. Salt Lake City.

1990a. Utah BLM statewide wilderness final environmental impact statement. Volume I Overview Salt Lake City.

. 1990b. Utah BLM statewride wilderness final environmental impact statement. Volume $V$ Southeast region. Salt Lake City.

.1990c. Utab BLM statewide wilderness final environmental impact statement. Volume VII Public Comments. Salt Lake City.

1991. Utab statewide wilderness study report. Salt Lake City.

1999a. Notice of intent to prepare a statewide environmental impact statement (EIS) and multiple plan amendments to consider establishment of new wilderness study areas (WSAs) on selected public lands in Utah, and call for information. Federal Register 64 no. 52 March 18.

. 1999b. Notice of intent to modify scope of a statewide environmental impact statement (EIS) and multiple plan amendments considering establishment of new wilderness study areas (WSAs) on selected public lands in Utah, and call for information. Federal Register 64 no. 212, November 3.

2002. Utah wilderness study area draft environmental impact statement/draft plan amendment- Southeast region. (unpublished).

Callicott, J. Baird. 1991a. The wilderness idea revisited: The sustainable development alternative. The Environmental Professional 13: 235-247. 
1991b. That good old-time wilderness religion. The Environmental Professional 13: 378-379.

1998. Earth's insights: A multicultural survey of ecological etbics from the Mediterranean Basin to the Australian Outback. Berkeley: University of California Press.

Callicott, J. Baird and Michael Nelson (eds). 1998. The great new wilderness debate. Athens: University of Georgia Press.

Cawley, R. McGregor and John Freeworth. 1997. A critique of the multiple use framework in public lands decision making, Western public lands and environmental politics, in Charles Davis (ed). Boulder: Westview Press.

Cronon, William. 1996. The trouble with wilderness; or, getting back to the wrong nature, in Uncommon ground, Cronon, W. (ed). New York: W.W. Norton.

Davis, Sanda K. 1997. Fighting over public lands: Interest groups, states, and the federal government., in Western public lands and environmental politics, Charles Davis (ed). Boulder: Westview Press.

DeLyser, Dydia. 1999. Authenticity on the ground: Engaging the past in a California ghost town. Annals of the Association of American Geographers 89: 602-632.

Denevan, William M. 1992. The pristine myth: The landscape of the Americas in 1492. Annals of the Association of American Geographers 82: 369-385.

DeVoto, Bernard. 1934. The West: A plundered province. Atlantic 169 (August): 255264.

. 1955. The West against itself, in Western paradox: A Bernard DeVoto conservation reader. New Haven: Yale University Press (2001).

Dorgan, Claire. 1999. Letter to the editor. San Juan Record July 7, 1999.

Doughty, Robin W. 1981. Environmental theology: Trends in Christian thought. Progress in Human Geograpby 5: 23-248.

Durbin, Richard. 1999. America's red rock wilderness act. $106^{\text {th }}$ Congress S. 861.

Entrikin, J. Nicholas. 1991. The betweenness of place: Towards a geograpby of modernity. Baltimore: The Johns Hopkins University Press. 
Eisenhauer, Brian W., Krannich, Richard S., and Dale J. Blahna. 2000. Attachments to special places on public lands: An analysis of activities, reasons for attachments, and community connections. Society and Natural Resources 13: $421-441$.

Evernden, Neil. 1981. The ambiguous landscape, Geographical Review 71: 147-157.

Fairfax, Sally. 1984. Beyond the sagebrush rebellion: The BLM as neighbor and manager in the western states, in Western public lands: The management of natural resources in a time of declining federalism, Francis, John $G$. and Richard Ganzel (eds). Totowa, NJ: Rowman and Allanheld.

Flores, Dan. 2001. The natural West: Environmental history in the Great Plains and Rocky Mountains. Norman: University of Oklahoma Press.

Francaviglia, Richard. 1978. The Mormon landscape: Existence, creation, and perception of a unique image in the American West. New York: AMS Press

Ginger, Claire. 2000. Discourse and argument in Bureau of Land Management wilderness environmental impact statements Poligy Studies Journal 28: 292-312.

Glacken, Clarence. 1967. Traces on the Rhodian shore: Nature and culture in western thought from ancient times to the end of the eighteenth century. Berkeley: University of California Press.

Goodman, Doug and Daniel McCool (eds). 1999. Contested landscape: The politics of wilderness in Utab and the West. Salt Lake City: University of Utah Press.

Graber, Linda. 1976. Wilderness as sacred space. Association of American Geographers Monograph Series. Washington D.C.: Association of American Geographers.

Graf, William. 1990. Wilderness preservation and the sagebrush rebellions. Lanham: Rowman and Littlefield Publishers.

Grahame, John D. and Thomas D. Sisk (eds). 2002. Canyons, cultures and environmental change: An introduction to the land-use history of the Colorado Plateau. http://www.cpluhna.nau.edu/ (last accessed 5/8/04).

Gray, Barbara. 2003. Framing environmental disputes, in Making sense of environmental conflicts: Concepts and cases, Lewicki, Roy, Gray, Barbara, and Elliott, Michael (eds). Washington DC: Island Press. 
Groene, Scott. 1999. Who dresses like a Deseret Industries clothes rack, was threatened by the Manson family, fixed Ed Abbey's truck, and saved more red rock than anyone else alive? Canyon Country Zepbyr August-September 1999. http://www.canyoncountryzephyr.com/archives/brant-calkin.html (last accessed 12/19/03).

Hansen, James. 1989. Utah public lands wilderness act. $104^{\text {th }}$ Congress H.R. 1501. 1995. Utab public lands management act. $105^{\text {th }}$ Congress H.R. 1745.

Harvey, Mark W.T. 1994. A symbol of wilderness: Echo Park and the American conservation movement. Albuquerque: University of New Mexico Press.

Hatch, Orrin. 1995. Utab public lands management act $105^{\text {th }}$ Congress S. 884.

Havlick, David G. 2002. No place distant: Roads and motorized recreation on America's public lands. Washington DC: Island Press.

Hays, Samuel P. 2000. A bistory of enviormmenal politics since 1945. Pittsburgh: University of Pittsburgh Press.

Hinchey, Maurice. 1995. America's red rock wilderness act. $104^{\text {th }}$ Congress H.R. 1500. 1999. America's red rock wilderness act. $106^{\text {th }}$ Congress H.R. 1732.

Hinchey, Maurice et al. 2003. Letter to Interior Secretary Gale Norton 5/23/2003. http://www.suwa.org/library/UHB_Letter.pdf (last accessed 12/19/03).

Jackson, Richard H. 1981. Utah's harsh lands, hearth of greatness. Utab Historical Quarterly 49: 4-25. 1995. Federal lands in the mountainous West, in The mountainous West: Explorations in bistorical geography, Wyckoff, W. and L. Dilsaver (eds). Lincoln: University of Nebraska Press.

Kay, Jeanne. 1995. Mormons and mountains, in The mountainous West: Explorations in bistorical geograpby, Wyckoff, W. and L. Dilsaver (eds). Lincoln: University of Nebraska Press.

Kay, Jeanne and Craig J. Brown 1985. Mormon beliefs about land and natural resources 1847-1877, Journal of Historical Geograpby 11, 253-267.

Kemmis, Daniel. 2001. This sovereign land. Washington DC: Island Press. 
Kliskey, Andrew. 1994. A comparative analysis of approaches to wilderness perception mapping. Joumal of Environmental Management 41: 199-236.

Krutch, Joseph 1952. The desert year. Tucson: University of Arizona Press (reprint).

Lawrence, Claire. 2002. Wilderness icons: The difficulty of representing the desert Critical Studies 15: 361-376.

Leopold, Aldo. 1925. Wilderness as a form of land use, in The great new wilderness debate. Callicott, J. Baird and Michael Nelson (eds). 1998. Athens: University of Georgia Press.

1949. A Sand County almanac. New York: Oxford University Press.

Limerick, Patricia Nelson. 1985. Desert passages: Encounters with the American desert. Albuquerque: University of New Mexico Press.

1987. The legacy of conquest: The unbroken past of the American West. New York: W. W. Norton and Company.

Loomis, John B. 1993. Integrated public lands management. New York: Columbia University Press.

Luke, Timothy W. 1999. The Wilderness Society: Environmentalism as Environationalism. Capitalism Nature Socialism 10:1-35.

Marsh, George Perkins. 1864. Man and nature: Or, pbysical geograpby as modified by buman action. Cambridge: The Belknap Press of Harvard University Press (reprint).

Maskit, Jonathan 1998. Something wild? Deleuze and Guattari.and the impossibility of wilderness, in Pbilosophies of place Light, Andrew and Jonathan Smith (eds). Lanham: Rowman and Littlefield Publishers.

McPherson, Robert S. 1995. A bistory of San Juan County: In the palm of time. Salt Lake City: Utah State Historical Society.

Meinig, Donald. 1965. The Mormon culture region: Strategies and patterns in the geography of the American West. Annals of the Association of American Geographers 55: 191-220.

Nagel, Thomas 1986. The view from nowhere. New York: Oxford University Press. 
National Parks Conservation Association (NPCA). 2004. Completion of Canyonlands National Park. http://www.npca.org/explore_the_parks/new_parks/ canyonlands.asp (last accessed 3/31/04).

Nash, Roderick. 1982. Wilderness and the American mind. New Haven: Yale University Press.

Nelson, Michael P. 1998. An amalgamation of wilderness preservation arguments, In The great new wilderness debate Callicott, J. Baird and Michael Nelson (eds). Athens: University of Georgia Press.

Nelson, Robert H. 1995. Public lands and private rights: the failure of scientific management. Lanham: Rowman and Littlefield Publishers.

Norton, W. 1998. Mormon identity and the landscape in the rural intermountain West. Journal of the West 37: 33- 43.

Otter, C.L. 2003. America's wilderness protection act. 108 ${ }^{\text {th }}$ Congress H.R. 1153.

Owens, Wayne. 1989. Utah BLM wilderness act. 101st Congress H.R. 1500: 1990. Foreword to Wilderness at the edge: A citizen proposal to protect Utab's canyons and deserts, Salt Lake City: Utah Wilderness Coalition.

Parker, James. 1995. Editorial. San Juan Record September 6, 1995.

Peterson, Charles. 1983. San Juan: A hundred years of cattle, sheep, and dry farms, in San Juan County, Utab: People, resources, and history, Powell, Allan Kent (ed). Salt Lake City: Utah State Historical Society.

Porter, Elliott. 1963. The place no one knew. San Francisco: Sierra Club.

Powell, Allan Kent. 1983. The Hole-in-the-Rock Trail a century later, in San Juan County, Utab: People, resources, and bistory, Powell, Allan Kent (ed). Salt Lake City: Utah State Historical Society.

Power, Thomas Michael. 1996. Lost landscapes and failed economies. Washington DC: Island Press.

Proctor, James D. 1996. Whose nature? The contested moral terrain of ancient forests, in Uncommon ground, Cronon, W. (ed). New York: W.W. Norton. 
1998. Environmental values and popular conflict over environmental management: A comparative analysis of public comments on the Clinton Forest Plan. Environmental Management 22: 347-358.

Robbins, William G. 1986. The 'plundered province' thesis and recent historiography of the American West. Pacific Historical Review 55: 577-597.

Rolston, Holmes. 1986. Philosopby gone wild: Essays in environmental philosophy. Buffalo: Prometheus Books.

Ross, Janet. 1995. Letter to the editor. San Juan Record October 18, 1995.

Roylance, Ward J. 1971. New world and millennial dream. The Enchanted Wilderness First issue. Salt Lake City: Enchanted Wilderness Association. http://www.utahredrocks.com/ward.htm (last accessed 12/19/03.)

Rudzitis, Gundars. 1996. Wilderness and the changing American West. New York: John Wiley and Sons.

Rusho, W.I. 1983. Everett Ruess; A vagabond for beauty. Salt Lake City: Gibbs Smith Publisher.

Sack, Robert 1997. Homo geographicus. Baltimore: The Johns Hopkins University Press.

San Juan County. 1999. Response to Utah BLM wilderness re-inventory. (unpublished).

San Juan County Community Development. 2003. San Juan County Heritage. http://www.southeastutah.org/ (last accessed 12/19/03).

San Juan Record. 1995a. February 22, 1995.

1995b. April 5, 1995. . 1995c. June 14, 1995. . 1996. February 14, 1996. . 1999. October 27, 1999. 2000. April 19, 2000. 
Severance, Owen 2000. Why I don't belong to the Sierra Club or the Southern Utah Wilderness Alliance. Canyon Country Zepbyr October-November 2000. http://www.canyoncountryzephyr.com/archives/dontbelong.html (last accessed).

Smith, Christopher. 2003. Leavitt-Norton rural roads deal clears the House. Salt Lake City Tribune July 18, 2003.

Smith, Henry Nash 1950. Virgin land: The American West as symbol and myth. Cambridge: Harvard University Press.

Snyder, Gary 1990. The practice of the wild. New York: North Point Press.

Soule, Michael. 1995. The social siege of nature, In Reinventing nature?: Responses to postmodern deconstruction. Soule, M. and Lease, G. (eds). Washington DC: Island Press.

Southern Utah Wilderness Alliance. 1994. Why one advocacy group steers clear of consensus efforts. High Country News 26 no. 10.

1998. America's redrock wilderness: Protecting a national treasure. Salt Lake City: Southern Utah Wilderness Alliance.

1999. Comments to Utah BLM wilderness re-inventory. (unpublished).

. 2003a. Fruition of the new citizens' inventory of Utah wilderness. http://www.suwa.org/new_inventory/ (last accessed 12/19/03).

. 2003b. About SUWA. http://www.suwa.org/page.php?page_name= about_intro (last accessed 12/19/03)

2003c. Facts About America's redrock wilderness. Salt Lake City: Southern Utah Wilderness Alliance.

. 2003d. State of Utah, others sue to attack Utah wilderness. Press Release April 8, 2003. http://www.suwa.org/library/April8_2003.htm (last accessed 12/19/03).

Spangler, Donna Kemp. 2003. Utah trails aren't roads. Deseret Morning News July 2, 2003.

Starrs, Paul. 1998. Let the cowboy ride: Cattle ranching in the American West. Baltimore: The Johns Hopkins University Press. 
Stegner, Wallace. 1954. Beyond the bundredth meridian: Jobn Wesley Powell and the second opening of the West. New York: Penguin Books (reprint).

1969. The sound of mountain water. New York: Penguin Books (reprint).

1990. Introduction, in Wilderness at the edge: A citizen proposal to protect Utab's canyons and deserts. Salt Lake City: Utah Wilderness Coalition.

1991. A geography of hope, in $A$ society to match the scenery, Holthaus, $\mathrm{G}$. et al. (eds). Boulder: University Press of Colorado.

Trimble, Stephen and Terry Tempest Williams (eds). 1996. Testimony: Writers of the West speak on behalf of Utab wilderness. Minneapolis: Milkweed Editions.

Turner, Frederick. 1983. Beyond geograpby: The western spirit against the wilderness. New Brunswick: Rutgers University Press.

United States Census Bureau. 2004. Fact sheet: Highlights from the Census 2000 Demographic Profiles, San Juan County, Utah. http://factfinder.census.gov (last accessed 3/31/04).

United States Congress. 1866. Mining Law. 14 Stat. 251.

1934. Taylor Grazing Act. P.L. 73-482.

. 1964. Wilderness Act. P.L. 88-577.

. 1969. National Environmental Policy Act. P.L. 91-190.

1976. Federal Land Policy and Management Act. P.L. 94-579.

1984. Utah Wilderness Act. P.L. 98-428.

. 1984. Arizona Wilderness Act. P.L. 98-406.

2000. Nevada Black Rock Desert-High Rock Canyon Emigrant Trails National Conservation Area Act. P.L. 106-554.

2002. Nevada Clark County Conservation of Public Lands and Natural Resources Act.

P.L. 107-282.

United States Department of the Interior 2003a. Utah wilderness settlement fact sheet: Historical context behind the Utah wilderness settlement. DOI factsheet. http://www.doi.gov/wilderness/factsheet (last accessed 12/19/03). 
2003b. Interior and state of Utah reach landmark agreement on R.S. 2477 rights of way issue. DOI News April 9, 2003. http://www.doi.gov/news/ 030409a.htm (last accessed 12/19/03).

Utah Department of Natural Resources. 1992. Geological resources of San Juan County, Utah. Utah Geological Survey Public Information Series 14.

Utah Division of Travel Development 2003. Grand and San Juan County tourism profiles. http://travel.utah.gov/countyprofiles.html (last accessed 12/19/03).

. Utah Wilderness Coalition 1990. Wilderness at the edge: A citizen proposal to protect Utab's canyons and deserts. Salt Lake City: Utah Wilderness Coalition.

Vale, Thomas and Geraldine Vale. 1989. Western images, Western landscapes: Travels along U. S. 89. Tucson: University of Arizona Press.

Vale, Thomas. 1998. The myth of the humanized landscape: An example from Yosemite National Park. Natural Areas Journal 18: 231- 236.

Van Dyke, John C. 1901. The desert. New York: Peregrine Smith Books (reprint).

Vest, J.H.C. 1987. The philosophical significance of wilderness solitude. Environmental Ethics 9:303-330.

Watkins, T.H. 2000. The redrock chronicles: Saving wild Utah. Baltimore: The John Hopkins University.

Weiler Walka, Ann 1996. The unknown river, in Testimony: Writers of the West speak on behalf of Utah wilderness, Trimble, Stephen and Terry Tempest Williams (eds). Minneapolis: Milkweed Editions.

Wheeler, Ray. 1988a. Southern Utah: Stroke and counterstroke, in Reopening the western frontier, Marston, Ed (ed). Washington DC: Island Press. . 1988b. Southern Utah: The trauma of shifting economies and ideologies, in Reopening the western frontier, Marston, Ed (ed). Washington DC: Island Press.

White, Lynn. 1967. The historical roots of our ecological crises. Science 155: 12031207.

White, Richard. 1991. It's your misfortune and none of my own: A new history of the American West. Norman: University of Oklahoma Press. 
Wild, Peter. 1999. The opal desert: Explorations of fantasy and reality in the American Southwest. Austin: University of Texas Press.

Wilderness Information Network. 2004. Wilderness data. http://www.wilderness. net $/$ index.cfm? fuse $=$ NWPS\&sec $=$ advSearch (last accessed 3/31/04).

Wildemess Society. 2003. A citizen's reference guide: The Bureau of Land Management's continuing obligation to inventory and protect wilderness values. http://www.wilderness.org/OurIssues/BLM/wilderness.cfm\# (last accessed $12 / 19 / 03)$.

Wilkinson, Charles. 1992. Crossing the next meridian. Washington DC: Island Press. 1999. Fire on the plateau. Washington DC: Island Press.

Williams, Terry Tempest. 2001. Red: Passion and patience in the desert. New York: Pantheon Books.

Williams, Terry Tempest, Smart, William B. and Gibbs M. Smith (eds). 1998. New Genesis: A Mormon reader on land and community. Salt Lake City: Gibbs Smith Publisher.

Woods, Mark 1998. Federal wilderness preservation in the United States: The preservation of wilderness?, in The great new wilderness debate, Callicott, J. Baird and Michael Nelson (eds). Athens: University of Georgia Press.

Worster, Donald. 1992a. New West, true West, in Under western skies: Nature and bistory in the American West. New York: Oxford University Press. 1992b. Beyond the agratian myth, in Under western skies: Nature and bistory in the American West. New York: Oxford University Press.

1992c. Freedom and want: The western paradox, in Under western skies: Nature and bistory in the American West. New York: Oxford University Press.

. 1993a. The wealth of nature, in The wealth of nature: Environmental history and the ecological imagination. New York: Oxford University Press.

. 1993b. John Muir and the roots of American environmentalism, in The wealth of nature: Environmental bistory and the ecological imagination. New York: Oxford University Press.

Wright, John B. 1993. Rocky Mountain divide: Selling and saving the West. Austin: University of Texas Press. 
Wyckoff, William and Karen Hansen. 1991. Settlement, livestock grazing, and environmental change in Southwest Montana, 1860-1990. Environmental History Review 15: 45-71. 


\section{APPENDIX: GIS METHODS}

The cartographic model used for GIS analysis is shown in the figure on the following page. Each of the numbered steps in the model is described in detail below.

1. Slope. One-degree 90-meter digital elevation models (DEMs), based on data from the United States Geological Survey (USGS), were obtained from the Utah Automated Geographic Reference Center (UAGRC) (http://agtc.gov/agtc_sgid/sgidlib/ statewide_shp.htm). Five datasets covered San Juan County: Cortez West, Moab West, Escalante East, Escalante West, and Salina East. The DEMs were mosaiced, clipped to the boundary of San Juan County, and then slope was calculated. To smooth variation and provide better separation between canyon and mesatop areas, the median of slope was calculated using a neighborhood of $10 \mathrm{X} 10$.

2. Land Use. One-degree land use/land cover (LULC) datasets in ArcInfo format, based on data from the USGS, were obtained from the EPA (http:// www.epa.gov /ngispgm3/spdata/EPAGIRAS). Four datasets covered San Juan County: Cortez, Moab, Escalante, and Salina. The LLLC datasets were mosaiced, clipped to the boundary of San Juan County, and then the features were rasterized.

3. Minerals. A minerals dataset $(1: 500,000)$ was obtained from the UAGRC for the entire state. These mineral data were a point layer based on information from the Commodity Resource Information Board with locations provided by the Utah Geological Survey. The dataset was clipped to the boundary of San Juan County. The impact of mineral availability was classified based on the level of activity and development. This approach recognized the visual impact of previously mined areas as well as potential for current and future extraction. The following values were assigned based on the status of known deposits: 10- active developed, 8- intermittent, 6inactive developed, active little developed, 4-inactive little developed, 3-active prospect, 1 - inactive prospect. Values were also assigned to the size of deposits as follows: 3- large, 2- medium, and 1- small. The status values were multiplied by the size values to obtain a measure of the impact of the existence of mineral deposits. A mineral impact density (per square kilometer) was calculated using a search radius of 10 kilometers.

4. Energy. An energy resources dataset $(1: 500,000)$ was obtained from the UAGRC for the entire state. These energy resources data were a polygon layer based on data from the Utah Geological Survey. The dataset was clipped to the boundary of San Juan County. The impact of energy availability was classified based on the certainty of the resource and its likelihood of development. The following values were assigned: 5known oil and gas fields, 3- high probability of oil-impregnated rock, 2- coal outcrops, 1 - deeply buried coal and probable oil- impregnated rock. Values were also assigned to 
Cartographic Model for GIS Analysis
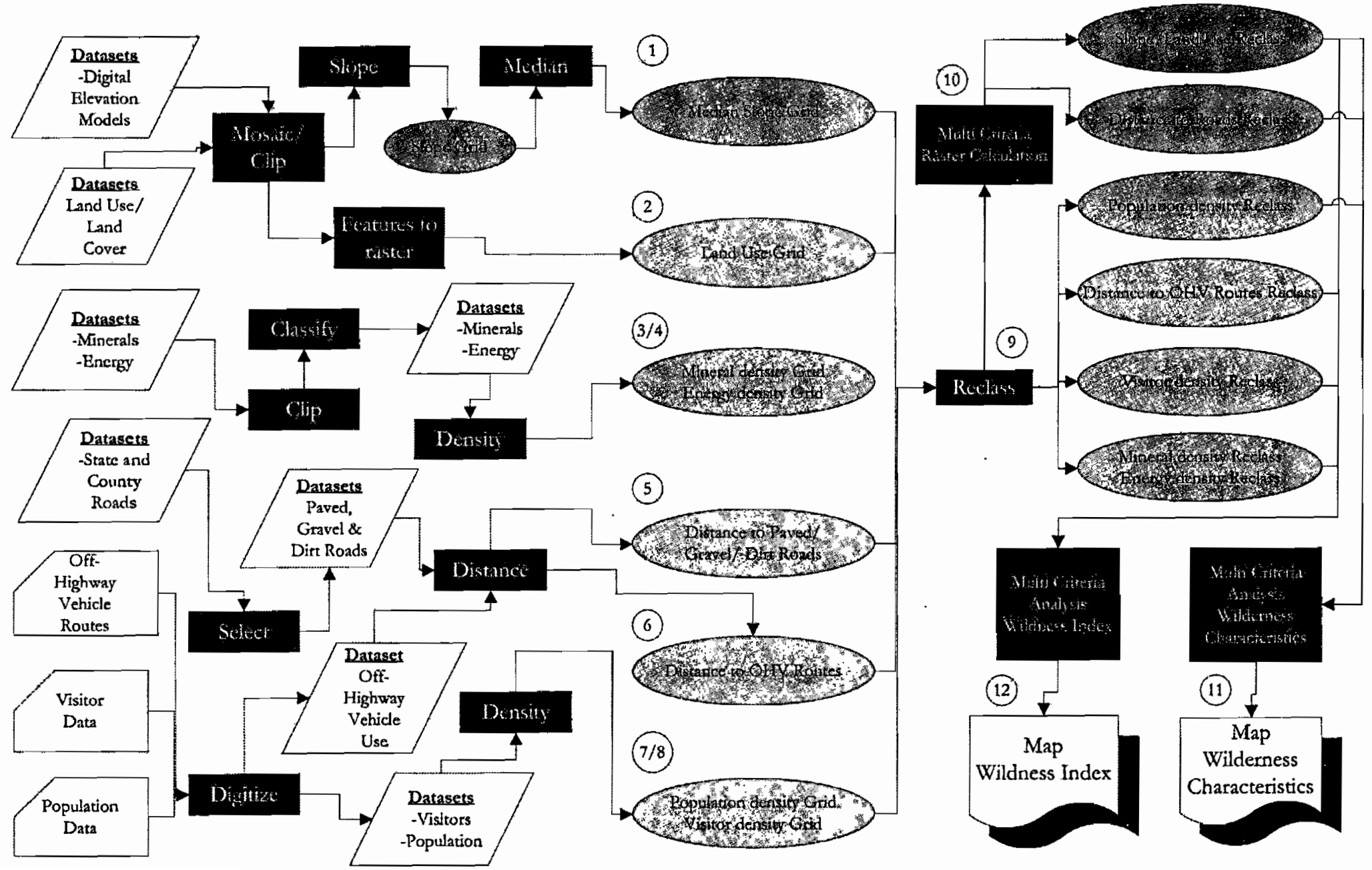
the size of the deposit (square meters) as follows: $5 /$ more than $100,000,000,4 /$ $10,000,000-100,000,000,3 / 1,000,000-10,000,000,2 / 100,000-1,000,000,1 /$ less than 100,000 . The certainty/likelihood of development values were multiplied by the size values to obtain a measure of the impact of the existence of energy resources. These calculated values were assigned to the centroids of each polygon in the layer. An energy impact density (per square kilometer) was calculated using a search radius of 10 kilometers.

5. Roads. Two roads datasets were obtained from the UAGRC. One displayed paved and major gtavel roads for the entire state $(1: 100,000)$ and was created from USGS Digital Line Graphs. The other dataset $(1: 24,000)$ was created by San Juan County from Global Positioning System measurements. Different levels of impact are expected for different types of roads, with paved roads being the most heavily used and highest expected impact, and dirt roads being the least used and lowest expected impact. The state dataset was clipped to the boundary of San Juan County and separated into two datasets, paved and gravel roads. A separate distance calculation was performed for each. These paved and gravel roads were then extracted from the county roads dataset and distance was calculated to the remaining dirt roads.

6. OHV Routes. Off-highway vehicle use information for San Juan County was obtained from the Monticello Office of the Utah BLM (http://www.blm.gov/utah/ monticello). Sixteen routes used for a countywide All-Terrain Vehicle Safari September 25-27, 2003 were digitized from a map published on the BLM website at a scale of 1:250,000. Distance from these routes was calculated.

7. Visitors. Visitor data were obtained for 2001 from the Utah Division of Travel Development (http://travel.utah.gov/countyprofiles.html) and the United States Forest Service (http://www.fs.fed.us/recreation/programs/nvum/reports/year2/ R4_F10_manti_report.doc). Data for the following areas were included: Glen Canyon National Recreation Area, Canyonlands National Park, Natural Bridges Rainbow Bridge, and Hovenweep National Monuments, Monument Valley Tribal Park, Deadhorse Point and Goosenecks State Parks, and Manti LaSal National Forest. Little information is available for visitation to BLM lands, and estimates for the most popular location in San Juan County, Grand Gulch, are an order of magnitude less than any other location. Therefore, no visitation to BLM lands was included. Polygons for each visited area were obtained from a Land Ownership Categories dataset $(1: 100,000)$ from the UAGRC. Visitor numbers were assigned to the centroid of each visited area unless noted below. Visitors to Canyonlands were equally distributed between the two main districts: Needles and Island in the Sky. Visitors to Glen Canyon National Recreation Area were equally distributed amongst the five marinas on Lake Powell. Visitors to Manti LaSal National Forest were equally distributed amongst the three geographically-isolated districts. Density was calculated in annual visitors per square kilometer based on a search radius of 30 kilometers. 
8. Population. Population data were obtained from the United States Census Bureau for Census 2000 (http://www.census.gov). Population values for 14 towns were located using a Town Demographic dataset $(1: 100,000)$ obtained from the UAGRC. Density was calculated in persons per square kilometer based on a search radius of 30 kilometers.

9. Reclassification. All density, distance, slope, and land use grids were reclassified to provide a common scale for multi-criteria analysis. In this scale, 10 represents the greatest impact to the landscape and 1 represents the least impact.

-Population density (persons per square kilometer) was classified by the natural breaks method using 10 classes. Values were assigned as follows: $10 / 3-3.5,9 / 2.5-3,8 / 2-2.5$, $7 / 1.5-2,6 / 1.25-1.5,5 / 1-1.25,4 / .75-1,3 / .5-.75,2 / .25-.5,1 /$ less than .25 .

-Visitor density (annual visitors per square kilometer) was classified by the natural breaks method using 10 classes. Values were assigned as follows: 10/400-500, $9 / 350$ $400,8 / 300-350,7 / 250-300,6 / 200-250,5 / 150-200,4 / 100-150,3 / 50-100,2 / 20$ $50,1 /$ less than 20 .

-Distances to paved roads, gravel roads, and dirt roads (kilometers) were classified separately. Values for paved roads were assigned as follows: $10 / 0-1,8 / 1-2,6 / 2-5,4 /$ 5-10, 2/ 10-20,1/ more than 20. Values for gravel roads were assigned as follows: $10 /$ $0-0.5,8 / 0.5-1,6 / 1-2,4 / 2-5,2 / 5-10,1 /$ more than 10 . Values for dirt roads were assigned as follows: $10 / 0-0.2,8 / 0.2-0.5,6 / 0.5-1,4 / 1-2,2 / 2-5,1 /$ more than 2 .

-Distance to off-highway vehicle routes was classified the same as distance to dirt roads.

-Mineral impact and energy impact densities were classified by quantiles using 10 classes. Values were assigned as follows for minerals: $10 / 1.036-2.852,9 / 0.613-1.036$, $8 / 0.356-0.613,7 / 0.234-0.356,6 / 0.156-0.234,5 / 0.1-0.156,4 / 0.056-0.1,3 / 0.022-$

$.056,2 / 0-0.022,1 / 0$. Values were assigned as follows for energy: $10 / 0.314-0.732,9 /$ $0.232-0.314,8 / 0.177-0.232,7 / 0.134-0.177,6 / 0.1-0.134,5 / 0.066-0.1,4 / 0.037-$ $0.066,3 / 0.015-0.037,2 / 0-0.015,1 / 0$.

-The median of slope (degrees) was classified by natural breaks using 5 classes. Values were assigned as follows: $10 / 0-2.90,7 / 2.90-7.16,5 / 7.16-12.62,3 / 12.62-19.45,1 /$ more than 19.45. LULC was classified as follows: 10- urban, agriculture, water, $5-$ rangeland, 3- forest land, 1- barren land.

10. Multi-criteria Analysis- Distance to Roads and Naturalness. To obtain a measure of the impact of distance from roads, the three reclassified rasters for distance to roads were summed, with equal weight given to each. The two reclassified rasters for median 
of slope and LULC were summed, with equal weight given to each, to obtain a measure of the naturalness of the landscape.

11. Multi-criteria Analysis- Wilderness Characteristics. To determine wilderness characteristics, the reclassified rasters for population density, distance to roads, and slope/land use were summed with equal weight given to each. To obtain the wildness index, all seven rasters were combined with weights distributed as follows: 0.2 for the wilderness characteristics noted above and 0.1 for the multiple-use properties of visitor density, distance to OHV routes, mineral impact density, and energy impact density.

12. Multi-criteria Analysis- Wildness Index. Maps showing surfaces that represent wilderness characteristics and a wildness index were the final product. Although the numbers that represent a continuum of each property are meaningless in and of themselves, they can be used for comparative evaluation. The neighborhood statistics function in spatial analyst was used to calculate the wildness index values for the wilderness proposals from different groups, and these values are shown in the table on the following page. 
WILDNESS CONTINUUM VALUES FOR WILDERNESS PROPOSALS IN SAN JUAN COUNY.

\begin{tabular}{|c|c|c|c|}
\hline Study Unit & $\begin{array}{l}\text { Wilderness } \\
\text { Study Areas }\end{array}$ & $\begin{array}{c}\text { Re-inventory } \\
\text { Study Unit }\end{array}$ & $\begin{array}{l}\text { Citizens' } \mathrm{Re}- \\
\text { inventory Units }\end{array}$ \\
\hline Allen Canyon & - & ---- & 5.49 \\
\hline Arch Canyon & ---- & 3.75 & 4.33 \\
\hline Bridger Jack Mesa & 2.78 & 2.95 & 3.80 \\
\hline Butler Wash & 2.09 & 2.73 & 2.83 \\
\hline Cheesebox Canyon & 3.47 & 3.80 & 3.73 \\
\hline Comb Ridge & $\cdots$ & 3.79 & 4.15 \\
\hline Copper Point & ---- & ---- & 4.84 \\
\hline Cross Canyon & 3.38 & 3.65 & 3.56 \\
\hline Dark Canyon & 2.25 & 2.38 & 2.82 \\
\hline Fish/Owl Canyons & 2.59 & 3.37 & 3.32 \\
\hline Fort Knocker Canyon & ---- & 5.11 & 5.51 \\
\hline Grand Gulch & 2.54 & 2.99 & 3.36 \\
\hline Gravel/Long Canyons & ----- & 3.62 & ---- \\
\hline Hammond Canyon & ---- & $-\cdots$ & 5.35 \\
\hline Harmony Flat & ---- & 3.59 & $-\cdots$ \\
\hline Hart's Point & ---- & 2.85 & 3.80 \\
\hline Indian Creek & 4.23 & 4.30 & 4.18 \\
\hline Mancos Mesa & 2.36 & 2.65 & ---- \\
\hline Monument Canyon & ---- & ---- & 3.70 \\
\hline Mule Canyon & 2.82 & -.-- & $-\cdots--$ \\
\hline Nokai Dome & ----- & 2.96 & 3.51 \\
\hline Red Rock Plateau & $\ldots$ & --- & 3.42 \\
\hline Road Canyon & 2.61 & 3.17 & 3.02 \\
\hline San Juan River & -.--- & 3.55 & 3.95 \\
\hline Shay Mountain & $\ldots$ & ---- & 3.67 \\
\hline Sheep Canyon & & 4.53 & --- \\
\hline Squaw/Papoose & 3.22 & 3.74 & $-\cdots$ \\
\hline Canyons & & & \\
\hline The Tabernacle & ----- & ---- & 4.09 \\
\hline Tin Cup Mesa & $-\cdots$ & -..-- & 3.89 \\
\hline Tuwa Canyon & ---- & ----- & 3.69 \\
\hline Upper Red Canyon & ---- & ---- & 3.66 \\
\hline Mean & 2.54 & 3.14 & 3.77 \\
\hline Standard Deviation & 0.38 & 0.52 & 0.43 \\
\hline
\end{tabular}

Note: The 1999 Citizens' Proposal includes all wilderness study areas and re-inventory study units. 